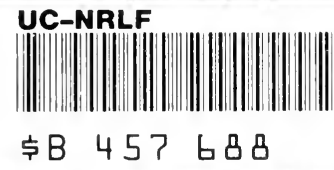



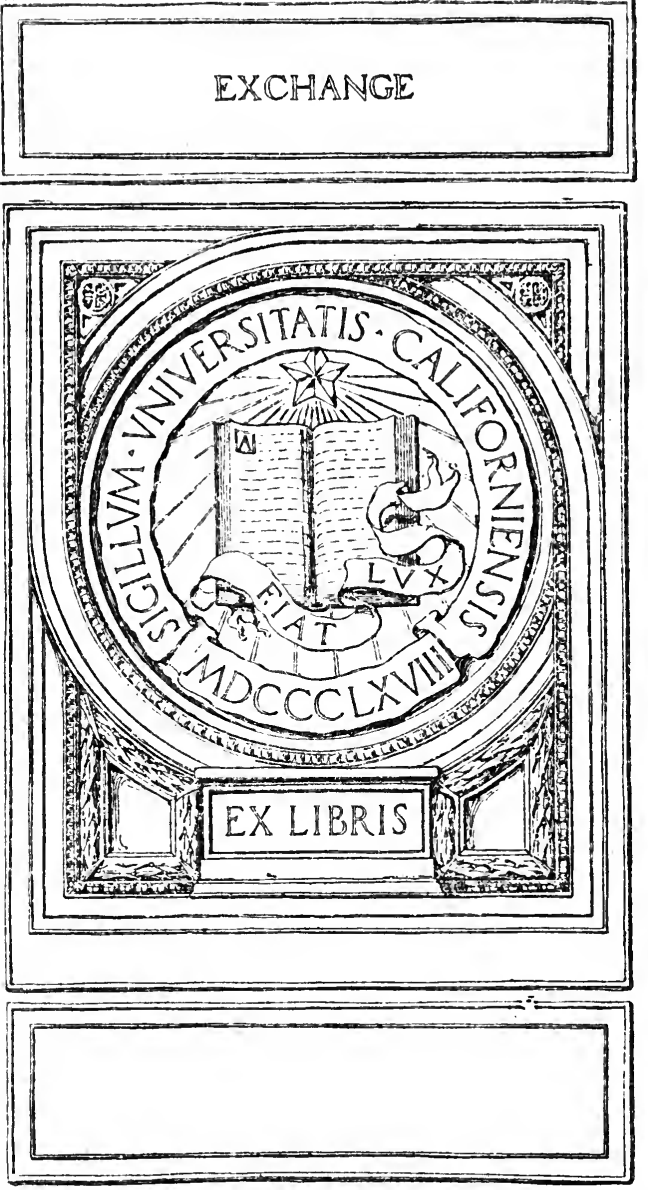



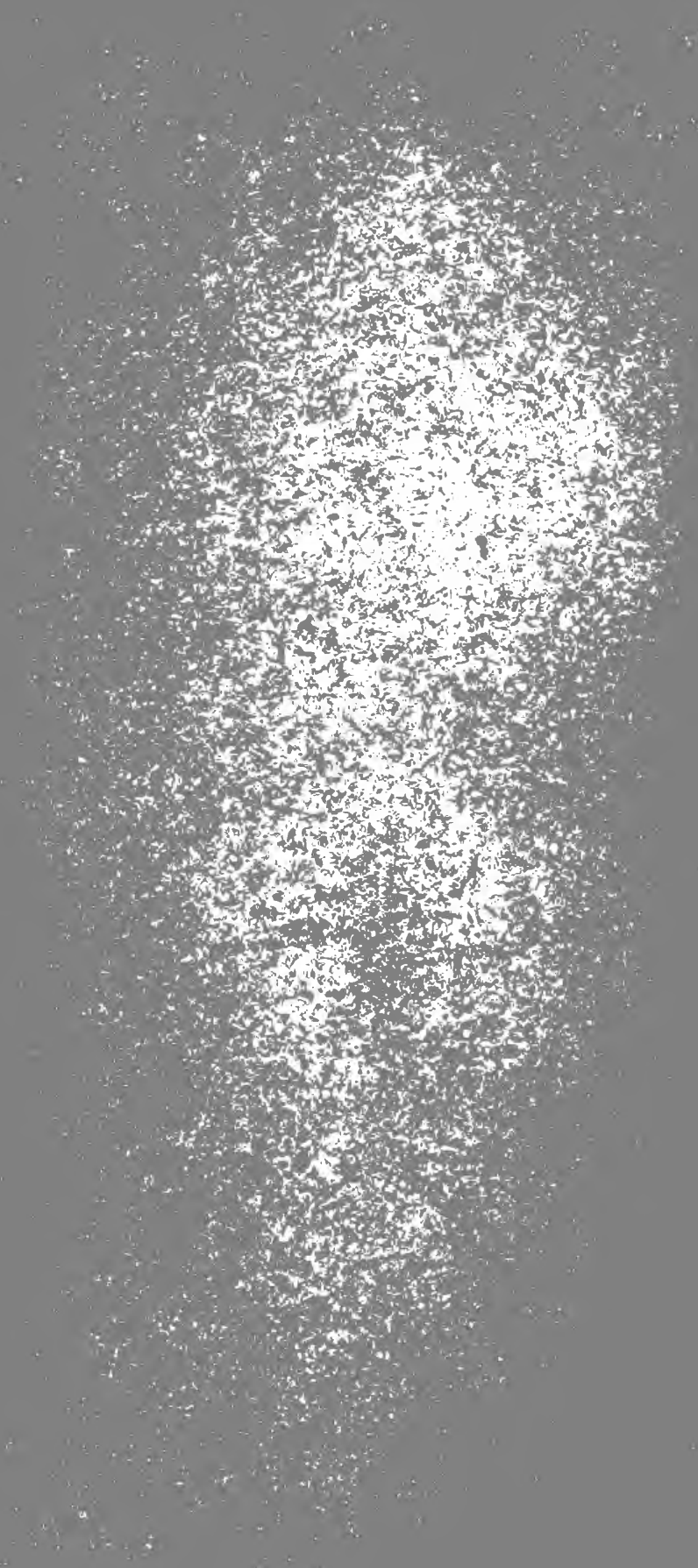




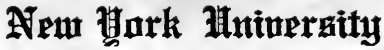

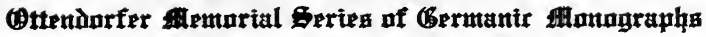
Iin. B

\section{YOUNG GERMANY IN ITS RELATIONS TO BRITAIN}

\author{
JOHN/WHYTE \\ Assistant Professor in New York University
}




$$
\text { a }
$$

Excrontulast 


$$
\begin{aligned}
& \text { PT } 384 \\
& \text { G7W5 }
\end{aligned}
$$

To the Memory

of

Oswald Ottendorfer 


\section{Digitized by the Internet Archive in 2007 with funding from Microsoft Corporation}




\section{PREFACE}

This study, which was accepted as a dissertation for the degree of $\mathrm{Ph} . \mathrm{D}$. at the University of Wisconsin in June 1915, has had the benefit of helpful criticisms by Prof. A. R. Hohlfeld of the University of Wisconsin. I desire to express my gratitude to him. My thanks are also due to Prof. Lawrence A. McLouth, the Secretary of the Ottendorfer Memorial Fellowship Committee, for his kindness to me as Ottendorfer Fellow; to Prof. Adolf Carl von Noé of the University of Chicago and Dr. Lawrence M. Price of the University of California for suggestions; to Prof. Frederick $\mathrm{H}$. Wilkens of New York University for his careful reading of the proof; and to my wife for assistance in the preparation of the manuscript and in reading of the proof. Finally I feel deeply obliged to the authorities of the following libraries for their great help in providing me (at a time when books from Germany were not accessible) with a working library for my study: University of Wisconsin, University of Chicago, Harvard University, Columbia University, Yale University, New York Public Library, Leland Stanford Jr. University and New York University. 



\section{TABLE OF CONTENTS}

Introduction ................................................................... ix

Börne

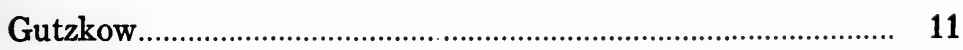

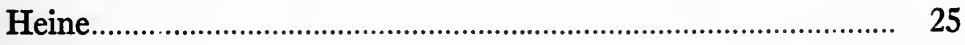

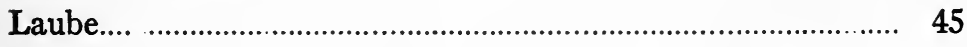

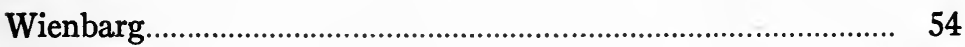

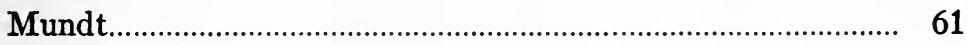

Summary and Conclusion................................................... 75

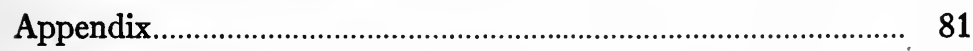

The Periodicals of Young Germany.......................................... 85

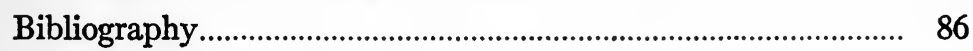





\section{INTRODUCTION}

In the following investigation I have attempted a consideration of the attitude of Young Germany toward Britain. I have included in Young Germany all of the writers who were denominated as members of this literary school (which in point of fact never existed) by the Prussian ministerial decrees of 1835, viz.: Heinrich Heine, Karl Gutzkow, Ludolf Wienbarg, Theodor Mundt and Heinrich Laube. To them I have added one other, Ludwig Börne, a forerunner of the group. The year 1848 has seemed the most natural "terminus ad quem," and in general I have held rather closely to it. The particularly significant years are, however, the years 1830-1840, and the quotations from these years are for the expression of specifically Young German thought of far greater importance than those of the subsequent years to the revolution of 1848. It has seemed best to discuss the attitude of each representative individually. The treatment of the men has been naturally differentiated by the difference of material, but a certain unity has been preserved by holding to the following classification: the attitude of Young Germany 1. toward British Politics, 2. toward British Literature, 3. toward The Briton. 



\section{BÖRNE}

\section{British Politics}

It was from France that Börne drew most of his political inspiration. He had lived in Frankfurt under the French regime and had enjoyed with his coreligionists the benefits of citizenship. That citizenship the reactionaries had withdrawn, and with it had deprived Börne of his official position in the police bureau of that city. And yet, although his family connections reached to the seat of the reaction, Vienna, and although Metternich, quick to value his talent, had offered him a most inviting career, Börne's allegiance to his political convictions remained firm. He never selfishly identified his struggle for liberty with that of his race, nor did the loss of political office furnish him the motive power for his political activity. His was the cause of universal freedom and equality and that cause found a strong support in the political struggles of France. But by the very nature of things he could draw on the French Revolution only sparingly. Börne needed support from contemporary French political life, and he sought this at its source. In 1830 he left Germany to spend the rest of his days in Paris. His chronicle of part of these last years, his "Briefe aus Paris," from 1830 to 1833 , provides us with an interesting commentary on his attitude toward France and serves also as a point of departure for the consideration of his attitude toward Britain.

It was specifically the advent of the younger line of the Bourbons to the throne that had called Börne to Paris and had fired his political zeal anew. He saw in their return the restoration of representative government and he wanted to witness the dawn of a new era. But he was doomed to disappointment. He soon learned that French government was prone to pendulate between republican absolutism and monarchical absolutism. Six months after the July Revolution he writes: "Aber meine Träume von Frankreichs Freiheit sind auch dahin .... Lafayette war es, der die Revolution rein erhalten und vor Anarchie bewahrt, und ihm hat Orleans seine Krone und die Fürsten Europas zu verdanken, dass Frankreich keine Republik geworden. Er hat dem Volk gesagt, es wäre möglich, dass ein König die Freiheit 
liebe, und man hat es ihm geglaubt ... I Ich sehe es hier an den Besten, dass, sobald man zur Macht kommt, man erst das Herz, dann den Kopf verliert, dass man vom Verstande nur soviel übrig behält, als man braucht, das Herz nicht wieder aufkommen zu lassen." 1

Three months later he writes: "Polen, Italien, Belgien, Frankreich, Deutschland, Freiheit, Gleichheit, Einheit, alle diesen schönen Seifenblasen mit ihren Regenbogenfarben-zerplatzt sind sie, der Luftteufel hat sie geholt." And in October of the same year: "Fragen Sie mich, so oft Sie wollen, nach dem Strassenkote; aber fragen Sie mich nie nach der französischen Politik. Es ist ein gar zu schmutziges Ding. Voriges Jahr sagte ich: Der König ist verloren; jetzt sage ich: Frankreich ist verloren."3

Even the abolishment of the French peerage cannot change his feeling of despair over the course of French politics. On the 13th of October he writes: "Diese Woche war wieder sehr reich an Begebenheiten: die Verwerfung der Reform Bill in England, und die abgeschaffte Erblichkeit der Pairs in Frankreich. Dort hat die Aristokratie gesiegt, hier hat sie eine Niederlage erlitten. Es ist eine Compensation, und es wird dabei für die gute Sache nichts gewonnen und nichts verloren. Der Sieg des Adels in England kann dort eine Revolution und die Volksherrschaft zur Folge haben; dagegen kann die Abschaffung der Erblichkeit der Pairs in Frankreich wieder zum Absolutismus führen." 4 These words seem to suggest, if they do not imply, a grim faith in the ultimate triumph of British democracy. Such a conclusion is more fully warranted by Börne's other re erences to politica! Britain, although it must be admitted that they are not numerous. Perhaps it would not be fair to say that their very infrequency is due to that faith, and yet the tacit assumption that Britain typified political liberty may have been one reason why Börne drew political ammunition from France, a country, where the struggle for liberty was being fought with apparently greater intensity, if not with more lasting results. For Britain was for him the land of political liberty par excellence, and in the penumbra of his political vistas British liberty loomed large-an actual achievement

${ }^{1}$ VIII. 154-156. 21. Brief, 26. Dez. 1830.

${ }^{2}$ IX. 117. 47. Brief, 31. März 1831.

${ }^{3}$ IX. 153. 51. Brief, 8. Okt. 1831.

${ }^{4}$ IX. 178. 52. Brief, 13. Okt. 1831. 
of political struggles, a political fact, contrasting markedly with the gropings toward liberty of even France, not to mention Poland, Belgium, Italy and Germany. His condemnation of the Holy Alliance needs no other support than this: "die zwei einzigen freien Staaten der Welt, England und Nord Amerika, sind ihm nicht beigetreten." And in his famous "Denkrede auf Jean Paul" he says: "Jedem Lande ward für jedes trübe Entbehren irgend eine freundliche Vèrgütung. Der Norden ohne Herz hat seine eiserne Kraft; der kränkelnde Süden hat se ne goldene Sonne, das finstere Spanien seinen Glauben; die darbenden Franzosen erquickt der spendende Witz, und Englands Nebel verklärt die Freiheit. Wir hatten Jean Paul . . ."6

He has a hearty contempt for those who cite Britain in support of reactionary policies or who maintain the inapplicability of British democracy to Germany. He quotes an anonymous writer as saying: "Die Pressfreiheit, die seit Jahr und Tag in Deutschland wuchernde Pressireiheit, hat allen den Jammer verschuldet. Sie müsse ausgerottet werden. Censurgesetze genügen nicht, man müsse die Pressfrechen bestrafen wie in-England. Ja, ihr könnt es lesen, England wurde zum Beispiel genommen!"7 And in his article on "Menzel der Franzosenfresser," he finds occasion for the follow.ng comments on von Raumers "England im Jahre 1835": "Herr von Raumer lobt die Tories aus Staatsdienerpflicht; und die Whigs lobt er auch aus Staatsdienerpflicht; denn, wenn er sich den Whigs feindlich gezeigt, hätte er keine Gelegenheit gefunden, das Lager der Feinde seiner Regierung auszuspähen. Nachdem aber Herr von Raumer die Whigs gelobt, wird ihm dennoch bange; er zittert, man möchte in Berlin argwöhnen, er habe die Whigs nicht bloss aus Staatsdienerpflicht gelobt, sondern von Herzen und aus Uebereinstimmung mit ihren Grundsätzen. Er sucht also diesem Argwohn durch die feierlichsten Versicherungen seiner Rechtsgläubigkeit vorzubeugen. So oft er die englische Freiheit lobt, fügt er hinzu: Die Freiheit in England sei alt und aus historischem Boden hervorgewachsen, in Deutschland aber sei das Verhältnis ganz anders. Das ist freilich sehr wahr und natürlich, $\mathrm{d} n \mathrm{n}$ in Deutschland konnte die Freiheit nie

5 VII. 58-59. Fragmente und Aphorismen.

${ }^{6}$ I. 311-312. Denkrede auf Jean Paul, 2. Dez. 1825.

${ }^{7}$ II. 336. Ueber die Beurteilung des Manuscripts aus Süd-Deutschland. 20. Nov. 1820. 
alt und zu Geschichte werden, weil man sie immer schon als Keim und im Entstehen ausrottete."8

Börne is, however, not blind to the fact that after all Britain possessed liberties and not liberty, to use his own distinction. He says: "Wo denn und von wem wurde noch Freiheit gefordert? Nur Freiheiten wurden verlangt und nur diese wurden bewilligt oder versagt. Kein Volk in Europa ist frei. Selbst in der englischen Staatsverfassung wird nicht, wie es sollte sein, die Freiheit von der Herrschaft, sondern die Herrschaft wird von der Freiheit beschränkt; der Herrschaft wird die Primogenitur zuerkannt und die Freiheit wird reichlich appanagirt. Auch das britische Volk hat nur Freiheiten, aber keine Freiheit."9

$\mathrm{He}$ is but little concerned with British foreign relations. Only once does he make mention $o^{-}$them, and then only in passing. Because of their democratic governments he finds Britain and France natural allies,-allied against reactionary Germany, and he prophesies a conflict between these hostile elements. $\mathrm{He}$ writes: "Schreiben Sie mir doch genau und umständlich, ob man bei uns an den Krieg glaubt. Nach den gestrigen Nachrichten hätten Frankreich und England vor einigen Tagen eine Offensiv- und Defensiv-Allianz geschlossen. Es wäre schön, w:nn das wahr wäre; dann wäre es doch endlich einmal dahin gekommen, wohin es früher oder spä er kommen muss, zum strengen Gegensatze der feindlichen Elemente: die Freiheit hier, die Despotie dort-und jetzt schlagt Euch, ich sehe zu."10

\section{BRITISH LiteratURE}

Börne's opinions on English literature are colored largely by his political prepossessions. He gauged his estimate of poets by their political creeds, and the expression of those creeds, direct or inferential, in their works. Thus Goethe was weighed in the balance and was found wanting, and even Schiller, who is popularly acclaimed a patriotic poet, fared badly at his hands. Shakespeare, Milton and Byron are the English poets who best survive his political analyses.

SHAKESPEARE. "M nschen," he writes, "welche Shakespeare und Calderon lieben und begreifen, das sind gefährliche Demo-

${ }^{8}$ VI. 398-399. Menzel der Franzosenfresser, 1837.

${ }^{\circ}$ V. 256-257. Nouvelles lettres provinciales.

${ }^{10}$ VIII. 113. 15. Brief, 3. Dez. 1830. 
kraten, denn von jenen Meistern lernten sie die Natur der göttlichen und menschlichen Dinge klar durch und durch zu schauen und jedes Blendwerk zu erkennen. Die aber, welchen Racine gefällt, sind geborene Diplomaten, und es lässt sich mit ihnen unterhandeln." Al Among his "Fragmente und Aphorismen" we read: "Es hüte sich der junge Dichter, an seinen Werken jene steinerne Ruhe herauszuarbeiten, von welcher Goethe so verlockende Beispiele gab . . . Die Ruhe der Gleichgültigkeit schafft nur Werke, die gleichgültig lassen. Shakespeare und Calderon wurzelten tief, der in der Natur, der im Glauben . . ."12 Börne admires the versatility of Shakespeare's genius, and in a characteristically Young German manner expresses his wonder that Shakespeare, a Briton, could write Hamlet: "Die Welt staunt Shakespeare's Wunderwerke an. Warum? Ist es denn so viel? Man braucht nur Genie zu haben, das andere ist leicht. Shakespeare wählt den Samen der Art, wirft ihn hin, er keimt, sprosst, wächst empor, bringt Blätter und Blüten, und wenn die Früchte kommen, kommt der Dichter wieder und bricht sie. Er hat sich um nichts bekümmert, Luft und Sonne seines Geistes haben Alles getan, und die Art ist sich treu geblieben. Aber den Hamlet staune ich an, Hamlet hat keinen Weg, keine Richtung, keine Art. Man kann ihm nicht nachsehen, ihn nicht zurechtweisen, nicht prüfen. Sich da nie zu vergessen! Immer daran zu denken, dass man an nichts zu denken habe! Ihn Nichts und Alles sein zu lassen! Ihn immer handeln und nichts tun, immer sich bewegen und nie fortkommen $\mathrm{zu}$ lassen! Ihn immer sich als Kreisel drehen lassen, ohne dass er ausweiche! Das war schwer. Und Shakespeare ist ein Britte! Hätte ein Deutscher den Hamlet gemacht, würde ich mich gar nicht darüber wundern. Ein Deutscher brauchte nur eine schöne, leserliche Hand dazu. Er schreibt sich ab, und Hamlet ist fertig." 13

Murron. It. is in connection with his criticisms of Goethe that Börne praises Milton. "Milton vergass über seine Verse die Not seiner Mitbürger nicht, und wirkte für Freiheit und

"IV. 49. Saul-Tragédie en cinq actes, par M. Alexandre Soumet in "Dramaturgische Blätter."

12 VII. 17-18. Fragmente und Aphorismen.

${ }^{13}$ V. 155-116. Hamlet von Shakespeare in "Dramaturgische Blätter" Cf. R. M. Meyer "Gestalten und Probleme" 265-280, Deutschland ist Hamlet. 
Recht. So waren Swift, Byron, so ist Thomas Moore. Wie war, wie ist Goethe? Bürger einer freien Stadt, erinnert er sich nur, dass er Enkel eines Schultheissen ist, der bei der Kaiserkrönung Kammerdienste durfte tun. . . . Nie hat er ein armes Wörtchen für sein Volk gesprochen, er, der früher auf der Höhe seines Ruhmes unantastbar, später im hohen Alter unverletzlich, hätte sagen dürfen, was kein Anderer wagen durfte." 14

Byron. Börne's enthusiasm for Byron knows no bounds. $\mathrm{He}$ finds in him the ideal poet of humanity. After reading Moore's Life of Byron he writes: "Ich muss lachen, wenn die Leute sagen, Byron wäre nur einige und dreissig Jahre alt geworden; er hat tausend Jahre gelebt. Und wenn sie ihn bedauern, dass er so melancholisch gewesen! Ist es Gott nicht auch? Melancholie ist die Freudigkeit Gottes. Kann man froh sein, wenn man liebt? Byron hasste die Menschen, weil er die Menschheit, das Leben, weil er die Ewigkeit liebte. Es gibt keine andere Wahl. Der Schmerz ist das Glück der Selizen. Am meisten lebt, wer am meisten leidet. Keiner ist glücklich, an den Gott nicht denkt, ist es nicht in Liebe, sei es in Zorn; nur an ihn denkt. Ich gäbe alle Freuden meines ganzen Lebens für ein Jahr von Byrons Schmerzen hin." 15

He even claims a spiritual kinship with Byron: "Vielleicht fragen Sie mich verwundert, wie ich Lump dazu komme, mich mit Byron zusammenzustellen? Darauf muss ich Ihnen erzählen, was Sie noch nicht wissen. Als Byrons Genius auf seiner Reise durch das Firmament auf die Erde kam, eine Nacht dort zu verweilen, stieg er zuerst bei mir ab. Aber das Haus gefiel ihm gar nicht, er eilte schnell wieder fort und kehrte in das Hotel Byron ein. Viele Jahre hat mich das geschmerzt, lange hat es mich betrübt, dass ich so wenig geworden, gar nichts erreicht. Aber jetzt ist es vorüber, ich habe es vergessen und lebe zufrieden in meiner Armut. Mein Unglück ist, dass ich im Mittelstande geboren bin, für den ich gar nicht passe. "15

Scotr. And yet Börne was able at times to detach himself from his political attitude. While his criticisms of Goethe and Schiller are wanton concessions to a political bias, he applies criteria of quite another type to Scott, the Tory. In fact his

${ }^{14}$ III. 386. 20. Mai, 1830.

${ }^{15}$ IX. 93. 44. Brief, 20. März 1831. 
judgments of Scott are so diametrically opposed to his usual mode of thought, so startlingly "un Young-German," that one is forced to the conclusion that even Börne was not so consistently democratic as he professed to be. There is nothing particularly incompatible with Young-German thought in his admiration for Scott, but to attribute Scott's greatness to the fact that he was a Tory seems utterly out of accord both with Börne's habit of mind and the aesthetic principles of Young Germany. "Scott ist ein Tory, und wäre er das nicht, wäre er der grosse Dichter nicht. Die wahren Dichter, wie alle grossen Künstler, lieben das Gewordene, das Seiende, das Notwendige, das Unbewegliche, das dem Meissel still hält; sie lieben daher den Zwang, als den Erhalter des Bestehenden. Darum hassen sie das Werdende, das Bewegliche, das Schwankende, das Strebende und dds Widerstrebende, denn sie hassen den Kampf; darum hassen sie die Freiheit. Man sage nicht, Walter Scott wäre unparteiisch. Er ist es freilich, sobald er einmal den Gegenstand der Darstellung gewählt; ihm liebe Verhältnisse und Menschen verschönt er nicht ungebührlich, $\mathrm{ihm}$ widrige verhässlicht er nicht. Aber er ist parteiisch in der Wahl der Gegenstände, und wo er der Freiheit huldigt, da verehrt. er nur den Sieg und die Gewalt, nicht den Kampf und das Recht der Freiheit. . . ."16

And in the following passage we find Börne in the rôle of the academic literary critic, stripped of all his political and politicalliterary criteria. "Es ist ein untrügliches Zeichen, dass ein dramatisches Gedicht, oder ein episches, oder ein Roman, oder ein historisches Werk, misslungen, wenn man daraus die politischen Ansichten des Verfassers erkennt. Shakespeare und Walter Scott haben in ihren Dichtungen mit keinem Worte verraten, ob sie mehr die Freiheit, oder mehr die Herrschaft liebten." 17

German and British Literature. In his frequent excoriations of German literature, Börne finds occasion to cite British literature. In the characteristic vein of the Young German critic he diagnoses the case of German literature and a comparison with British literature provides him with the needed specific.

${ }^{16} \mathrm{~V}$. 240. Coopers Romane, 1825. A review.

${ }^{17}$ IV. 337. Le Corrupteur, par Lemercier. A review in "Dramaturgische Blätter," 1823. These last two opinions are at least five years earlier than the references to Byron, Milton and Goethe, and it may be safe to assume that Börne's political bias was not yet strongly coloring his literary judgments. 
He finds, for example, that Nature has cut the Germans out for thinking and not for writing, "und blieben sie ihrer Bestimmung treu, würden sie ihre Gedanken roh ausführen und sie von Franzosen und Engländern verarbeiten lassen." ${ }_{18} \mathrm{He}$ deplores the lack of action in the German and in German letters: "Der Deutsche liebt Reden, die Rede ist ihm die geliebte Suppe; der Dichter mag etwas Handlung hineinbrocken, aber nicht zu viel, sie muss Platz zum Schwimmen haben. Wir denken gut und reden schlecht, reden viel und tun wenig, tun Manches und vollbringen nichts. Aber unsere Gleichgültigkeit gegen Handlungen entspringt nicht aus unserer Vorliebe für Worte, sondern umgekehrt, unsere Vorliebe für Worte entspringt aus Scheu vor Handlungen. Die keuschen Deutschen wenden ihre Augen weg vor jeder nackten Tat." 19 And "Es gibt nur ein einziges Drama, das dem Deutschen gefällt, ihm angemessen, und doch dabei schön ist, musterhaft und höchst vollendet-Hamlet. Aber ein Shakespeare müsste kommen, es zu dichten, ein Zauberer, der Alles kann."19

The specific is to be found in Börne's review of the "Graf von Essex" (Trauerspiel nach dem Englischen des Banks). "Hier sind nicht Charaktergemälde, wo ein glänzendes Farbenspiel das Auge blendet und reiche Drapperien die falschen Umrisse bedecken, sondern Charakterbildwerke, treu und vollendet der Natur nachgeahmt. Diese Gediegenheit findet sich oft selbst in den untergeordneten dramatischen Werken der Engländer. Das haben sie von dem öffentlichen Leben ihrer geschichtlichen Menschen. Je unfreier ein Volk ist, je romantischer wird seine Poesie."20

The same lack of action he holds responsible for the inferiority of the German to the British and American novel. In a rather paradoxical fashion he says: "Wenn Goethes Grundsatz wahr ist: der Held eines Romanes müsse sich sehr leidend verhalten, müsse sich alles gefallen lassen und dürfe nicht mucksen-warum haben wir keine guten Romane, da wir doch alle geborne Romanhelden sind? Wir haben keine, weil der Grundsatz wahr ist. Um etwas zu erfahren, muss man etwas tun; wir müssen ge hen,

${ }^{18}$ I. 66, Einige Worte über die angekündigten Jahrbücher der wissenschaftlichen Kritik, 1826.

${ }^{19}$ IV. 258-260, Das Trauerspiel in Tyrol. Ein dramatisches Gedicht von Immermann in "Dramaturgische Blätter."

${ }^{20}$ IV. 312, in "Dramaturgische Blätter." 
dass uns etwas begegne. ... Wir haben keine Geschichte, kein Klima, keine Volksgeselligkeit, keinen Markt des Lebens, keinen Heerd des Vaterlandes, keinen Grosshandel, keine Seefahrt, und wir haben-keine Freiheit zu sagen, was wir noch mehr nicht haben. Woher Romane? . . . Die Engländer schreiben Romane, und wir lesen sie."21

"Ja, wenn es bloss die Engländer wären! man kann viel weniger sein als die, und immer noch viel. Dass aber selbst die Amerikaner es uns zuvorgetan, so ein junges Volk, das kaum die schwäbische Reife erlangt, das beschämt, das entmutigt. Washington Irving, Cooper und noch Andere! Wäre Cooper ein ausgezeichneter Künstler, wie Walter Scott es ist, das möchte uns beruhigen. . . . Manche Deutsche kommen ihm gleich an Kunstfertigkeit; er hat nur vor ihnen voraus, dass er ein Amerikaner ist-versteht Ihr? dass er ein Amerikaner ist." ${ }_{21}$

Börne's strictures on French, German and English style furnish an interesting contribution to the aesthetic principles of "Das Junge Deutschland": "Es gibt einen National-Stil und einen Personal-Stil, jenen haben die Franzosen, diesen die Engländer. In Frankreich ist die Geistesbildung monarchisch, darum unterscheiden sich dort die guten von den mittelmässigen Schriftstellern nur im Gedankenreichtume, nicht durch ihren Stil, der bei allen fast gleich ist. In England ist die Geistesbildung republikanisch. Aber in Deutschland leben die Männer der Kunst und Wissenschaft, ob sie zwar figürlich von einer Gelehrtenrepublik sprechen, den Wilden gleich, noch in keiner geselligen Verbindung; darum haben die Schöpfungen ihres Geistes einen Wert, aber keinen Preis-sie haben keinen Stil. "22

The Briton. Börne's descriptions of the Englishman are not numerous and vary but little from the conventional descriptions by Germans. "Die grämlichen Engländer" ${ }^{23}$ he calls them. In a short article, "Das englische Speisehaus," he continues in that vein: "So bist du, Engländer! Du willst allein sein und lassen, du mit deinen eigenen, Jeden mit seinen Launen; du bist ein unausstehlicher Mensch, du bist ein Republikaner." However, he closes his article with these words: "Die Deutschen, welche

${ }^{21}$ V. 235-239, Coopers Romane.

22 VI. 256-257, 6. Dez. 1820.

${ }^{23}$ III. 29, 1822. 
nach Paris kommen, werden gewiss das englische Speisehaus besuchen, es ist der einzige Ort in Frankreich, wo man deutsche Gründlichkeit findet." ${ }^{24}$

English and German. He finds additional instances of a kinship existing between the two peoples, as his account of the translation of his works into English shows: "Die Pariser Briefe hat der Buchhändler hier schon alle verkauft. Sie werden in das Englische übersetzt. Dagegen habe ich nichts. Geist und Sprache der Engländer weiss sich mit allem Deutschen innigst $\mathrm{zu}$ verschmelzen. Aber die französische Uebersetzung, an die man auch denkt, würde ich hintertreiben, wenn es in meiner Gewalt stünde." 25 When a few months later he happens upon an unknown English translation of his works, he says: "Die Uebersetzungen lesen sich sehr schön und viel schöner als das Original. Die englische Sprache eignet sich sehr für diese Art zu schreiben. Sie hat etwas Kräftiges, schwer Treffendes, braun und blau Schlagendes. Jedes Wort ist ein Knotenstock, jede Rede eine Prügelei." ${ }^{26}$

${ }^{24}$ III. $81,85,1822$.

${ }^{25} \mathrm{X} . \quad 68,63$. Brief, 17. Dez. 1831.

${ }^{26}$ XI. 1, 75. Brief, 13. Feb. 1832. 


\section{GUTZKOW}

\section{British Politics}

In his preface to the second edition of "Paris und Frankreich in den Jahren 1834-1874," Gutzkow writes: "Wie nun diese zu verschiedenen Zeiten verfassten Berichte über Paris und Frankreich hier beisammen stehen, mögen sie auch noch den Beweis führen, wie viel Wahrheit an dem landläufigen Urteil der Literaturgeschichten für höhere und mittlere Schulbildung, für Lehrende und Lernende ist, dass die mit dem Namen des "jungen Deutschland" zusammengefassten Schriftsteller eine undeutsche, mit Frankreich buhlende Gesinnung gegeben hätten! Selbst der Herr Professor Dubois- Reymond hat sich als Rektor der Berliner Universität gemüssigt gesehen, noch bei Beginn des Krieges von 1870 diese Anschuldigung vor den Berliner Studenten zu widerholen. Sie mag auf Heinrich Heine, vielleicht selbst auf Ludwig Börne passen, in Betreff meiner ist sie, wie dies mein Buch Jedem beweisen wird, (ich zitiere nur Seite 61, 65, 88, 169 flgg.) eine Verleumdung."1 To these isolated passages from one book there can be added many others from Gutzkow's collected works that amply refute the charge so frequently brought and reiterated.

It is true that Gutzkow seeks with Börne political inspiration from France, but his opinions on France are from the beginning more discriminating and his appeal from French to British politics is not inferential as frequently in Börne, but implicit in his criticism of France. In his "Philosophie der Tat und des Ereignisses" he writes: "Jetzt wird für jede ergreifende Frage der Geschichte Frankreich, scheint es, die Initiative haben. Es schöpft den ersten Schaum der Gärung ab. Es hat die Frage nicht durchgesprochen, nicht zur Reife ausgebildet, schon die kleinste Handhabe, die sich an ihr sozusagen krümmt, ist für Frankreich genug, sie $z u$ ergreifen. Ueber die unumschränkte Monarchie hatten englische Hofphilosophen gründlichere Untersuchungen angestellt, als sich deren in den schmeichlerischen Versen Racines und Boileaus und in den Abhandlungen der Akademieen finden. Doch Frankreich gab die Mode an, welche die grossen und die kleinen Könige

${ }^{1}$ Gutzkow's Gesammelte Werke, VII. Vorwort VI. Written in 1874. 
nachahmten, die Mode des l'état c'est moi. Seither ist Frankreich der Puls des europäischen Staatslebens geworden und das Land der Symptome. Es hat die Bestimmung, in seiner Einseitigkeit immer über das Ziel hinauszugreifen und das in allen seinen Unternehmungen. Und das deshalb, weil diese Unternehmungen nur die Folgen einer bloss aufblitzenden Ueberlegung sind und nicht immer genug positive Grundlagen haben, um eben so weit wieder zurückgetrieben werden zu können, da die Wahrheit bekanntlich zwischen zwei Extremen schwebt. Frankreich hat die Initiative, aber keinen seiner Anträge und Prozesse wird es bis mehr als zur Hälfte durchsetzen und gewinnen.

Die für die Geschichte reflektive Nation ist die englische. Fast alle Ideen, die in der neuen Geschichte Epoche gemacht haben, waren fünfzig oder hundert Jahre vor ihrem tatsächlichen Ausbruche schon in England Gegenstand der gründlichsten Debatte. Die englische Debatte hat immer etwas für alle Nationen Anwendbares. Die französische nicht. Der Kampf der Parlamente und des Jansenismus gegen die Regentschaft ist eine Debatte, die den Ausbruch der Revolution erleichterte, ging aber für die Zukunft der Ereignisse verloren. Weit weniger die Hautoberfläche reizend, weit systematischer war die Entwicklung des öffentlichen Lebens in England. England wird jeder in Frankreich aufblitzenden Idee eine Tatsache seiner Geschichte als Spiegel vorhalten, und in dem Stolz, entweder schon Alles selbst erlebt zu haben, oder Nichts ohne eigenen Antrieb beginnen zu wollen, der französischen Initiative Widerpart halten. Ein schmaler Streifen Wassers trennt zwei Länder, die ganz entgegengesetzten Beruf haben. Die Praxis, die Erfahrung und die besonnene Ueberlegung kann hier in die Theorie, in die Jugend und den sorglosen Enthusiasmus mit einem Fernrohr hinübersehen." 2

Britain is thus for him also, the classic land of liberty. With Börne he cites Britain's failure to become a member of the Holy Alliance,_- "der das einzig freie Land Europas, England, nicht beitrat."3 And ... "Man muss es England nachsagen, dass es unfähig ist, aus seinem Schosse Sophismen wie die hier widerlegten, zu gebären. Nur Länder, die nie wahre Freiheit genossen haben, Frankreich und Deutschland, scheinen bestimmt zu sein, solche

${ }^{2}$ XII. Philosophie der Tat und des Ereignisses, 131-132, 1835.

${ }^{3}$ XII. Börne's Leben, 291, 1839. 
Grillen zu fangen, die nur aus stickiger Luft entstehen oder aus einem unverantwortlichen Hange zum Servilismus."4

When the British government falls into the hands of the Tories, Gutzkow maintains his faith in the ultimate triumph of British democracy: "Glückliche Fahrt für Robert Peel! Aber auch Glück dem englischen Volke! Denn was ist der Sieg des Torysmus Anderes, als eine Chance des Fortschrittes, sich zusammenzunehmen, als ein Signalruf für die zerstreuten Parteien, welche in ihrer Liebe zum Volke nicht einig werden konnten?"5 Contrast this with his words on France in "Frankreich im Jahre 1835": "Nie wird es dahinkommen, dass in Frankreich an die Stelle des Leichtsinns und der Oberflächlichkeit, sowohl bei Regierten und bei Regierenden, Ernst und würdiger Eifer tritt. . . ."6 "Ja die Freiheit wird dieses Land noch gänzlich verlassen."7

In the conclusion of a chapter on "Die natürlichen Voraussetzungen der Geschichte" in his "Philosophie der Tat und des Ereignisses" he points the course for Germany: "Aus Deutschlands jetziger noch junger Verfassung ein besonderes Moment für die Geschichte $\mathrm{zu}$ entwickeln, ist unmöglich. Doch glaube ich, dass Deutschland aus seinen eigenen Mitteln keine Hypothese mehr aufstellt, sondern dass es bestimmt ist, alles historisch Solide und Praktische von England zu entlehnen."

In "Die Zeitgenossen" Gutzkow reinforces these conclusions. Germany, he says, must look to England for a solution of her political problems. The political progress of France was the result of violent revolutions, while in England political progress had come from the slow, steady application of political principles. Unfortunately the insularity of the Briton had precluded the transference of his political ideas to the continent, and political progress on the continent, instead of being under the constellation of England, had issued from France and French revolutions,

${ }^{4}$ VIII. Säkularbilder, 345. 1837 the year in which Bulwers Zeitgenossen appeared. Die Zeitgenossen II, 81.

${ }^{5}$ IX. Oeffentliche Charaktere. (Wellington 83) 1835.

- VII. Frankreich im Jahre 1834, 3.

${ }^{7}$ VII. Frankreich im Jahre 1834, 5.

${ }^{8}$ XII. Philosophie der Tat und des Ereignisses, 135. 1835. 
whose motivating ideas were after all only plagiarisms from England. "England besass aber nie die Fähigkeit sich mitzuteilen."

Gutzkow supports his propaganda for the introduction of British political institutions by drawing an analogy from the history of German literature. "Die Literatur des vorigen Jahrhunderts ging zu Anfang von den Franzosen aus, wurde dann von den Engländern erobert und von den Deutschen auf eine Höhe gebracht, die Frankreich und England nur noch immer ahnen, und freilich an uns, die wir von jener Höhe längst herabgestiegen sind, nicht begreifen können. . . . Könnte man, wenn man einmal annehmen muss, dass an die Stelle der Literatur jetzt die Politik getreten ist, nicht diesen ganzen Verlauf auch auf unsere Zeit anwenden? Wir befinden uns gegenwärtig noch wie im vorigen Jahrhundert, in der unmittelbaren Anhänglichkeit von französischen Vorstellungen." "9

Gutzkow calls upon German publicists to join in preparing the soil for the introduction of British political ideas: "Geben wir auf England Acht." - 9

Apart from the revolutionary character of French political progress, Gutzkow adduces other reasons for preferring British politics to French politics. He calls attention not only to the virtues of moderation "des so beliebten Musterstaates," but also to the constitutional character of the British government with its retention of a monarchy and an aristocracy. The superimposition of British political ideas on Germany would in Gutzkows opinion involve nothing violently revolutionary: "Mit einem Wort, es ist immer die Monarchie, die erhalten werden soll, es ist die Freiheit, die nur herrschen soll als Gesetz; es ist immer Aristokratie erforderlich, um das Gesetz in der Glorie seiner Souveränität erscheinen zu machen; der Staat soll nicht untergraben, sondern nur auf die rechten Grundlagen gebaut werden. Diese ächte Verschmelzung von Freiheit und Gesetz, von Menschenurrecht und politischem Vorrecht soll, wie sie sich in England findet, den Lauf um die Welt machen. König und Volk, beide sollen unverletzbar und heilig in ihrem Bereiche sein."9

Gutzkow comments frequently and intimately on British government and on contemporary British politics. He vigorously proclaims the superiority of the British constitution over that of

'Die Zeitgenossen, pages 399-413. Written in 1837. Published 1838. 
the French. "Die englische Verfassung hat grosse Fehler; allein sie hat ein volkstümliches Element in sich; das Haus der Gemeinen temperiert nicht bloss die Gewalt der Minister, sondern auch die Uebergewalt des Privilegiums. Kein englischer König würde glauben, so ungestraft seine Finger in die Maschine des Staates stecken zu dürfen, wie dies Louis Philippe tut. Er würde immer fürchten, nicht etwa vom Volk dafür heimgesucht zu werden, oder etwa eine Revolution zu veranlassen, sondern nur ganz einfach sich der Beschämung auszusetzen, keine Minister mehr zu bekommen. Welcher englische Staatsmann besässe einen solchen zynischen und gewissenlosen Ehrgeiz, dass er ein Portefeuille übernähme, in welchem sich keine Gewalt befindet? Welcher englische Staatsmann dürfte es wagen, sich so blosszustellen, wie es die Doctrinairs mit der Freilassung des Prinzen Louis Bonaparte und der Spionage des Conseil in der Schweiz 1837 taten? Wellington, Grey, Peel, wer von Euch würde den Schimpf ertragen, dass Ihr einen Brief aus der Tasche zöget, welchen der Präfect des königlichen Palastes geschrieben, Herr von Montavilet, und öffentlich den Repräsentanten der Nation vorlesen müsstet: "Ich habe die Ehre, Ihnen anzuzeigen, dass die Affaire des Conseil mit der persönlichen Sicherheit des Königs zusammenhängt. Die Kammer weiss nichts, die Minister wissen nichts Die Kammer schweigt, die Minister schweigen, und Frankreich kehrt zur Tagesordnung zurück." 10 Such proceedings Gutzkow finds the order of the day in Germany; even in the constitutional states the diets and the ministry are absolutely subservient to the monarch: "In Deutschland finden diese Anomalieen des ständischen Wesens alle Tage statt. Von jenen schattenartigen Provinzialständen rede ich nicht; selbst in den wirklich konstitutionellen Staaten hat noch keine Kammer, kein Ministerium einem Fürsten das politische System, das er einzuhalten hat, diktieren können."10

Gutzkow's criticisms of British institutions are directed mainly at British criminal procedure. He praises what Howard and his followers have done for the amelioration of prison conditions, but he speaks of "die drakonische Strenge" of criminal law in England and adds a little later: "Oft habe ich darüber nachgedacht, ob es nicht eine weise Einrichtung jenes Geistes ist, der in unseren Schicksalen waltet und Völkern und Ländern das Mass ihrer

${ }^{10}$ VIII. Säkularbilder, 203. Die Zeitgenossen I, 302. 
Besitztümer und Entbehrungen zumisst, dass gerade England, das einzige Land, wo in Europa wahre politische Freiheit herrscht, im Besitz einer Gesetzgebung sein muss, die hinter den Fortschritten, die seit Jahrhunderten der menschliche Geist gemacht hat, weit zurück ist "11

In an essay in which he discusses the possible forms of a German federation, he frequently supports his arguments by references to Britain. Thus for example with respect to a monarchy in Germany he says: "In England erträgt man Aenderungen des Systems und bleibt dabei ein guter und ehrlicher Monarchist; aber in Deutschland, wo man bei jeder kleinen Staatsaktion hinten auch sogleich die Hand des Fürsten sieht und über die persönliche Gesinnung und Meinung des Hofes durchaus keinen Zweifel haben kann, in Deutschland begräbt ein Sturm wie dieser letzte wenigstens unsere winzige Vertretung des grossen und ehrwürdigen Begriffs der Monarchie für immer. Denn man kann monarchisch gesinnt und doch überzeugt sein, dass die deutsche Zersplitterung der Fürstengewalt, dieser Rest der Feudalzeit, dem monarchischen Begriff mehr schadet als nutzt " 12

As an antidote for German particularism he advocates French centralization, although he finds it ridiculous in many of its results. His comments show why he cannot invoke Britain for a corrective: "Die Zentralisation ist das einzige Mittel gegen jenen Lokalegoismus, an welchem in Deutschland Alles kränkelt, ja, an dem auch in England Alles kränkeln würde, wenn nicht England gegen den Egoismus der Gemeinden den gewaltigen Gegendruck des Egoismus der Nation hätte, das wuchernde Schlinggewächs der Privilegien dort nicht vom Baume der Freiheit überragt würde "13

These are a few representative excerpts from Gutzkow. His range of interest and information has given him opportunity for many other excursions into British political history and British political conditions, but their inclusion would necessitate many pages of comparatively unimportant opinions. The tone of most of them is very favorable and in the comparisons which he institutes, Germany, France and even America suffer. There might be added, however, as an interesting commentary on Gutzkow, him-

${ }^{11}$ VIII. Säkularbilder, 348 .

${ }^{12} \mathrm{X} . \quad$ Zur Geschichte unserer Zeit, 228. 1848.

${ }^{13}$ VII. Briefe aus Paris. 178, 1842. 
self one of the chief sufferers of the German censorship, his verdict on the freedom of the press in England. "In England ist die Presse vollkommen frei. Ehre und Ruf, nichts schont sie; das leichte Gerücht stempelt sie zur gewissesten Wahrheit. Sie hält die Lüge für die geschickteste Waffe, um den Gegner zu vernichten. Die englische Presse ist so zügellos, wie die englische Armee, wenn diese nicht mehr unter der Peitsche steht. Ich spreche es den Engländern nach, dass es nun einmal im Charakter dieses Volks liege, einer unausrottbaren Zügellosigkeit nicht anders Herr werden zu können. Auch in der englischen Presse herrscht nicht der Gentleman. Da ist der Firnis der gesellschaftlichen Bildung abgewischt, die gewalttätigste Derbheit die willkommenste Sprache. Besonnene Gesetzgeber haben über die Abschaffung dieses Uebels nachgedacht. Allein die Kollision mit dem politischen und parteiischen Teil der Presse hinderte sie immer, der Presse einige vernünftige Schranken $\mathrm{zu}$ ziehen.... Es ist eigen mit der Pressfreiheit; sie ist für jeden Einzelnen zuweilen ein grosses Unglück und doch für die Gesamtheit ein grosses Glück." 14 His proposal for a censorship smacks of the visionariness to which too many of the Young Germans were given, particularly as with the years they began to recede from their radical positions. "Es muss eine Zensur im höhern Sinne des Wortes geben, eine Superiorität des Staates über die Presse; denn woher will man anders das Strafrecht des Staates leiten, wenn es sich um Pressvergehen handelt? Die Zensur muss eben darin bestehen, dass sich der Staat seines innigen Zusammenhanges mit der Wissenschaft und Ideenwelt bewusst wird, dass er nicht nur bereit ist, jede Eroberung im Reiche der Gedanken, jede gereifte Frucht auf dem Felde selbst der vom Wind bewegten Debatte anzuerkennen und sich zu eigen zu machen, sondern auch Eroberungen dieser Art zu unterstützen, und die Reife in der Saat wenigstens durch Milde und Sonnenschein zu befördern. " 15

\section{BRITISH LITERATURE}

Gutzkow's political bias was not strong enough to warp his judgments on literature. A subscriber to the aesthetic principles of Young Germany, he lamented with his compatriots, Goethe's political indifference, but he was far from calling his genius into

${ }^{14}$ VIII. Säkularbilder, 445. Die Zeitgenossen II, 310.

15 VIII. Säkularbilder, 445-446. Die Zeitgenossen II, 317. 
question. One, though not always the dominant criterion that he advanced, was the intimate contact of literature with life, and it is in this connection that he cites Britain and British literature. $\mathrm{He}$ deplores the lack of interaction between life and literature in both France and Germany and says: "Bei den Engländern findet noch so ziemlich $z$ wischen Leben und Literatur ein Gleichgewicht statt." ${ }_{16}$ He elaborates Börne's contention that the only atmosphere in which a dramatic talent can thrive, is political freedom, and he adduces additional support for Börne's assertion that the British drama derives its strength from British liberty: "Wo kein öffentliches Leben herrscht, muss nicht nur der dichterische Ausdruck seiner natürlichen Kraft beraubt werden, sondern die Gestalten werden auch nicht den freien Geist ureigenster Persönlichkeit athmen; Rücksichten entnerven die Sprache und lassen die Malerei des Lebens sich nur in dämmernden Andeutungen ergehen. England, so gross durch seine dem einzelnen gestattete politische Freiheit, hat darum nie aufgehört, selbst beim unleugbar dort herrschenden Verfall der dramatischen Kunst, ab und $z u$ Stücke zu zeitigen, die eine feine Charakteristik, tiefe Menschenkenntnis verraten; im vorigen Jahrhundert massenhaft. Börne bemerkt dies bei Gelegenheit des Cumberlandschen Juden und des Grafen von Essex. Ein Engländer kann in so nebelhafte Allgemeinheiten und unmögliche Spezialitäten, wie sie die deutsche Bühne schildert, nie geraten, weil ihn der freie Gebrauch seines Daseins das menschliche Dasein überhaupt richtiger verstehen lehrt. In neuester Zeit ist das Drama in England durch den vorherrschend epischlyrischen Charakter seiner Dichter gesunken, und dennoch, was wir von englischen Stücken übersetzen, zeichnet sich immer noch durch eine klare und täuschende Lebenswahrheit aus, so die Gebrüder Foster, der Bucklige, Bulwers neueste Dramen und manches Andere, dessen die Uebersetzer sich nur allzurasch bemächtigen. . . . Unsere Dramen bewegen sich meist in einer fiktiven Welt, sogar die Sitten und Charaktere der Lustspiele sind nicht echt und wahrhaft aus dem Leben gegriffen. . . Unser Theater kann nicht aufblühen, so lange ihm die Lebensluft der Freiheit fehlt." ${ }_{17}$

${ }^{16}$ VIII. Säkularbilder, 6.

${ }^{17}$ XII. Börne's Leben, 300-301, 1839.

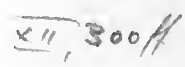




\section{Byron and Shelley}

Byron and Shelley typify for Gutzkow the new literature, that literature that is born from the wedlock with life. "Man täusche sich nicht; die Einsichten über das Verhältnis der Kunst zum Leben kamen spät. . . . Die beiden Jahrhunderte lagen noch in ihren Widersprüchen so wenig grell vor Aller Augen, dass sich sowohl in Frankreich wie in Deutschland die Zeitpoesie der alten herkömmlichen Formen bediente und um neue Dinge einstweilen noch immer abgetragene Gewänder schlug, Frankreich die mythologische Garderobe des Parnass, Goethe schon wieder seine Promethastereien in Epimenides. Kurz dasjenige, was man die neue Poesie nennen kann, die Schule Byrons, die französische Neuromantik mit ihrem Odenschwung, nebst den deutschen Bestrebungen, das Gegenwärtige, Lebendige, in den Zeitgenossen Wurzelnde wiederzugeben, diese Revolution der aesthetischen Begriffe und Ideale beginnt erst mit dem Tode Napoleons."18 And "Es ist überdies seltsam, Goethe erwähnte die Weltliteratur, um der sogenannten zeitgemässen Poesie zu entfliehen, und derjenige Name, an welchen er die Weltliteratur anknüpfte, war die höchste Potenzierung der modernen Bildung: Lord Byron."19 And yet in spite of this realization that Byron was the incarnation of all that Young Germany stood for, Gutzkow did not join in the general apotheosis of Byron that united Goethe and his literary enemies.

It seems but natural that the persecuted author of "Wally" should feel a kinship with Shelley. He includes him, the only English poet so included, in his "Oeffentliche Charaktere" in his collected works. The essay is taken, however, from Gutzkow's "Götter, Helden, Don Quixote," (Abstimmungen zur Beurteilung der literarischen Epoche) and in this collection of essays it forms the first under the heading "Götter." Gutzkow writes feelingly of Shelley's genius and of his tribulations. "Wenn irgend das Leben eines modernen Dichters-das war Shelley recht eigentlichdie Stellung des originellen Gedankens und der schöpferischen Phantasie unserm schroffen, egoistischen und an Vorurteilen haftenden Zeitalter gegenüber vergegenwärtigen kann, so ist es das Leben Shelley's. Er war ein Sohn der Zeit, wie keiner, und

${ }^{18}$ XII. Ueber Goethe im Wendepunkte zweier Jahrhunderte, 73, 1835.

${ }^{19}$ XII. Ueber Goethe im Wendepunkte zweier Jahrhunderte, 82, 1835. 
seine Mutter, gerade unser materielles, leichtsinniges Jahrhundert stiess ihn von sich. Wie Keiner trug er den Fluch einer Epoche, die nur von Gärungen und halben Ahnungen bezeichnet wird, den Fluch des Missverständnisses und einer dem Neide und der Intrigue so leichten Entstellung edelster Träume und Absichten. Er konnte sich nicht verteidigen." 20 Gutzkow attempts an appreciation of Shelley's poetry, but after a page of similes and metaphors descriptive of Shelley's genius, he cautiously adds: "Ich verstehe nicht Englisch genug, um meiner Charakteristik der Shelley'schen Poesie Vollständigkeit zu geben. "21

\section{British Literature}

Gutzkow's knowledge of British literature as revealed in his works is fairly general, but his criticisms of British writers, with the exception of Byron and Shelley, add nothing to Young German literary standards, nor are they important enough to be included for their own sake. A specific instance of a literary debt in one sense is Gutzkow's "Säkularbilder," which first appeared under the title "Bulwer's Zeitgenossen," "wobei ich mir Bulwer's 'England und die Engländer' zum Muster nahm." 22

Gutzkow's preface to the third edition of his Säkularbilder Vol. VIII reviews the genesis and evolution of the work, throwing an interesting light on his relation to Bulwer and to Britain. "Der Verfasser trug sich mehre Jahre mit der Idee eines Werkes, das den Versuch machen sollte, ein Gesamtbild unsres Jahrhunderts nach seinen vorzüglichsten Lebensäusserungen und Gedankenrichtungen zu geben. Anfangs 1837 hielt er sich für befähigt, an diese schwere Aufgabe $z u$ gehen. Doch mit seinem Namen begleitet würde eine solche, gerade mit der Zeit und ihren Tenden-

${ }^{20}$ IX. Oeffentliche Charaktere, Shelley, 204, 1837.

${ }^{21}$ IX. Oeffentliche Charaktere, Shelley, 206, 1837.

${ }^{22}$ VIII. Säkularbilder, Vorwort (3. Auflage) VI-VIII. Written in 1875. In this preface Gutzkow makes no mention of "Die Zeitgenossen. Die zweite unveränderte Ausgabe" (1842), to which I have had access. The additional material that "Die Zeitgenossen" provides for a discussion of Gutzkow and England I have used on preceding pages of this chapter. I have not attempted a close analysis of the changes that Gutzkow effected in his successive editions. Nor have I felt at this place the necessity of a detailed comparison of the similarities and differences in Bulwer's "England and the English" and Gutzkow's "Bulwer's Zeitgenossen,". . . particularly since I have learned tht Dr. Lawrence M. Price of the University of California is contemplating a study of the influence of Bulwer on Gutzkow. 
zen sich beschäftigende Schrift und ohnehin bei seiner ihm zur andern Natur gewordenen liberalen Auffassung in ganz Preussen verboten worden sein, und diejenigen deutschen Regierungen, welche gewohnt waren, alles Preussische nachzuahmen, würden dies Verbot auch für die Kreise der ihnen gehörenden Botmässigkeit ausgedehnt haben. Unter diesen Umständen entschloss sich der Verfasser, dem es um die Grundsätze seines Buches mehr zu tun war, als um seine Person, auf den Titel desselben den Namen Bulwer's zu setzen. Nachstehendes Buch erschien unter der Firma: Bulwer's Zeitgenossen.

Die schützende Devise eines ausländischen Schriftstellers durfte freilich kein blosses Aushängeschild sein. Die Verfolger würden ein Titelblatt leicht durchschaut haben. Ich musste daher bedacht sein, dem Buche, das in zwölf Heften erschien, auch eine englische Färbung zu geben, wobei ich mir Bulwers "England und die Engländer" zum Muster nahm. Von dem Vorwurf, dass ich das Publikum hätte täuschen wollen, glaube ich dadurch losgesprochen zu sein, dass die Pseudo-Autorschaft sofort erkannt und von mir nirgends in Abrede gestellt wurde.

In einer neuen Ausgabe, die 1846 von diesem Buche, das ich dann "Säkularbilder" nannte, erschien, habe ich schon das englische Gewand abzustreifen gesucht. Die Aufgabe war nicht leicht.: Ich hatte versucht, für die beispielsweise gegebenen englischen Charaktere, die ich zur Belebung des Raisonnements erfand, deutsche aufzustellen. Doch liess sich die bevorzugte Anknüpfung der Erörterungen an England nicht durchaus unterdrücken; wodurch ich mich indessen weniger beunruhigt fühle; denn Englands gesellschaftliche und politische Zustände sind der Art, dass Deutschland gut tut, seine eigenen Bestrebungen vorzugsweise mit jener Form, wie sich Aehnliches in England ausnimmt, zu vergleichen. Mein Standpunkt, den ich gleichsam von London aus nahm, wurde ein universaler.

Vom Jahre 1848 an waren die Umgestaltungen der Zeit zu gross, um jeder derselben in diesem letzten Neudruck Rechnung zu tragen. Hier und da weisen Anmerkungen unter dem Text auf die Gegenwart hin.",22

\section{British Philosophy AND Historiography}

Gutzkow's attitude toward British philosophy and historiography, contributory as it is to the characterization of the Briton 
and to the question of Young German philosophy and aesthetics, merits a few words. Gutzkow emphasizes with Wienbarg, the founder of the aesthetics of Young Germany, the watchwords, "Tat," "Ereignis," "Charakter." For example: "Die Geschichte beginnt nicht mit dem ersten Menschen, sondern mit dem ersten Charakter. Ihr Signal ist die erste Tat. . . "'23 The British treatment of philosophy and history corresponds more nearly to Gutzkow's demands than does the German treatment which so frequently has been characterized by "Schematismus" and "Konstruktion." "Englische Philosophie und Geschichtsschreibung haben bis heute den anthropologischen Charakter festgehalten. Der Engländer, auch am menschlichen Körper der geschickteste Anatom, seziert gern die kleinsten Fasern der menschlichen Seele. .. . Die Engländer haben demnach eine nationale Antipathie gegen universal historischen Schematismus. Sie suchen nur Eines in der Geschichte, den Menschen, nicht wie die Franzosen den Bürger, oder wie die Deutschen den Gott. Man nehme die Conflikte, in welche Gibbon mit dem Christentum geriet! Weit entfernt, in dem Verfall des römischen Staates nach deutschen Anschauungen das Abblühen einer überreifen Erscheinung, die nur die Stufe zu einer andern gewesen wäre, zu sehen, weit entfernt, den Untergang der Römer als eine universalhistorische Notwendigkeit zu betrachten, die ihnen vom Christentume nach göttlichem Ratschlusse wäre auferlegt worden, zerlegt Gibbon den Verfall in seine einzelnen Ursachen, in die Missgriffe der Regierungen, die Laster und Tyranneien der Kaiser, die Sittenlosigkeit und den Luxus der Untertanen, und gibt dabei dem Christentum eine Stellung weder höher noch tiefer als irgend einer dieser mit vielbewunderten Stilguirlanden umwundenen historischen Gruppen." 24

The debt of philosophy and historiography to Britain he expresses in these words: "Die Philosophie musste sich von der Scholastik, die Geschichtsschreibung von der Chronik freimachen, ehe jene auf diese angewandt wurde. Wie in allen Punkten, wo Ernst, Tüchtigkeit und Charakter auf die Beförderung menschlicher Entwicklungen das Meiste beitrugen, ging auch hier England

${ }^{23}$ XII. Philosophie der Tat und des Ereignisses, 114, 1835.

${ }^{24}$ XII. Philosophie der Tat und des Ereignisses, 97-98, 1835. 
mit seinem Beispiele voran. Philosophie und Historie verdanken beide den Engländern ihre Grundlegungen." 25

\section{THE BRITON}

This last citation with its reference to the "Ernst, Tüchtigkeit und Charakter" of the Briton may be used as one of Gutzkow's opinions of the British character. Gutzkow analyzes the Briton very closely in a comparison of John Bull and Brother Jonathan. Although the British characteristics are set off in every instance against American characteristics and are hence somewhat licking in pertinency from a German point of departure, the analysis gives us the most complete estimate of the Briton that Gutzkow has attempted. "England und Nordamerika sind sich so verwandt, und doch gibt es keinen Kontrast, der entschiedener wäre als John Bull und Jonathan. . . . John Bull ist beschränkter als Jonathan, was gewisse Kenntnisse anbelangt. Jener wird nicht wissen, wo Charlestown liegt, dieser aber gewiss, wo Perth. Doch hat John Bull eine grössere Geläufigkeit im Denken. Er ist subjektiver, launiger, hat bessere Einfälle als Jonathan, der eben gar keine hat.... Der freie Amerikaner scheint weit mehr Kopfhänger zu sein, als der feudale John Bull, der so grosse Steuern zahlen muss. Seine Schadloshaltung dafür besteht in der Anwendung seines Mutterwitzes, dem er eine Essigschärfe von ätzender Kraft zu geben weiss. John Bull tadelt Alles was nicht von ihm ausgeht, er tadelt, was er nicht selbst ist, und wird so lange mit der Opposition stimmen, bis er selbst auf die Ministerbank rückt. ... Das Raisonnieren, das Besserwissen, die Unverschämtheit John Bulls ist nicht seine beste Seite, er ist darin ein weit grösserer "Philister" als Jonathan. . . . John Bull kann die Regierung nicht oft genug sehen, Jonathan fühlt sich von ihr incommodiert, er ist in dieser Rücksicht ein freier Mann, er kennt weder die knechtische Furcht vor der Polizei, noch den kleinen Spott, den die Polizei bei uns sogar von den ehrlichen Leuten ertragen muss. . . . John Bull handelt in der Regel leichtsinnig und ohne Konsequenz. Der Instinkt und die Leidenschaft reissen ihn zu jeder Unternehmung fort. Grundsätze, dauernde Maximen hat er wenig. Auch Jonathan hat nur Erfahrungsgrundsätze. . . .'26 For the purposes of further comparison Gutzkow transfers both to a desert island and finds that Jonathan

${ }^{25}$ XII. Philosophie der Tat und des Ereignisses, 96, 1835.

${ }^{26}$ VIII. Säkularbilder, 98-99. 
behaves himself more respectably.... "mit einem Worte, Jonathan übertrifft ihn an Hoffnung, Charakter und praktischer Lebensphilosophie."

"Dagegen hat Jonathan einige andere politische Fehler für sich voraus. Er ist prahlerisch, effekthaschend, schneidet gern auf; er vergrössert sein Glück und verkleinert sein Unglück, das heisst, er versteht gut lügen und heucheln. John Bull-warum sollte der es nicht auch können! Allein Jonathan übertrifft ihn. Jonathan übertrifft ihn sogar darin, dass er nicht bloss Heuchler gegen Andere, sondern auch gegen sich selbst sein kann. Das kann John Bull nicht. Gegen sich selbst ist er aufrichtig, sich selbst gesteht er, wie's mit ihm beschaffen ist, er faltet keine andächtigen Mienen und hängt den Kopf nicht wie Jonathan, der sich selbst einen Sünder nennt, aber nur deshalb, weil er durch eine kleine Aufrichtigkeit gegen den Himmel gegen die Erde desto versteckter sein zu dürfen glaubt.

Jonathan hält sich für den ersten Staatsmann in der Welt. Er sagt und widerholt es beständig: Wir leben in einem freien Land! Krieg, Marine, Verfassung, Wissenschaft. Alles ist bei ihm gleich unübertrefflich. Er verachtet andere Nationen mehr, als der Patriotismus entschuldigen dürfte." 27

\section{ENGLISH}

Gutzkow's opinion of the English language in view of the, political strivings of the Young Germans, seems more than incidental to our subject. " 'Die deutsche Sprache,' spann ich in einer Ecke des Salons das Gespräch weiter, 'ist leider für die Beredsamkeit wenig geeignet. Die englische ist so natürlich, wie nur je die Leidenschaft natürlich sein kann. Die französische Sprache ist die Sprache der Unterhaltung, der Verständigung, der einschmeichelnden Ueberredung. Die deutsche Sprache, so frei und schön sie den Dichtern zuströmt, ist für den gewöhnlichen Gebrauch zu abstrakt, sie sagt die Sachen nicht gerade heraus, sie umschreibt Vieles, sie ist viel su sehr Kurialsprache, um ganz die Sprache des Redners zu sein.' "'28

${ }^{27}$ VIII. Säkularbilder, 100-101. Die Zeitgenossen I, 142-148, 1837.

${ }^{28}$ VII. Briefe aus Paris, 196-197, 1842. 


\section{HEINE}

\section{BRITISH Politics}

Heine's attitude toward Britain does not allow of easy generalizations. Keenly appreciative of many of her political virtues, Heine was nevertheless not blind to her political faults. Isolated passages culled prejudicially from his works can be made to establish convincingly enough either Heine as the admirer of political Britain or Heine as the satirist of political Britain. But Heine was both, and it is only by constantly bearing that in mind that one can do justice to Heine and Britain.*

In a sense, too, for Heine Britain was the classic land of liberty,-but the glamor with which Börne had invested the term vanished before his keener sense of reality. In support of this there may be cited the familiar words on British, French and German liberty: "Was die Deutschen betrifft, so bedürfen sie weder der Freiheit noch der Gleichheit. Sie sind ein spekulatives Volk, Ideologen, Vor- und Nachdenker, Träumer, die nur in der Vergangenheit und in der Zukunft leben und keine Gegenwart haben. Engländer und Franzosen haben eine Gegenwart, bei ihnen hat jeder Tag seinen Kampf und Gegenkampf und seine Geschichte. Der Deutsche hat nichts, wofür er kämpfen sollte, und da er zu mutmassen begann, dass es doch Dinge geben könne, deren Besitz wünschenswert wäre, so haben wohlweise seine Philosophen ihn gelehrt, an der Existenz solcher Dinge zu zweifeln. Es lässt sich nicht leugnen, dass auch die Deutschen die Freiheit lieben. Aber anders wie andere Völker. Der Engländer liebt die Freiheit wie sein rechtmässiges Weib, er besitzt sie, und wenn er sie auch nicht mit absonderlicher Zärtlichkeit behandelt, so weiss er sie doch im Notfall wie ein Mann zu verteidigen, und wehe dem rotgeröckten Burschen, der sich in ihr heiliges Schlafgemach drängt-sei es als Gallant oder als Scherge. Der Franzose liebt

*The startling discrepancies and inconsistencies that seem everywhere present in Heine's pronouncements on politics are quoted by many critics of his time and of today as proof positive that Heine was a political opportunist at best and a political renegade at worst. His accusers usually cite his attitude toward Germany and France in support of these conclusions, and not infrequently their verdict of Heine, the politician, is colored by strong racial and political prejudices. Heine's opinions on Britain and things British afford material which is removed somewhat from the intensely personal and emotional elements that are usually present in the "Für oder gegen Heine" controversy, and hence provide a safer index of Heine's politics. 
die Freiheit wie seine erwählte Braut. Er glüht für sie, er flammt, er wirft sich $\mathrm{zu}$ ihren Füssen mit den überspanntesten Beteuerungen, er schlägt sich für sie auf Tod und Leben, er begeht für sie tausenderlei Torheiten. Der Deutsche liebt die Freiheit wie seine alte Grossmutter."1

Heine does not leave us in doubt as to the kind of liberty and its limitations that the Briton possesses: "Die Engländer sind ein häusliches Volk, sie leben ein begrenztes, umfriedetes Familienleben; im Kreise seiner Angehörigen sucht der Engländer jenes Seelenbehagen, das ihm schon durch seine angeborene gesellschaftliche Unbeholfenheit ausser dem Hause versagt ist. Der Engländer ist daher mit jener Freiheit zufrieden, die seine persönlichsten Rechte verbürgt und seinen Leib, sein Eigentum, seine Ehe, seinen Glauben und sogar seine Grillen unbedingt schützt. In seinem Hause ist niemand freier als ein Engländer, um mich eines berühmten Ausdrucks zu bedienen, er ist König und Bischof in seinen vier Pfählen, und nicht unrichtig ist sein gewöhnlicher Wahlspruch: 'My house is my castle.' ",2

After this analysis of British liberty Heine takes up French liberty and then finally sets one against the other. "Ist nun bei den Engländern das meiste Bedürfnis nach persönlicher Freiheit, so möchte wohl der Franzose im Notfall diese entbehren können, wenn man ihn nur jenen Teil der allgemeinen Freiheit, den wir Gleichheit nennen, vollauf geniessen lässt. . . . Weit geduldiger als der Franzose erträgt daher der Engländer den Anblick einer bevorrechteten Aristokratie; er tröstet sich, dass er selbst Rechte besitzt, die es jener unmöglich machen, ihn in seinen häuslichen Komforts und in seinen Lebensansprüchen zu stören." 3

These excerpts, - that seem convincingly to show that to Heine British liberty, although far from his realized ideal, typified in some respects the highest practical result of political strivings,are all found in the beginning of his "Englische Fragmente." In his last chapter of these "Fragmente" he briefly reviews the development of liberty in Western Europe and comes to the conclusion that British liberty is not very far evolved. "Keine

${ }^{1}$ Heinrich Heines Sämtliche Werke III. Reisebilder IV, Englische Fragmente, 435-436, 1828.

${ }^{2}$ III. Reisebilder IV, Englische Fragmente, 433-434, 1828.

${ }^{3}$ III. Reisebilder IV, Englische Fragmente, 434-435, 1828. 
gesellschaftliche Umwälzung hat in Grossbritannien stattgefunden, das Gerüste der bürgerlichen und politischen Institutionen blieb unzerstört, die Kastenherrschaft und das Zunftwesen hat sich dort bis auf den heutigen Tag erhalten, und obgleich getränkt von dem Lichte und der Wärme der neuern Zivilisation, verharrt England in einem mittelalterlichen Zustande oder vielmehr im Zustand eines fashionablen Mittelalters. Die Konzessionen, die dort den liberalen Ideen gemacht worden, sind dieser mittelalterlichen Starrheit nur mühsam abgekämpft worden; und nie aus einem Prinzip, sondern aus der faktischen Notwendigkeit sind alle modernen Verbesserungen hervorgegangen, und sie tragen alle den Fluch der Halbheit, die immer neue Drangsal und neuen Todeskampf und dessen Gefahren nötig macht. Die religiöse Reformåtion ist in England nur halb vollbracht, . . . Mit der politischen Reformation ist es nicht viel besser gegangen, die Volksvertretung ist so mangelhaft als möglich; wenn die Stände sich auch nicht mehr durch den Rock trennen, so trennen sie sich doch noch immer durch verschiedenen Gerichtsstand, Patronage, Hoffähigkeit, Prärogative, Gewohnheitsvorrechte und sonstige Fatalien; und wenn Eigentum und Person des Volks nicht mehr von aristokratischer Willkür, sondern vom Gesetze abhängen, so sind doch diese Gesetze nichts anderes als eine andere Art von Zähnen, womit die aristokratische Brut ihre Beute erhascht, und eine Art von Dolchen, womit sie das Volk meuchelt. Denn wahrlich, kein Tyrann vom Kontinente würde aus Willkürlust so viel Taxen erpressen, als das englische Volk von Gesetz wegen bezahlen muss, und kein Tyrann war jemals so grausam wie Englands Kriminalgesetze, die täglich morden, für den Betrag eines Schillings und mit Buchstabenkälte. Wird auch seit kurzem manche Verbesserung dieses trüben Zustandes in England vorbereitet, werden auch der weltlichen und geistlichen Habsucht hie und da Schranken gesetzt, wird auch jetzt die grosse Lüge einer Volksvertretung einigermassen begütigt, indem man hie und da einem grossen Fabrikorte die verwirkte Wahlstimme von einem rotten borough überträgt, wird gleichfalls hie und da die harsche Intoleranz gemildert, indem man auch einige andere Sekten bevorrechtetso ist dieses alles doch nur leidige Altflickerei, die nicht lange vorhält, und der dümmste Schneider in England kann voraussehen, dass über kurz oder lang das alte Staatskleid in trübseligen Fetzen 
auseinander reisst."4 These words are followed by a glorification of the French revolution.

Such damning judgments on Britain are difficult enough to reconcile with Heine's opening generalizations on Britain, the land of liberty. A consideration of additional excerpts from "Englische Fragmente" and from his other works only adds to the problem. The solution so glibly offered by some, namely a sudden or gradual absolute change of political faith seems insufficient as an explanation of most of these incongruities. For long before Heine had fallen from grace in the eyes of such radicals as Börne, he was guilty of them, and a study of his works, although it shows a development from radicalism towards conservatism that may be greater than that usually admitted as reasonable and natural, does not consistently allow of an assumption of political apostasy. It is hence in no attempt to mitigate the gravity of Heine's political crime-a great liberator "lobbying" as a pensioner of the French government,-that the argument is advanced, that for the explanation of Heine's treatment of political Britain the assumption of a dual Heine, a radical and an aristocrat, is both more plausible and more frequently adequate.

There is no necessity for calling Heine's love of liberty into question. Although probably as passionate as that of Börne, Börne's was republican in its nature, while Heine's was aristocratic and monarchic. Thus it happens that frequently British government with its retention of aristocracy made a stronger appeal to him than a French republicanism that would abrogate all distinctions and level everything down to mediocrity. "Den glänzenden Wahn von der Möglichkeit einer Republik in Frankreich," he says, "will ich hier nicht bekämpfen. Royalist aus angeborner Neigung, werde ich es in Frankreich auch aus Ueberzeugung." In a comparison of French and British liberty his reason demands that he espouse the cause of republicanism, but his heart soon extols the virtues of the British aristocracy. "Die Franzosen meinen, das englische Volk hege Freiheitswünsche gleich den ihrigen, es ringe, ebenso wie sie, gegen die Usurpationen einer Aristokratie, und daher gäben nicht bloss viele äussern, sondern auch viele innern Interessen die Bürgschaft einer

${ }^{4}$ III. Reisebilder IV, Englische Fragmente, 496-498, 1828.

${ }^{5}$ V. Französische Zustände, 37, 1832. 
engen Allianz. Aber sie wissen nicht, dass das englische Volk selbst durchaus aristokratisch ist, dass es nur in engsinniger Korporationsweise seine Freiheit oder vielmehr seine verbrieften vorrechtlichen Freiheiten verlangt, und dass die französische, allgemein menschentümliche Freiheit, deren die ganze Welt nach den Urkunden der Vernunft teilhaftig werden soll, ihrem tiefsten Wesen nach den Engländern verhasst ist. Sie kennen nur eine englische Freiheit, eine historisch-englische Freiheit, die entweder den königlichen grossbritannischen Untertanen patentiert wird oder auf ein altes Gesetz, etwa aus der Zeit der Königin Anna, basiert ist. Burke, der die Geister zu burken suchte und das Leben selbst an die Anatomie der Geschichte verhandelte, dieser machte der französischen Revolution zum hauptsächlichen Vorwurfe, dass sie sich nicht wie die englische aus alten Institutionen herausgebildet, und er kann nicht begreifen, dass ein Staat ohne Nobility bestehen könne. Englands Nobility ist aber auch etwas ganz anderes als die französische Noblesse, und sie verdient, dass ich ihr unterscheidendes Lob ausspreche. Der englische Adel stellte sich dem Absolutismus der Könige immer entgegen, in Gemeinschaft mit dem Volke, um dessen Rechte nebst den seinigen zu behaupten; der französische Adel hingegen ergab sich den Königen auf Gnade und Ungnade. . . . Anders erging es dem englischen Adel. Dieser hat seine Kraft erhalten, er wurzelt im Volke, dem gesunden Boden, der die jüngern Söhne der Nobility als edle Schösslinge aufnimmt und durch diese die eigentliche Gentry, mit dem Adel selbst, der Nobility, verbunden bleibt. Dabei ist der englische Adel voll Patriotismus, er hat bisher, mit unerlogenem Eifer das alte England wahrhaft repräsentiert, und jene Lords, die soviel kosten, haben auch, wenn es not tat, dem Vaterlande Opfer gebracht." —_And yet it needs to be remembered that Heine advocated the cause of the Whigs.

This innate predilection for aristocracy coupled with a veneration of power and strong personalities explains two strange phenomena in the radical but aristocratic Heine; his total misapprehension of Russian absolutism and his apotheosis of Napoleon. Both find their points of departure in his consideration of things British. When the Canning ministry was overthrown and the government fell into the hands of the Tories with Wellington,

- V. Französische Zustände, 58-60, 1832. 
always an abomination to Heine, at the helm, Heine saw the cause of liberty transferred from the keeping and guardianship of Britain to that of Russia. In his despair at the course of events he writes: "Vergleicht man in freiheitlicher Hinsicht England mit Russland, so bleibt auch dem Besorglichsten kein Zweifel übrig, welche Partei zu erfassen sei. Die Freiheit ist in England aus historischen Begebenheiten, in Russland aus Prinzipien hervorgegangen. . . J Jene Prinzipien aber, woraus die russische Freiheit entstanden ist oder vielmehr täglich sich weiter entfaltet, sind die liberalen Ideen unserer neuesten Zeit; die russische Regierung ist durchdrungen von diesen Ideen, ihr unumschränkter Absolutismus ist vielmehr Diktatur, um jene Ideen unmittelbar ins Leben treten zu lassen."7 This mistake in seeing in Russian autocracy and absolutism the guardian of the cause of liberty, colossal in its simplicity, as Brandes says, ${ }^{8}$ may be imputed rather to a lack of political acumen than to wilful political irresponsibility. For Heine had seen that the retention of the nobility in Britain had not precluded a large amount of political liberty and his aristocratic nature could ascribe progressivism even to a Russian aristocracy. An enlightened despotism, which he thought he then saw issuing into being in Russia was always less distasteful to him than that type of liberty represented by America, for example, with what he felt was a levelling of everyone and everything to mediocrity-"Amerikanische Lebensmonotonie, Farblosigkeit und Spiessbürgerei."

The other strange phenomenon at first glance, his worship of Napoleon, Heine shares with many radicals. It was in his moments of cold rationality merely the worship of a tremendous power, but at other times the vision of Napoleon as a liberator of his race must have cast a halo about the man of destiny and strangely warped his judgments whenever or wherever Napoleon is concerned. "Der Kaiser ist tot . . . Britannia! dir gehört das

${ }^{7}$ III. Reisebilder III, Italien, 279-280, 1828. Rambaud in his "Histoire de la Russie" speaks of Nicholas I, the Czar of this period as follows: En Europe comme en Russie, il fut le champion des idées conservatrices . . . Nicholas $I^{\text {er }}$. . e était une redoutable incarnation de l'autocratie. Son règne visait à être, suivant Lamartine "l'immobilité du monde" —on page 638, (1900).

${ }^{8}$ Main Currents in Nineteenth Century Literature VI, Young Germany, 113. Cf. Brandes for the preceding interpretation of Heine's politics.

${ }^{\ominus} \mathrm{V}$. Französische Zustände, 38, 1832. 
Meer. Doch das Meer hat nicht Wasser genug, um von dir abzuwaschen die Schande, die der grosse Tote dir sterbend vermacht hat. Nicht dein windiger Sir Hudson, nein, du selbst warst der sizilianische Häscher"-10 that is typical of his feeling toward Britain for the punishment of Napoleon.

\section{Wellington}

There can be no doubt that in Heine's judgment Wellington, in addition to his being a Tory, has committed the inexpiable crime of having been partly responsible for the overthrow of Napoleon. There is a personal animus in his criticisms of Wellington that lends support to such a contention. He writes of him: "Die letzten Begebenheiten haben bewiesen, dass ich in meinen früheren Schriften noch immer zu milde von ihm gesprochen. Man hat, verblendet durch seine täppischen Siege nie geglaubt, dass er eigentlich einfältig sei; aber auch das haben die jüngsten Ereignisse bewiesen. Er ist dumm wie alle Menschen, die kein Herz haben." '11 And-"Ich habe immer diesen Mann gehasst, aber ich dachte nie, dass er so verächtlich sei." 12 "In his criticism of the British soldier he has this to say of Wellington: "Wellington, dieser eckig geschnitzelte Hampelmann, der sich ganz nach dem Schnürchen bewegt, woran die Aristokratie zieht, dieser hölzerne Völkervampir, mit hölzernem Blick (wooden look, wie Byron sagt) und ich möchte hinzusetzen, mit hölzernem Herzen. Wahrlich, Altengland kann ihn zu jenen hölzernen Schutzmauern rechnen, womit es beständiz prahlt." ${ }_{13}$

His criticisms become more caustic, when he compares Napoleon and Wellington, and he looks upon Wellington's fame and fortune as a personal affront. "Der Mann hat das Unglück, überall Glück zu haben, wo die grössten Männer der Welt Unglïck hatten, und das empört uns und macht ihn verhasst. Wir sehen in ihm nur den Sieg der Dummheit über das Genie-Arthur Wellington triumphiert, wo Napoleon Bonaparte untergeht";,14 and "Was mich am meisten ärgert ist der Gedanke, dass Arthur Wellington ebenso unsterblich wird wie Napoleon Bonaparte. Ist doch in

${ }^{10} \mathrm{III}$. Reisebilder II, Ideen-Das Buch Le Grand, 160, 1826.

${ }^{11}$ V. Französische Zustände, 125, 1832.

${ }^{12} \mathrm{~V}$. Französische Zustände, 126, 1832.

${ }^{13}$ VII. Ueber körperliche Strafe in England, 260, 1828.

${ }^{14}$ III. Reisebilder IV, Englische Fragmente. Wellington, 490, 1828. 
ähnlicher Weise der Name Pontius Pilatus ebenso unvergesslich geblieben wie der Name Christi. Wellington und Napoleon! es ist ein wunderbares Phänomen, dass der menschliche Geist sich beide zu gleicher Zeit denken kann. Es gibt keine grössern Contraste, als diese beiden, schon in ihrer äusseren Frscheinung. Wellington, das dumme Gespenst, mit einer aschgrauen Seele in einem steifleinenen Körper, ein hölzernes Lächeln in dem frierenden Gesichte-daneben denke man sich das Bild Napoleons, jeder Zoll ein Gott!"'15

A letter that Heine wrote to Varnhagen from London on the receipt of Varnhagens "Blücher" is so thoroughly indicative of Heine's attitude to all of Napoleons conquerors and foes that it deserves to be cited in part: "Sonderbar! wie zwei Gleichgesinnte zur selben Zeit, jeder auf enthusiastische Weise, die feindlichsten Häuptlinge, Napoleon und Blücher, dem Publikum dargestellt. Und ich denke, wir haben beide doch dasselbe gewollt, und bleiben noch gleichgestimmt. Dennoch-ich will's gestehen-kann ich Ihren "Blücher" nicht mit. Liebe lesen; vielleicht ist noch in mir der Widerhall der Le Grandschen Märsche, ich ärgere mich, wenn ich bedenke, dass der Mann der Idee, der ideegewordene Mensch, nämlich Napoleon, durch jene zwei Menschen vernichtet worden ist, wovon der eine ein pharaospielender Husar und der andere ein von allem Enthusiasmus entblösster englischer Taugenichts war, oder besser gesagt, noch ist.-Sie können sich kaum vorstellen, wie jämmerlich er vorige Woche aussah, als ich ihn von St. James kommen sah; sein gnädiger König hatte ihm vielleicht eben mit Achselzucken den vollkommenen Sieg Cannings verkündigt, und er sah ihn auf den lachenden Gesichtern der vorbeigehenden Engländer. Die Idee siegte diesmal ohne Kanonen, und der Sieger von Waterloo musste abziehen. "16

\section{Cromwell}

Even Heine's valuation of Cromwell suffers because of his Napoleon cult. In a comparison of Cromwell and Napoleon, he tries, it seems, to mete out justice, but his concluding words show where his real sympathies are: "Napoleon blieb frei von der schlimmsten Blutschuld (die Hinrichtung des Herzogs von Enghien

${ }^{15}$ III. Reisebilder IV, Englische Fragmente. Wellington, 492, 1828.

${ }^{16}$ Heine Briefe (Hans Daffis) An Varnhagen von Ense, London, den 1. Mai 1827, I, 302-303, 112. Brief. 
war nur ein Meuchelmord); Cromwell aber sank nie so tief, dass er sich von einem Priester zum Kaiser salben liess und, ein abtrünniger Sohn der Revolution, die gekrönte Vetterschaft der Cäsaren erbuhlte. In dem Leben des einen ist ein Blutfleck, in dem Leben des anderen ist ein Oelfleck."17

\section{Canning}

Canning was for Heine the spokesman not only of British liberty, but of the cause of universal freedom. He compares him to Casimir Perier who had espoused that cause and then compromised it. "George Canning hingegen, weiland Gladiator im Dienste der Tories, als er endlich die Ketten der Geistessklaverei abschütteln konnte, erhob er sich in aller Majestät seines angebornen Bürgertums, und zum Entsetzen seiner ehemaligen Gönner, ein Spartakus von Downingstreet, proklamierte er die bürgerliche und kirchliche Freiheit für alle Völker und gewann für England alle liberalen Herzen und hierdurch die Obermacht in Europa. . .

Da sass ich nun ganze Tage auf der Gallerie der St. Stephanskapelle und lebte in seinem Anblicke und trank die Worte seines Mundes, und mein Herz war berauscht. . . . Diese Zeit wird mir ewig im Gedächtnis blühen, und nimmermehr vergesse ich die Stunde, als ich George Canning über die Rechte der Völker sprechen hörte, und jene Befreiungsworte vernahm, die wie heilige Donner über die ganze Erde rollten, und in der Hütte des Mexikaners wie des Hindu ein tröstendes Echo zurückliessen ..."18 "Und als er des Märtyrertodes starb, da legten wir Trauer an, und der achte August wurde ein heiliger Tag im Kalender der Freiheit." 19

\section{BRITISH LITERATURE}

General remarks on either the character of British literature or its position among the literatures of the world are rare in Heine's works. Heine accepts the superiority of the British drama and ascribes it with Börne to British political liberty. In his "Einleitung zum Don Quichotte" he says: "Den Spaniern gebührt der Ruhm, den besten Roman hervorgebracht zu haben, wie man den Engländern den Ruhm zusprechen muss, dass sie im Drama

${ }^{17}$ IV. Der Salon I, Französische Maler, 64-65, 1833.

${ }^{18}$ V. Französische Zustände, 68-71, 1832.

${ }^{19}$ III. Reisebilder III, Italien, 278, 1828. 
das Höchste geleistet." ${ }^{20}$ And in a review of Beers "Struensee": "Ob es überhaupt einer liberalen Regierung nicht unwürdig ist, den dramatischen Darstellungen beurkundeter Wahrheiten sich entgegenzusetzen, ist eine Frage, die wir seiner Zeit erörtern wollen. Unser Volksschauspiel, über dessen Verfall so trübselig geklagt wird, müsste ganz untergehen ohne jene Bühnenfreiheit, die noch älter ist als die Pressfreiheit, und die immer in vollem Masse vorhanden war, wo die dramatische Kunst geblüht hat, z. B. in Athen zur Zeit des Aristophanes, in England während der Regierung der Königin Elisabeth, die es erlaubt hatte, sogar die Greuelgeschichten ihrer eigenen Familie, selbst die Schrecknisse ihrer eigenen Eltern auf der Bühne darzustellen. Hier in Bayern, wo wir ein freies Volk und, was noch seltener ist, einen freien König finden, treffen wir auch eine ebenso grossartige Gesinnung und dürfen daher auch schöne Kunstfrüchte erwarten. "21

\section{Shakespeare and Byron}

The relations of Heine to Shakespeare ${ }^{22}$ and Byron $^{23}$ have been exhaustively treated, and they will be considered in the following pages only when Heine uses them to characterize other poets or the Briton.

\section{Scott}

Next to these poets Scott interests Heine most. This interest is not confined alone to Scott the novelist; Scott the historian proved even more fascinating.

Heine finds Scott's novels a healthy reaction against the "bürgerlicher Roman," and he proclaims Scott the founder of the historical novel. In his "Einleitung zum Don Quichotte" he says: "Ich glaube, in dieser Beziehung ist das Verdienst des zweiten grossen Dichters Englands noch nie anerkannt worden. Seine toryschen Neigungen, seine Vorliebe für die Vergangenheit waren heilsam für die Literatur, für jene Meisterwerke seines Genius, die überall sowohl Anklang als Nachahmung fanden und die aschgrauen Schemen des bürgerlichen Romans in die dunkleren Winkel der Leihbibliotheken verdrängten. Es ist ein Irrtum,

${ }^{20}$ VII. Einleitung zum "Don Quichotte," 316, 1837.

${ }^{21}$ VII. Beers "Struensee", 228, 1828.

${ }^{22}$ E. A. Schalles. Heines Verhältnis zu Shakespeare, 1904.

${ }^{23}$ J. Melchoir. Heines Verhältnis zu Byron, 1903. 
wenn man Walter Scott nicht als den wahren Begründer des sogenannten historischen Romans ansehen will und letztern von deutschen Anregungen herleitet. Man verkennt, dass das Charakteristische der historischen Romane eben in der Harmonie des aristokratischen und demokratischen Elements besteht; dass Walter Scott diese Harmonie, welche während der Alleinherrschaft des demokratischen Elements gestört war, durch die Wiedereinsetzung des aristokratischen Elements aufs schönste herstellte, statt dass unsere deutschen Romantiker das demokratische Element in ihren Romanen gänzlich verleugneten und wieder in das aberwitzige Geleise des Ritterromans, der vor Cervantes blühte, zurückkehrten." 24

Heine criticizes Scott's art in a comparison which he institutes between his novels and that of Cervantes. He finds that Scott's novels are not epic enough. The viewpoint is interesting, for it seems to suggest that the very qualities in British life which made for British superiority in the drama handicapped her novelists. Heine says: "Ich habe Walter Scott den zweiten grossen Dichter Englands und seine Romane Meisterwerke genannt. Aber nur seinem Genius wollte ich das höchste Lob erteilen. Seine Romane selbst kann ich dem grossen Roman des Cervantes keineswegs gleichstellen. Dieser übertrifft ihn an epischem Geist. Cervantes war, wie ich schon erwähnt habe, ein katholischer Dichter, und dieser Eigenschaft verdankt er vielleicht jene grosse epische Seelenruhe, die wie ein Krystallhimmel seine bunten Dichtungen überwölbt: nirgends eine Spalte des Zweifels. Dazu kommt noch die Ruhe des spanischen Nationalcharakters. Walter Scott aber gehört einer Kirche, welche selbst die göttlichen Dinge einer scharfen Diskussion unterwirft; als Advokat und Schotte ist er gewöhnt an Handlung und Diskussion, und wie in seinem Geiste und Leben, so ist auch in seinen Romanen das Dramatische vorherrschend. Seine Werke können daher nimmermehr als reine Muster jener Dichtungsart, die wir Roman nennen, betrachtet werden. $"{ }^{25}$

With all the acerbity that a Napoleon worshipper can muster, Heine inveighs against Walter Scott, the biographer of Napoleon. "Armer Walter Scott! wärest du reich gewesen, du hättest jenes

${ }^{24}$ VII. Einleitung zum "Don Quichotte, 314-315, 1837.

${ }^{25}$ VII. Einleitung zum "Don Quichotte" 315-316, 1837. 
Buch nicht geschrieben und wärest kein armer Walter Scott geworden! . . . Seltsam! der tote Kaiser ist im Grabe noch immer das Verderben der Briten und durch ihn hat jetzt Britanniens grösster Dichter seinen Lorbeer verloren! Er war Britanniens grösster Dichter, man mag sagen und einwenden, was man will. . . . Konnte aber der schottische Dichter nicht die Gestalt, so konnte er viel weniger den Charakter des Kaisers begreifen, und gern verzeih' ich ihm auch die Lästerung eines Gottes, den er nicht kennt. Ich muss ihm ebenfalls verzeihen, dass er seinen Wellington für einen Gott hält und bei der Apotheose desselben so sehr in Andacht gerät, dass er, der doch so stark in Viehbildern ist, nicht weiss, womit er ihn vergleichen soll. . . . Die Engländer haben den Kaiser bloss ermordet, aber Walter Scott hat ihn verkauft." ${ }^{26}$ Heine concludes this diatribe with an apotheosis of Napoleon: "Die böse Welt hat sich nun einmal vorgenommen, die Sache ganz anders zu betrachten wie der gute Walter Scott. Wenn dieser gute Mann, der sonst so bibelfest ist und gern das Evangelium zitiert, in jenem Aufruhr der Elemente, in jenem Orkane, der beim Tode Napoleons ausbrach, nichts anders sieht als ein Ereignis, dass auch beim Tode Cromwells stattfand: so hat doch die Welt darüber ihre eigenen Gedanken. Sie betrachtet den Tod Napoleons als die entsetzlichste Untat, losbrechendes Schmerzgefühl wird Anbetung, vergebens macht Walter Scott den Advocatum Diaboli, die Heiligsprechung des toten Kaisers strömt aus allen edeln Herzen, alle edeln Herzen des europäischen Vaterlandes verachten seine kleinen Henker und den grossen Barden, der sich zu ihrem Komplicen gesungen, die Musen werden bessere Sänger zur Feier ihres Lieblings begeistern, und wenn einst Menschen verstummen, so sprechen die Steine, und der Martyrfelsen St. Helena ragt schauerlich aus den Meereswellen und erzählt den Jahrtausenden seine ungeheure Geschichte." 26

How differently Byron would have treated Napoleon,"Byron, . . . der in seinem ganzen Streben den Gegensatz zu Scott bildete." in Napoleon the revolutionary principle and have portrayed him from that point of view. Heine's treatment of Byron is, of course, far more congenial, and his defense of Byron naturally

${ }^{26}$ III. Reisebilder IV, Englische Fragmente, The Life of Napoleon Buonaparte by Walter Scott, 448-454, 1828.

${ }^{27}$ III. Reisebilder II, Die Nordsee III, 116, 1826. 
becomes a bitter attack on Britain and the British. He quotes from Fürst Pückler-Muskau: "Lachen muss ich immer über die Engländer, die diesen ihren zweiten Dichter (denn nach Shakespeare gebührt Byron die Palme) so jämmerlich spiessbürgerlich beurteilen, weil er ihre Pedanterie bespottete, sich ihren Krähwinkelsitten nicht fügen, ihren kalten Glauben nicht teilen wollte, ihre Nüchternheit ihm ekelhaft war und er sich über ihren Hochmut, ihre Heuchelei beklagte. "'28

\section{The Briton}

This last quotation is as much a characterization of the Briton as it is of Byron and brings us to the question of Heine's opinion of the Briton. Judged by excerpts such as the one just quoted, which can be greatly multiplied, the verdict must be very unfavorable to the Briton. The question resolves itself into the same sort of problem as that of Heine's opinion of the German. The same invective and irony which Heine directs at Germany and German faults and foibles are here directed at Britain and British faults and foibles. But he who can find only such characterizations of the Briton would do Heine and the Briton the same injustice that those historians of literature have done to Heine and the German who forget the Kunz von der Rosen story and the numerous comparisons of the French and the Germans that are to the disparagement of the French.

In his essay on Shakespeare, ${ }^{29}$ he begrudges the Britons their greatest poet and he cannot forgive Shakespeare the misfortune of having been born in England. "Es wird mir flau zu Mute, wenn ich bedenke, dass er am Ende doch ein Engländer ist und dem widerwärtigsten Volke angehört, das Gott in seinem Zorn erschaffen hat. ... Welch ein widerwärtiges Volk, welch ein unerquickliches Land! Wie steifleinen, wie hausbacken, wie selbstsüchtig, wie eng, wie englisch. Ein Land, welches längst der Ozean verschluckt hätte, wenn er nicht befürchtete, dass es ihm Uebelkeiten im Magen verursachen möchte.... Ein Volk, ein graues, gähnendes Ungeheuer, dessen Atem nichts als

${ }^{28}$ III. Reisebilder IV, Italien III, Die Stadt Lucca-Preface-a quotation from "Briefe eines Vestorbenen. Ein fragmentarisches Tagebuch aus England," 378, 1830.

${ }^{29}$ V. Shakespeare, Mädchen und Frauen, 371-490, 1838. 
Stickluft und tödliche Langeweile, und das sich gewiss mit einem kolossalen Schiffstau am Ende selbst aufhängt. ... Und in einem solchen Lande und unter einem solchen Volke hat William Shakespeare im April 1564 das Licht der Welt erblickt." "30

And in the same vein: "Die gütige Natur enterbt nie gänzlich ihre Geschöpfe, und indem sie den Engländern alles, was schön und lieblich ist, versagte, und ihnen weder Stimme zum Gesang, noch Sinne zum Genuss verliehen und sie vielleicht nur mit ledernen Porterschläuchen statt mit menschlichen Seelen begabt hat, erteilte sie ihnen zum Ersatz ein gross Stück bürgerlicher Freiheit, das Talent, sich häuslich bequem einzurichten, und den William Shakespeare." 31

He begrudges Britain her other poets also; they are for him isolated martyrs to their national conditions. He says: "Es ist gewiss eine schreckliche Ungerechtigkeit, über ein ganzes Volk das Verdammungsurteil auszusprechen. Doch in betreff der Engländer könnte mich der augenblickliche Unmut zu dergleichen verleiten, und beim Anblick der Masse vergesse ich leicht die vielen wackern und edlen Männer, die sich durch Geist und Freiheitsliebe ausgezeichnet. Aber diese, namentlich die britischen Dichter, stachen immer desto greller ab von dem übrigen Volk, sie waren isolierte Märtyrer ihrer nationalen Verhältnisse, und dann gehören grosse Genies nicht ihrem partikulären Geburtslande, kaum gehören sie dieser Erde, der Schädelstätte ihres Leidens. Die Masse, die Stockengländer-Gott verzeih' mir die Sünde!-sind mir in tiefster Seele zuwider, und manchmal betrachte ich sie garnicht als meine Mitmenschen, sondern ich halte sie für leidige Automaten, für Maschinen, deren inwendige Triebfeder der Egoismus. Es will mich dann bedünken, als hörte ich das schnurrende Räderwerk, womit sie denken, fühlen, rechnen, verdauen und beten,-ihr Beten, ihr mechanisches, anglikanisches Kirchengehen mit dem vergoldeten Gebetbuch unterm Arm, ihre blöde, langweilige Sonntagsfeier, ihr linkisches Frömmeln ist mir am widerwärtigsten; ich bin fest überzeugt, ein fluchender Franzose ist ein angenehmeres Schauspiel für die Gottheit als ein betender Engländer!"’32

${ }^{30}$ V. Shakespeare, Mädchen und Frauen, 371, 1838.

${ }^{31}$ V. Shakespeare, Mädchen und Frauen, 375, 1838.

${ }^{32}$ VI. Vermischte Schriften III, Lutezia II, Teil, 327, 1842. 
As the foregoing passages have shown, Heine's analysis of the Briton does not always proceed in orderly, cumulative sequence, at least not at any great length. When he has indicated his emotional reaction by "Sie sind mir in tiefster Seele zuwider," or "Ich kann sie nicht leiden," he is likely to enumerate as many derogatory attributes as he can possibly compress into a sentence or two. Thus after a rather detached evaluation of liberty in Britain, he suddenly discusses the character of the Britons in their nonpolitical life: "Es sind wunderliche Käuze, diese Engländer. Ich kann sie nicht leiden. Sie sind erstens langweilig, und dann sind sie ungesellig, eigensüchtig, sie quäken wie die Frösche, sie sind geborne Feinde aller guten Musik, sie gehen in die Kirche mit vergoldeten Gebetbüchern, und sie verachten uns Deutsche, weil wir Sauerkraut essen."

The comparison of the Briton to a machine or an automaton is a favorite one with Heine. "Nimmermehr nach diesem schnöden Lande, wo die Maschinen sich wie Menschen, und die Menschen wie Maschinen geberden." 34 And "Das Bestimmte, das Genaue, das Ausgemessene und die Pünktlichkeit im Leben der Engländer beängstigte mich nicht minder; denn gleichwie die Maschinen in England uns wie Menschen vorkommen, so erscheinen uns dort die Menschen wie Maschinen." ${ }^{35}$

Heine is among the Young Germans who charge the Briton with hypocrisy. He finds British Sabbatarianism and church going incompatible with British materialism: "John Bull ist ein geborener Materialist, und sein christlicher Spiritualismus ist meistens eine traditionelle Heuchelei, oder doch nur materielle Borniertheit." And in a denunciation of American slavery he says: "Dabei machen diese Amerikaner grosses Wesen von ihrem Christentum und sind die eifrigsten Kirchengänger. Solche Heuchelei haben sie von den Engländern gelernt, die ihnen übrigens ihre schlechtesten Eigenschaften zurückliessen."

${ }^{33}$ V. Französische Zustände, Artikel VIII, 128, 1832.

${ }^{34}$ VII. Börne, Zweites Buch, 43, 1840.

${ }^{35}$ IV. Der Salon III, Florentinische Nächte II, 353, 1837.

${ }^{36}$ IV. Der Salon II, Zur Geschichte der Religion und Philosophie in Deutschland II, 211, 1835.

${ }^{37}$ VII. Börne, Zweites Buch, 45, 1840. 


\section{British Characteristics aNd Britain AND Germany}

British cant and hypocrisy without the saving grace of "Borniertheit," Heine finds in British politics: "Wir müssen es uns endlich gestehen, dass die offene Feindschaft der absoluten Könige uns minder gefährlich ist als des konstitutionellen John Bulls zweideutige Freundschaft. Die völkermeuchelnden Umtriebe der englischen Aristokratie treten bedrohlich genug ans offizielle Tageslicht, und der Nebel von London verhüllt nur noch spärlich die feinen Schlingen und Knoten, die das konferenzliche Protokollgespinst mit den parlamentarischen Fangfäden verknüpft." "38

This hypocrisy and egotism make him fearful of the welfare of his Fatherland: "Ich gestehe es, ich bin nicht ganz unparteiisch, wenn ich von Engländern rede, und mein Missurteil, meine Abneigung, wurzelt vielleicht in den Besorgnissen ob der eignen Wohlfahrt, ob der glücklichen Friedensruhe des deutschen Vaterlandes. Seitdem ich nämlich tief begriffen habe, welcher schnöde Egoismus auch in ihrer Politik waltet, erfüllen mich diese Engländer mit einer grenzenlosen, grauenhaften Furcht. Ich hege den besten Respekt vor ihrer materiellen Obmacht; sie haben sehr viel von jener brutalen Energie, womit die Römer die Welt unterdrückt, aber sie vereinigen mit der römischen Wolfsgier auch die Schlangenlist Karthagos." 39

And in the same vein: "Jedesmal wenn ich mit Engländern über meine Heimat rede, bemerke ich mit tiefster Beschämung, dass der Hass, den sie gegen Frankreich hegen, für dieses Volk weit ehrenvoller ist als die impertinente Liebe, die sie uns Deutschen angedeihen lassen, und die wir immer irgend einer Lakune unsrer weltlichen Macht oder unsrer Intelligenz verdanken; sie lieben uns wegen unsrer maritimen Unmacht, wobei keine Handelskonkurrenz zu besorgen steht, sie lieben uns wegen unsrer politischen Naivetät, die sie im Fall eines Krieges mit Frankreich auszubeuten hoffen." ${ }^{40}$

Heine satirizes Britain's foreign policy in the picturesque words: "Ich denke mir das egoistische England nicht als einen fetten, wohlhabenden Bierwanst, wie man ihn auf Karikatuern

${ }^{38}$ V. Französische Zustände, Artikel IV, 56-57, 1832.

${ }^{39}$ VI. Vermischte Schriften III, Lutezia, Zweiter Teil, 328, 1842.

${ }^{40}$ VI. Vermischte Schriften III, Lutezia, Zweiter Teil, Anhang, 441, 1846. 
sieht, sondern, nach der Beschreibung eines Satirikers, in der Gestalt eines langen, magern, knöchernen Hagestolzes, der sich einen abgerissenen Knopf an die Hosen wieder annäht und zwar mit einem Zwirnfaden, an dessen Ende als Knäul die Weltkugel hängt-er schneidet aber ruhig den Faden ab, wo er ihn nicht mehr braucht, und lässt ruhig die ganze Welt in den Abgrund fallen." 41

Heine does not seem tremendously impressed by Britain's power and he proclaims her decadent. "Durch diesen allzulangen Friedenszustand, durch zu grossen Reichtum und zu grosses Elend, durch die politische Verderbnis, die eine Folge der Repräsentativverfassung, durch das entnervende Fabrikwesen, durch den ausgebildeten Handelsgeist, durch die religiöse Heuchelei, durch den Pietismus, dieses schlimmste Opium, sind die Engländer als Nation so unkriegerisch geworden wie die Chinesen, und ehe sie diese letztern überwinden, sind vielleicht die Franzosen imstande, wenn ihnen eine Landung gelänge, mit weniger als hunderttausend Mann ganz England zu erobern." 42

This rather formidable array of adverse criticisms is, I think, fairly representative both in kind and tone. Heine, to be sure, felt that in their tone and possibly even in their kind, though that is less likely, some of them did not reflect his maturer judgments, for he confesses frankly on one occasion that he himself was partly responsible for his failure to enjoy or appreciate Britain: "Ich will es Ihnen gestehen, Maria, wenn mir in England nichts munden wollte, weder Menschen noch Küche, so lag auch wohl zum Teil der Grund in mir selber. Ich hatte einen guten Vorrat von Misslaune mit hinübergebracht aus der Heimat, und ich suchte Erheiterung bei einem Volke, das selber nur im Strudel der politischen und merkantilischen Tätigkeit seine Langeweile zu töten weiss." $" 43$

But although appalled by this political activity, Heine knew how to value it and in characteristically Young German manner he points to the vigorous political life of Britain and draws the moral from it for Germany: "In der Tat, eine gewisse poesielose Härte, Habsucht, Blutgier, Unermüdlichkeit, Charakterfestigkeit,

${ }^{41}$ V. Französische Zustände, Artikel IV, 58, 1832.

${ }^{42}$ VI. Vermischte Schriften II, Lutezia, Erster Teil, 207, 1840.

${ }^{43}$ IV. Der Salon III, Florentinische Nächte II, 353, 1837. 
ist den heutigen Engländern ebenso eigen wie den alten Römern, nur dass diese weit mehr Landratten als Wasserratten waren; in der Unliebenswürdigkeit, worin sie beide den höchsten Gipfel erreicht haben, sind sie sich gleich. Die auffallendste Wahlverwandtschaft bemerkt man bei dem Adel beider Völker. Der englische, wie der ehemalige römische Edelmann ist patriotisch; die Vaterlandsliebe hält ihn trotz aller politischen Rechtsverschiedenheit mit den Plebejern aufs innigste verbunden, und dieses sympathetische Band bewirkt, dass die englischen Aristokraten und Demokraten, wie einst die römischen, ein ganzes, ein einiges Volk bilden." ${ }^{44}$ In a more significant passage he covets this political activity, and the practical sense of the Briton (united with his power of opposition and his intense love of liberty) for the Germans, "who never act, but merely think": "Ueberhaupt haben die Engländer, wo es Handeln gilt, den Vorteil, dass sie, als freie Menschen, immer befugt sich frei auszusprechen, über jede Frage ein Urteil in Bereitschaft haben. Sie urteilen gleichsam mehr, als sie denken. Wir Deutsche hingegen, wir denken immer, vor lauter Denken kommen wir zu keinem Urteil; auch ist es nicht immer ratsam, sich auszusprechen; den einen hält die Furcht vor dem Missfallen des Herrn Polizeidirektors, den andern die Bescheidenheit oder gar die Blödigkeit davon zurück, ein Urteil zu fällen; viele deutsche Denker sind ins Grab gestiegen, ohne über irgend eine grosse Frage ein eigenes Urteil ausgesprochen zu haben. Die Engländer sind hingegen bestimmt, praktisch, alles Geistige verfestet sich bei ihnen, so dass ihre Gedanken, ihr Leben und sie selbst eine einzige Tatsache werden, deren Rechte unabweisbar. Ja, sie sind "brutal wie eine Tatsache," und widerstehen materiell. Ein Deutscher mit seinen Gedanken, seinen Ideen, die weich wie das Gehirn, woraus sie hervorgegangen, ist gleichsam selbst nur eine Idee, und wenn diese der Regierung missfällt, so schickt man sie auf die Festung. So sassen sechzig Ideen in Köpenick eingesperrt, und niemand vermisste sie: die Bierbrauer brauten ihr Bier nach wie vor, die Almanachpressen druckten ihre Kunstnovellen nach wie vor. $\mathrm{Zu}$ jener tatsächlichen Widerstandsnatur der Engländer, jenem unbeugsamen Eigensinn bei abgeurteilten Fragen kommt noch die gesetzliche Sicherheit, womit sie handeln können. Wir vermögen uns keinen Begriff

${ }^{44}$ V. Shakespeare, Mädchen und Frauen, 397-398, 1838. 
zu machen, wie weit die englische Opposition, die Gegnerin der Regierung innerhalb und ausserhalb des Parlaments, auf legalem Wege vorwärts schreiten darf. Die Tage von Wilkes begreift man erst, wenn man England selbst gesehen hat. Die Reisenden, die uns die englische Freiheit schildern wollen, geben uns in dieser Absicht eine Aufzählung von Gesetzen. Aber die Gesetze sind nicht die Freiheit selbst, sondern nur die Grenzen derselben. Man hat auf dem Kontinente keinen Begriff davon, wieviel intensive Freiheit zuweilen in jenen Grenzen zusammengedrängt ist, und man hat noch viel weniger einen Begriff von der Faulheit und Schläfrigkeit der Grenzwächter. Nur wo sie Schutz geben sollen gegen Willkür der Gewalthaber, sind jene Grenzen fest und wachsam gehütet. Wenn sie überschritten werden von den Gewalthabern, dann steht ganz England auf wie ein einziger Mann, und die Willkür wird zurückgetrieben. Ja, diese Leute warten nicht einmal, bis die Freiheit verletzt worden, sondern wo sie nur im geringsten bedroht ist, erheben sie sich gewaltig mit Worten und Flinten. Die Franzosen des Julius sind nicht früher aufgestanden, als bis die ersten Keulenschläge der Willkür, die Ordonnanzen, ihnen aufs Haupt niederfielen. Die Engländer dieses Maimonds haben nicht den ersten Schlag abgewartet; es war ihnen schon genug, dass dem berühmten Scharfrichter, der schon in anderen Ländern die Freiheit hingerichtet, das Schwert in Händen gegeben worden." $" 45$

\section{CONCLUSION}

The picture that Heine has drawn for us is a composite one. At times it is self-contradictory; it is frequently biased, as he himself confesses, but it never fails to be interesting. "Schickt einen Philosophen nach London, beileibe keinen Poeten" serve as a preface for some of his vituperative remarks on Britain and things British, but for others Heine, the Geschichtsphilosoph, need not apologize. His caustic criticisms of inconsistencies in the British body politic frequently do an injustice to historical Britain,

Where Freedom broadens slowly down

From precedent to precedent,

but his unerring vision in picking out these inconsistencies, joined

${ }^{45}$ V. Französische Zustände Artikel VIII, 127-128, 1832.

${ }^{46}$ III. Reisebilder IV, Englische Fragmente, 438, 1828. 
with his ability to mete out justice to conservatives and radicals alike, bear testimony to a deeper understanding, and a broader sympathy-at least for the nation and its institutions, if not for the people-than is revealed in the opinions of most of the Young Germans on Britain and things British. 


\section{LAUBE}

\section{British Politics}

In his "Erinnerungen" Laube comments interestingly on his search for political inspiration: "Ich persönlich war auch wunderlich genug: die Freiheitsfrage hatte mich nach Paris getrieben, und schon in der ersten Woche meines Aufenthaltes trat mir diese Frage schon in den Hintergrund. Oder vielmehr es trat mir in den Vordergrund, zu erfahren: wie ist dies Frankreich zu der Rolle gekommen, uns in Europa die Freiheitsmusik vorzuspielen, während doch England in der Staatsfreiheit zu viel sicherem Resultate gelangt ist? Der Hinweis auf England kam damals selten vor, und der kam nur vor bei stockernsthaften Leuten, welche kein aufmerksames, verbreitetes Gehör fanden. Wie ist diese so populäre französische Musik entstanden? Mit einem Worte; ich empfand allem Uebrigen voraus das Bedürfnis, die französische Geschichte mehr kennen zu lernen, wo man sie am leichtesten finden könnte, in Frankreich selbst."

Going to France for political inspiration was apparently the order of the day and of course it is not surprising that Laube should follow the crowd in that respect. But when Laube confesses that Britain typified liberty for him, and when he ascribes to a Briton his inspiration for his enthusiastic support of the Polish cause, it seems strange that a political pilgrimage to Britain was not his first objective. He says: "Als der polnische Krieg auf der Höhe stand und das Zünglein der Wage mitten inne hielt, brachte der alte englische Reformheld Lord Brougham-denn da drüben auf der sogenannten Freiheitsinsel wurde die grosse Reformschlacht geschlagen-ein historisches Essay über die polnische Frage. Er rief auf geschichtlicher Grundlage Europa auf für die Polen. Ich verschlang die Schrift, ich studierte, was er nur angedeutet, ich meinte, selbst schreiben zu müssen - die Schriftstellerei wollte mich wieder beim Schopfe fassen."

${ }^{1}$ Heinrich Laube-Gesammelte Schriften Erinnerwungen I, 380-381, (written 1868-1870). Refers to the year 1839.

${ }^{2}$ I. Erinnerungen, 130 (written 1868-1870). Refers to the years 18301831. 


\section{BRITAIN AND THE BRITONS}

A detailed analysis of Britain and the Britons can be found in Laube's "Die Bürger" (in "Das junge Europa"). It has seemed best to quote extensively from it without attempting any classification of the material. The analysis is put into the mouth of Hippolyt, one of the chief characters in "Das junge Europa." Hippolyt is a political and moral libertine, who, after a life of anarchical unrestraint in Germany, France and England, finally finds his death in America, in an attempt to save a negro from being lynched. In evaluating his opinions on European civilization, it is well to bear in mind the following excerpt from one of his letters to Valerius, the hero of Part Two, "Die Krieger": "Du sagtest einmal zu mir, ich müsse gar nicht über Nationen und deren Freiheit reden, denn ich hasste im Grunde jedes Gesetz weil es geniere, $\bullet$ ich wollte Zügellosigkeit - meinethalben!'»

Hippolyt's comments are obviously too intemperate to be set down as reflecting fairly the author's own views, and yet, I think, they can be taken, with a reasonable allowance for hyperbole, as an index of Laube's opinions. "Ich habe Paris verlassen," Hippolyt writes from London, "weil es mich langweilte, fürs gewöhnliche Leben ist fast Alles erlaubt, es reizt kein Widerstand, und doch lockt auch keine ungewöhnliche Kraft, wo sie sich aber erhebt, wird sie Fratze . . . . Es ist hier alles Caprice, eigentlich auch die Politik, das Volk ist viel zu gesellig, und zu gefallsüchtig, um eine dauernde Tüchtigkeit in sich und in einer Form zu erzeugen ... Bei aller Wichtigkeit, die ich Frankreich für die Weltgeschichte zuerkennen muss, bei der gebieterischen Wichtigkeit, dass es der Mittelpunkt europäischer Bewegung ist, kann ich doch von dem Gedanken nicht los, dies Volk sei eigentlich der Schalksnarr unserer Weltregierung, des Herrgotts Komödienhaus . . .

Und nun bin ich hier, und wie befinde ich mich? Sage mir um Gottes willen, was habe ich für eine Idee von Freiheit? Die britische soll die freieste Nation der Erde sein, und ich werde des Teufels bei dieser Nation. Ist das alles, dass ich nicht verhaftet werden kann, dass ich drucken lassen kann, was ich will und dergleichen? Ist das die Freiheit? Kann man in Sachen der Religion und Moral bornierter sein, als man hier ist? . . . Ein Sonntag hier

${ }^{3}$ VII. Das junge Europa, 2. Band, Die Bürger, 259, 1833-1837. 
in England hat das Ansehen, als ob Bann und Interdict auf der Erde lastete, furchtsame Stille schleicht über Strasse und Feld und Wald . . . Und diese Nation, welche solchergestalt das innerste Leben in eine traurige, dunkle Höhle vergräbt, ist die freieste? Wahrlich mein Bauer ... er lebt in goldener Freiheit neben diesem gottfurchtsamen, gottdürftigen Briten. Und diese Traueratmosphäre eines bornierten Gedankens, welchem sich aller innere Mensch dahier gebeugt hat, sie durchdrängt alle höhere Tätigkeit dieses Volkes. Die Literatur wird nach dem Moralkodex konstruiert und gerichtet, eine freie Schönheit, eine Schönheit an sich, besteht gar nicht; diese alten Grossmütter mit Hornbrillen, diese Reriews kritisieren in einer Altklugheit, dass jedem Künstler die Haare zu Berg stehen müssen; der eigentliche Brite, der nicht inkonsequent den Kreis seines Landes verlässt, darf kein Gemälde, keine Statue mit Wohlgefallen anschauen ... und so hält sich das freieste Volk mit geläufiger Formel in ärgster Sklaverei des bornierten Gedankens. Sie haben Shakespeare ignoriert, bis sie Garrick mit eminentem Talente dazu verführt hat, und wäre das rein Englische nicht so allgewaltig im grossen William ausgeprägt, wir würden wunderliche Dinge hören; jedenfalls ist dieser englische Dichter in Deutschland bergehoch grösser und richtiger gewürdigt als in England.Sie haben Shelley ausgestossen und in den Tod gejagt, sie haben Byron zu Tode gemartert, das ist das freie England . . .

Und nun diese Lüge bei aller Prüderie und Moral! Diese Eroberungen Englands in anderen Weltteilen, diese unmoralischen Ansprüche mit Blut, mit Strömen Blutes verfochtenen Ansprüche auf Amerika, diese ganze auswärtige Politik des allertrivialsten, kaufmännischen Vorteils mit lächelnder Hintansetzung alles Prinzips, verwünscht seist $\mathrm{du}$, heuchlerisches, puritanisches Albion, meiner Seele ein Greuel!"'4

The other side of the picture follows almost directly upon this: "Meine Unzufriedenheit mit England schliesst jedoch meine bereitwilligste Anerkenntnis der einzelnen Engländer nicht aus. Ich finde die Personen von einer ausserordentlichen Tüchtigkeit und Potenz, ich habe nie solche feste, in Mut, Charakter und Kühnheit gehärtete Menschen gesehen, oder richtiger-bei genauer Betrachtung erkannt als hier. Diese dichten, gefesteten, stäh-

‘VII. Das junge Europa, 2. Band, Die Bürger, 253-259, 1833-1837. 
lernen Innerlichkeiten, Herr des Himmels, welch ein Reich der Titanengewalt hätten sie aus diesen Inseln gemacht, wäre die Nation nicht eine kaufmännische geworden-der Kaufmann ist und bleibt ein geborener Feind des Poetischen, des Genialen ...

Wenn der Engländer heraustritt aus seinem Bannkreise der engen Sitte, des engen Glaubens, so ist er auch der grossartigsten Frechheit fähig... So haben die Engländer die Republik erfunden . . . so haben die Engländer das Meer bezwungen . . . Sie haben Shakespeare gezeugt, der als ordinärer Schauspieler die Poesie des Universums an seine Brust riss, sie haben Gibbon gezeugt, der das Christentum verfluchte, haben Chesterfield gezeugt, der die Tugend mit der Klugheit zerdrückte, Shelley, der Gott leugnete mit einem sanften Herzen, Byron, der die Gesellschaft schlug mit Fäusten, welche mit Ambra dufteten. Noch heute findet man eine Riesenpotenz im einzelnen Engländer."5

\section{BRITISH LITERATURE}

Laube finds difficulty in explaining Britain's pre-eminent position in literature. With Heine he finds British materialism and sense for the practical incompatible with Britain's thriving literature. But he does not proceed with Heine to call her poets isolated martyrs to their national conditions, geniuses who belong to no particular country. Laube is too "Young German" in his criticisms to be satisfied with such a solution. He had studied the state of literature in his own country and had come to certain definite conclusions on the relation of political and social conditions to art. "Es kann nur dem Unverstande einfallen," he says, "dass es uns an Dichtern fehle; wir sind reicher daran als je. An den Zuständen unserer Gesellschaft, an dem historischen Momente liegt es, dass wir keine Dramatiker haben." And "Er schmäht seine Zeit. Der ist aber kein grosser Dichter, welcher aus seiner Zeit nichts Schönes zu machen versteht. Er hat keine Kraft zusammenzudichten, unser neuer, grosser Poet ist der, welcher mit glücklichem Auge all die Verbindungslinien entdeckt, wo die wirbelnden Teile unserer jetzigen Tage zusammengehen."7 Laube's general comments on English literature are quite in the spirit of these aesthetic pronouncements. "Es ist wunderbar,

${ }^{5}$ VI. \& VII. Das junge Europa, 2. Band, Die Bürger, 260-261, 1833-1837.

'Moderne Charakteristiken I, 301, 1835.

${ }^{7}$ Moderne Charakteristiken II, 101-102, 1835. Refers to Tieck. 
dass ein so prosaisches Volk, wie das 'englische, Hauptmuster europäischer Literatur in Erfindung poetischer Formen und interessanter Begebenheiten geworden ist. Man sollte glauben, dergleichen Dinge müssten den Britten am ersten läppisch erscheinen, und unter so streng reeller Umgebung müssten sie durch und durch bar aller Phantasie und Illusion werden. Dass Shakespeare in Stratford aufwachsen, in London unser grösster Dichter werden konnte, schoben wir gern auf die Zeit der Elisabeth, wo dieser Staat erst anfing, alle Kräfte nach dem Handel hinzustrecken. Man kann ferner nicht begreifen, wie eine Gelehrsamkeit gleich der englischen, die in so enormem Ansehen steht, und das klassische und unklassische Altertum mit pedantischem, geschmacklosem Heisshunger durch einander geniesst, wie solche Gelehrsamkeit dem Schriftsteller so viel modernen Reiz übrig lasse."8 And "Vielleicht ist gerade eine solche Komposition, wie die des englischen Volkes, nötig zum chemisch literarischen Prozesse, das Rittertum des Barons, der Stolz, die Selbständigkeit des Bürgers, der praktische, untäuschbare Sinn des Kaufmanns, die beschränkten Formen in Sitte und Religion, die Jungfräulichkeit, die Prüderie der Frauen, die weite, bequeme Form des gemeinen Rechtes sind just die Kontraste, welche, der Dichtung zu statten kommen."

\section{SHAKESPEARE}

Quotations from Shakespeare are very frequent in Laube's works of the Young German period and not seldom are they in the original. They show an intensive knowledge of Shakespeare and leave us in no doubt as to the position Shakespeare held in Laube's affections. But a discussion of Laube's relation to Shakespeare would necessarily centre about Laube's activity as the director of the "Wiener Burgtheater" and cannot properly come within the limits set by this investigation. ${ }^{10}$

\section{ScotT}

Nothing is more interesting in the literary criticisms of "Das junge Deutschland" than its attitude toward British Romanticism.

${ }^{8}$ Moderne Charakteristiken II, 361, 1835.

${ }^{\circ}$ Moderne Charakteristiken II, 362, 1835.

${ }^{10} \mathrm{Cf}$. (a) Laube und Shakespeare-von Alexander von Weilern. ShakespeareJahrbuch 43. (b) Theaterkritiken $u$. dramaturgische Aufsätze by same author in Schriften d. Gesellschaft für Theatergesch. $7 \& 8$. 
The traditional characterization of the Young German movement as a reaction against Romanticism needs to be strongly modified. Most of the Young Germans embraced the romanticism of Byron and Shelley and Scott with ardor. It was against the excrescences of the romantic movement in Germany that they reacted and inveighed. Laube puts the case of the Young Germans pointedly in a discussion of Tieck: "Und so ist unser Zustand: Es fehlt uns von jeher an einem kernigen Mittelpunkte unseres Volkswesens, in welchem sich unsere zahlreichen Kräfte vereinigen könnten, und deshalb bleiben wir immer dieselben reichen Bettler Europas, die einander selbst die Lumpen vom Körper reissen. Da erfand man uns die Romantik-vielleicht war sie ein Anfang, uns innerlich historisch zu entwickeln, und herabgehend bis zu uns mit der Zeit einmal einen ganzen Deutschen zu Stande zubringen. Aber da bemächtigten sich ihrer die Narren, die Betbrüder und die Müssiggänger - die poetische Geschichte eines Volkes ist das hauptsächlichste, religiöse Element eines Volkes, es heisst eines Volkes Seele töten, wenn man dies verletzt-und Ludwig Tieck hat mit seiner Tändelei das Ehrwürdige jener altén Stoffe aufgelöst." 11 And "So muss heutiges Tags Ludwig Tieck angesehen werden: als ein geistreicher Privatmann in unserer Literatur, der an der Regierung keinen Teil haben kann, wegen Mangel an Grundsätzen und nationaler Würde ... D Der ganze, althistorische Camoens wird zu einer kleinen interessanten Novellenfigur zusammengedrückt, die an einer alten Liebschaft krankt. Wie wenig aber dieses Zusammendrücken nötig ist, möge man aus Walter Scott's besten Sachen ersehen." 12 In other words Scott's advantage lay in the fact that he was a Briton, for whom there was no "Mangel an einem kernigen Mittelpunkte des Volkswesens." He could portray life on a large canvas because his political and social background made him think in large, vigorous terms. Laube provides further illustrations of his point in a comparison of Spindler and Scott. "Dass aber dem Spindler noch immer jene Goldstücke fehlen, an die man denken muss, wenn man sich eines Scottschen Romans erinnert, daran ist nicht er schuld, sondern der Umstand, dass er ein Deutscher ist."13 And "Und jene

${ }^{11}$ Moderne Charakteristiken, II, 155, 1835.

${ }^{12}$ Moderne Charakteristiken II, 161-162, 1835.

${ }^{13}$ Moderne Charakteristiken II, 384-385, 1835. 
Szenen" (in Ivanhoe, Kenilworth and the Talisman) "fehlen Spindler. Er ist auch in seinen Romanen nie dreister als ein Deutscher, und das ist zu wenig, denn der Deutsche ist auch schüchtern, wenn er dreist ist." ${ }^{14}$

Laube bears a splendid tribute to Scott's power as a novelist in the words: "Es kümmerte die Demokratie nicht, dass Scott die Baronenherrschaft verherrlichte, und die Aristokraten gewahrten es im Taumel kaum; das Wirkliche, Wahrhaftige seiner Poesie liess die künstlichen Definitionen, die Begriffsfeindschaften nicht aufkommen . . . So ereignete sich von England aus das Unglaubliche, dass ein einzelner Mann länger als ein Dezennium die ganze Leserwelt Europas beschäftigte und bei uns allein beschäftigte. Es existiert seit Lope de Vega und Shakespeare kein Beispiel in der Geschichte, dass ein Schriftsteller bei solch immenser Produktion auch immer neu erfinden konnte."15

With Heine, Laube feels that Scott's "Life of Napoleon" was a blot on his fame. "Erst mit dem 'Leben Napoleons,' zerstörte er die Illusion, und raubte einem grossen Teile seiner Leser jene Unbefangenheit, welche der Empfängnis eines Romans so überaus günstig ist."

\section{BYRON}

Laube finds Byron the exemplar of the new spirit in poetry, but he does not attempt an analysis of his works. His appreciation of Byron runs to a vindication of Byron's life and to an attack on British philistinism. In this respect he strongly resembles Heine, but it must be confessed that his epithets, though strong and trenchant enough, lack something of the picturesqueness of Heine's vocabulary. "Es ist eine Naturerscheinung, dass die Hauptbeweger der Menschheit seit mehreren Jahrhunderten immer auf jener stockphiliströsen Insel sich erheben, wo die Religion stets eine platte, lederne Beschränktheit und die Poesie eine gespreizte Schulfuchserei war. Aus England ist Shakespeare und die Freiheit und Lord Byron gekommen. Lord Byron ist aber der wilde Vater jener modernen Poesie ohne Pietät, welche mit nackten Händen ans Herz greift. Er gibt den Ton zu jener politischen Politik an, aus welcher wir noch keinen Ausgang gefun-

${ }^{14}$ Moderne Charakteristiken II, 386, 1835. Cf. also Laube on Spindler in Laube Geschichte der deutschen Literatur o. J.

${ }^{15}$ Moderne Charakteristiken II, 359, 1835. 
den haben, welcher sich die kaufmännische Prosa und die leeren, formellen Konstituierer bemächtigt haben, und für welche wir in die Gefängnisse geworfen werdfen." 16 And "Jenes Farewell, das er dort auf dem Verdeck sang, das ist deine unauslöschliche Anklage, du aberwitziges, prosaisch moralisches England mit deinen Pfaffen und alten Weibern gotteslästerlicher Frömmigkeit." And finally: "Hier in Venedig war's, in diesem Palaste, wo einst Thomas Moore mit ihm speiste, und wo er beim Dessert hereintrat und ihm seine Memoiren übergab. Dieser mittelmässige Poet, dessen glatter Wortschatz die Mittelmässigkeit besticht, hat es gewagt, den Auftrag jenes Sterbenden zu veruntreuen, er hat die Memoiren verfälscht herausgegeben. Dies prüde Krämervolk hat die beiden ersten Poeten unserer Tage, den Napoleon und Lord Byron zu Tode gemartert, und hinterher durch seine Poeten, die Edlen Scott und Moore verleumden lassen. Pfui über sie! Wenn das Volk nicht sonst so gross, so konsistent tüchtig wäre, ich k.önnte es hassen wegen dieser historischen Geschwüre." ${ }^{18}$

\section{The BRITON}

Laube's opinion of the Briton is plainly seen from the quotations already given. Three additional excerpts may serve to complete his delineation. "Jene rötlich schimmernden Konturen des Engländers, jener hochblonde Schein des Haares, des Sommersprossenteints, der Nasenspitze, der lichten Augenwimper und Brauen, jene Ungeschicktheit der Bewegungen, jene langen Bewegungen mit Arm und Bein, jenes erfrorene Schweigen des Antlitzes, jene Geduld und kaltblütige Ruhe, das alles ist ein so persönlicher Gegensatz des Franzosen, dass es ihm ohne irgend einen Gedanken an Politik das Herz in Grimm bewegt."19 "Und diese Franzosen, denen die Zeit so wenig, sie hoffen jemals den zeitkargen präzisen Engländer einzuholen? Diesen ewiggehassten stummen Rivalen?"20 "Dies sind untrügliche Zeichen einer starken Nation: sein Land, seine Fahne verlassen wird gebrandmarkt, die Umstände seien noch so schwer zu richten, die Veranlassung sei noch so wirksam. Diese Beschränkung muss eine

\footnotetext{
${ }^{16}$ VIII. Reisenovellen I, Lord Byron, 357-358, 1834-1837.

${ }^{17}$ VIII. Reisenovellen I, Lord Byron, 301, 1834-1837.

${ }^{18}$ VIII. Reisenovellen I, Lord Byron, 366, 1834-1837.

${ }^{19}$ IV. Französische Lustschlösser, 194-195, 1840.

${ }^{20}$ IV. Französische Lustschlösser, 188, 1840.
} 
Nation festhalten, darin muss sie borniert sein, wenn sie politisch stark werden will. Wo hat man von einem Engländer gehört, dass er gegen England gefehlt! Sei er auch ein einsamer Mann tausend Meilen von der Heimat gewesen." 21

${ }^{21}$ Französische Lustschlösser, 49, 1840. 


\section{WIENBARG}

\section{British Politics}

No one could be more insistent in his demands for a vigorous national and political life as a background for literature than Wienbarg, the father of Young German Aesthetics. In his criticism of the culture of his day in Germany, he points out the absence of such necessary postulates of the life of the spirit as "National gefühl, gemeinsame Zwecke, gemeinsames Leben, öffentliches Leben." Thus we find him saying: "Es fehlt uns an einem gemeinsamen Mittel der Bildung, weil es uns an gemeinsamem Leben fehlt," "es mangelt uns an grossen gemeinsamen Zwecken, es mangelt uns an öffentlichem Leben," "_ "Nationalgefühl muss dem Gefühl fürs Schöne, politische Bildung der ästhetischen vorausgehen." 3 With such an enunciation of the presuppositions of the cultural life, it would almost seem that some elaborations of his theme would take the shape of illustrative comment on conditions elsewhere. But allusions to France or Britain are almost entirely lacking, and ancient Greece is only mentioned in passing.

\section{BRITISH LITERATURE}

The key to Wienbarg's estimate of British literature is to be found chiefly in his "Aesthetische Feldzüge." A consideration of the drama, the lyric and the novel from his Young German standpoint includes a discussion of the three typical (at least from the standpoint of Young Germany) exemplars of these genres, Shakespeare, Byron and Scott.

\section{SHAKESPEARE}

Wienbarg pleads for a drama whose content shall be national and shall reflect the spirit of the times. "Greift in die Zeit, haltet euch an das Leben," 4 is his theme, and its many variations stand out on almost every page of his "Aesthetische Feldzüge." It was Diderot and Rousseau and Shakespeare who renewed the contact of litera-

${ }^{1}$ Aesthetische Feldzüge, 83, 1834.

${ }^{2}$ Aesthetische Feldzüge, 65-66, 1834.

${ }^{3}$ Aesthetische Feldzüge, 9, 1834.

${ }^{4}$ Wanderungen durch der Tierkreis, 256, 1835. 
ture with life and thus wrenched the arts from the "Unnatur" of the eighteenth century;- "Diderot und Rousseau hiessen die beiden unsterblichen Männer, die sich aus der Unnatur ihres Jahrhunderts zuerst herausrissen. Rousseaus Emil legte den Grund zu einer neuen Erziehung der europäischen Jugend, sein contrat social den Grund zur französischen Revolution, dem Todesstoss der europäischen Tyrannis in Kunst, Sitte und Staat. Für die Deutschen ging zu gleicher Zeit Shakespeare auf und damit ein flutendes Luftmeer von Genien und Kräften, woran die unersättliche Phantasie ewigen Stoff zur Schwelgerei findet. Lange Zeit nahm man den Genuss nur so hin, ohne über die Quelle desselben nachzudenken; so wie man sich die französische Revolution mit der Phantasie aneignete, ohne etwas Arges dabei zu denken und ohne aus der Schläfrigkeit des bürgerlichen Lebens zu erwachen. Dann aber kam eine Zeit und sie dauert fort, wo man sich fragt, woher stammt diese Fülle von Leben und Kraft, die uns an Shakespeare entzückt und seine dichterischen Gebilde so lebensderb, so kühn, so unübertrefflich macht? Und da lautete die Antwort: das hat er sich nicht auf seinem Stübchen zusammengedichtet, das hat er nicht aus dem Stegreif phantasiert, das hat er gelernt und herausgeschaut aus dem wildbewegten, grossartigen Leben, das seine Jugendträume umflatterte und ihn später als Jüngling und Mann in seine Mitte aufnahm."

\section{BYRON}

With the exception of Heine, the Young Germans had little to do with lyric poetry, either creatively or by way of criticism. Prose as the more natural medium for the expression of their age was more studiously cultivated. In his "Aesthetische Feldzüge" Wienbarg says, for example: "Meine Bemerkungen werden sich anreihen an die Werke einiger neueren Schriftsteller, an Byron und Goethe in poetischer, an Heinrich Heine in prosaisch stilistischer Beziehung. Die Prosa wird vor allen Dingen unser Augenmerk sein .. . Die Prosa ist eine Waffe jetzt, und man muss sie schärfen . . ."6 Wienbarg, however, joins the other Young Germans in unstinted praise of Byron. The reason, of course, for the tremendous popularity of Byron among the Young Germans is to be accounted for by the political charac-

' Aesthetische Feldzüge, 82-83, 1834.

'Aesthetische Feldzüge, 139, 1834. 
ter of his poetry, its embodiment of the spirit of the age which they themselves had so inadequately expressed in the prose of their letters, polemical pamphlets, lectures and novels. Wienbarg finds that Byron has given the best expression to the revolutionary spirit of his times. "Ich verstehe unter dem Ausdruck: die moderne Lyrik ist revolutionär das: jeder grosse Dichter, der in unserer Zeit auftritt, wird und muss den Kampf und die Zerrüttung aussprechen, worin seine eigene Brust sich findet. Der Dichter müsste blind sein, oder kalt oder gefühllos, oder heuchlerisch, oder kein grosser Dichter, der mit seiner Leier über den ungeheuren Riss hinweghüpft, welcher die Gegenwart von der Vergangenheit trennt. Er müsste nicht der Dolmetscher der Natur und Menschheit sein, wenn er nicht das Ringen und den Schmerz dieser Menschheit verstände, fühlte und in den Wogen der Poesie dahinbrausen liesse. Byron war ein grosser Dichter, und daher war seine Lyrik, die er nur leicht in ein episches Kleid einhüllte, durch und durch revolutionär, was um so grossartiger und erschüttender bei ihm hervortritt, als er im Schoss des Glücks geboren, Lord und künftiger Pair des Reichs, früh bewundert und beneidet war."7 And "Die Lyrik der neuen Zeit ist das poetische Ausströmen des Revolutionären; revolutionär war die Lyrik Goethes, als er jung und feurig war, revolutionär war die Lyrik des grossen Britten, der in Goethes, des Jünglings, Fusstapfen trat und jene Leier mit neuen Saiten bezog, welche Goethe beiseite gelegt hatte." And finally- "Hass gegen Aristokratie, Tyrannei, Kastengeist, Unnatur der Sitte, Pfaffentum, dagegen Liebe zur Freiheit, ungebundenes Streben, griechisch-heitere Ansicht des Lebens und der Liebe, verbunden mit den Gefühlen der Ehre und Sittlichkeit, selbst mit dem Bewusstsein alten Adels und vormaligen, feudalen Geschlechtsglanzes bildeten die Grundelemente seiner Poesie, worin Goethe mit tiefem Blick ein Kind des Griechentums und des Mittelalters gesehen hat. Byron war der einzige revolutionäre Dichter, den Goethe anerkannte ..."9

\section{ScotT}

Wienbarg's criticisms of Scott are in accord with his Young German demands. His break with romanticism was absolute,-

${ }^{7}$ Aesthetische Feldzüge, 277-278, 1834.

${ }^{8}$ Aesthetische Feldzüge, 275, 1834.

${ }^{\ominus}$ Aesthetische Feldzüge, 278-279, 1834. 
medieval romancings and the historical drama in general are not for him; he demands "zeitgeschichtliche Sittenromane." "Muss die neue, schönere Zeit, die heranzieht, die als Samenkorn in tausend und abertausend deutschen Herzen verschlossen liegt, um an irgend einem Frühlingsmorgen neuerwacht ins Leben zu blühen, muss sie haben Barone, Ritter, Knechte, Dome, Pfaffen, galanten Frauendienst, Minnegesang und alle jenen Denk- und Lebensformeln, wodurch sich das Mittelalter auszeichnete? Und da glauben wir, mit Nein antworten zu müssen, und ich denke, alles was jung ist in Deutschland, steht auf unserer Seite und lebt der frohen Hoffnung, dass auch ohne Verjüngung mittelaltriger Formen eine Wiedergebärung der Nation, eine poetische Umgestaltung des Lebens, eine Ergiessung des Heiligen Geistes, eine freie, natürliche, zwanglose Entfaltung alles Göttlichen und Menschlichen in uns möglich sei . . ."1n "Ich verhehle es nicht, ich fühle selbst den lebhaften Sporn-nicht ins alte, romantische Land zu reiten-nein, einen zeitgeschichtlichen Sittenroman zu entwerfen, dessen Idee ich schon eine geraume Weile mit mir herumtrage." Such sentiments applied to an analysis of Scott lead to the following criticisms: "Veit Weber wurde der Vorgänger Walter Scotts. Eine deutsche Erfindung erhielt wie gewöhnlich, jenseits des Kanals, ihre Ausführung im Grossen. Betrachtet man die deutschen Anfänge dieser Romanschule und ihren Zusammenhang mit dem Götz, so muss man eine lobenswerte und poetische Bewegung der damaligen Zeit darin anerkennen, eine Reaktion gegen die gelehrte Trockenheit der Geschichte und eine Ahnung, ein Bedürfnis lebendiger Gegenwart. Allein sie hätte die Revolution nicht überleben sollen, sie hätte der wirklich anbrechenden Zeitgeschichte ihre Talente abliefern sollen. Als Walter Scott sich an ihre Spitze stellte und seine Feudalromane schrieb, reagierte sie gegen das Leben der Gegenwart und trug, glaubt mir, das Ihrige dazu bei, das so hoffnungreich bewegte Europa mit ihren alten Historien und Wiegenliedern einzuschläfern und um das Gefühl und die Tat der Gegenwart zu betrügen. Sie verdarb die Geschichte und die Gegenwart zugleich. Sie weckten scheinbar die Toten und machte die Lebendigen scheintot-träumerisch." 12 He damns

${ }^{10}$ Aesthetische Feldzüge, 29-30, 1834.

${ }^{11}$ Wanderungen durch den Tierkreis, 257, 1835. A reference to Weber's

"Die Vehme" with its relation to Scott's "House of Aspen."

${ }^{12}$ Wanderungen durch den Tierkreis, 251, 1835. 
with faint praise, only to condemn finally and utterly the hybrid genre - as unhistorical, without content and unpoetical. "Ich verkenne nicht das grosse Verdienst der neueren historischen Romanschule, deren Stifter er war. Ich setze es hauptsächlich darin, dass sie den Leserkreis unendlich erweitert und gleichsam zur Literaturfähigkeit des ganzen Publikums den ersten Grund gelegt hat. Allein sie hat überall nur eine äusserliche Bewegung, flüchtige und bald vergessene Eindrücke hervorgebracht. Sie hob nicht, wärmte nicht, begeisterte nicht.

Wie konnte sie das? Sie zeigte keinen Gehalt. Den der Zeit versagte sie sich selber, den der Poesie verweigerte ihr die Muse. "'13

\section{The Briton}

Allusions to the Briton are very infrequent. In his criticisms of the German, Wienbarg seldom institutes comparisons; he is content to point out the flaws of his countrymen without adding to the offense thus given by citing the superior virtues of foreigners. He harps insistently on the German's inability to act, his proneness for abstract thinking, his lack of savoir faire; and he pleads for the transfusion of the intensity and thoroughness of his intellectual life into his political life. Thus for example: "So gründlich, wie wir studieren, so gründlich sollen wir leben. Deutschland war bisher nur die Universität von Europa, das Volk ein antiquarisches, ausgestrichen aus der Liste der Iebendigen und geschichtlich Fortstrebenden." 14 And "Dieses Unvermögen zu handeln, weder auf die hergebrachte Weise, die im Mittelalter grossartig, kühn, dann bürgerlich, städtisch, ehrenfest, ins Philisterhafte ausartete, noch auf fremden Antrieb nach auswärtigen Gesetzen, macht aus dem gegenwärtigen Deutschland eines der verworrensten, peinlichsten, schläfrigtrübseligsten Länder der Welt." 15 These quotations will supply the background for his discussion of "Bildung," in which he makes one of his few allusions to the Briton. "Bildung, meine Herren, ist ein weites Wort, und lässt sich viel darein fassen. Von theologischer, philosophischer, juristischer Bildung macht man sich leichter Begriffe, aber wo von höherer, allgemeiner, von humaner Bildung die Rede ist, da schwebt der Begriff ins Unbestimmte und weder der Bildung Ziel noch Umfang tritt

${ }^{13}$ Wanderungen durch den Tierkreis, 248, 1835.

${ }^{14}$ A esthetische Feldzüge, 74-75, 1834.

${ }^{15}$ Wanderungen durch den Tierkreis, 118-119, 1835. 
den Meisten recht klar vor Augen. Das kommt, wir sind wie die Fische ausser dem Wasser, und leben in keinem rechten Element, wir geben uns im Ganzen Mühe genug, uns zu bilden und vielleicht mehr als irgend je eine Nation auf dem Erdboden; allein, obgleich wir schon behaupten können, dass wir unendlich mehr wissen und lernen, als z. B. unsere Nachbarn überm Rhein und selbst die Engländer, so möchten wir uns schwerlich mit Recht, wenn wir im Leben mit ihnen zusammenstossen, mehr Bildung beilegen dürfen, als ihnen. Gutmütig scheinen wir den Fremden, und das ist Alles, was sie Gutes von uns sagen. Hören wir dagegen unsere Philosophen, so liegt die Unvollkommenheit unserer Bildung darin, dass wir noch nicht tief genug in die Paragraphen ihrer Philosophie eingedrungen sind, und während der Franzose, der Engländer, die äussere Form und Fassung an uns vermisst, vermisst ein Hegel noch die erste, notwendige, philosophische Grundbildung bei den Gebildeten der Nation."16

Much more favorable to the German is Wienbarg's discussion of Heine, Byron and "der englische Anstand." "Das englische Verhältnis ist freilich bei weitem zwiespältiger und unsittlicher noch, als selbst das unsrige; aber der englische Anstand leimt die Aussenseiten so glatt und fest zusammen, dass dem Dichter nur der Schein, die Kunst und die Lüge, nicht die Wahrheit zur Schilderung offen steht. Will ein englischer Lord gemein und liederlich sein, so kann er's auf jedem Fleck in Alt-England, servatis servandis. Will aber ein Byron die glühenden Ströme seines Herzens ausgiessen, so muss er sich hüten, die englische Gesellschaft zu kompromittieren. Daher wählt er die epische Form und sperrt sich aufrichtig gegen die Identifikation mit seinen Helden. Die Heineschen Lieder sind deutsche für Deutsche und fielen gerade, wie es scheint, aus dem rechten Zentrum in den rechten Zeitpunkt. Wir verdienten sie nicht besser, und die Engländer sind ihrer nicht einmal wert." 17

Critical as Wienbarg is of the failings and weaknesses of the German, he has absolute confidence in the superiority of his genius over that of the Briton and he prophesies: "Wenn in Alt-Europa das zögernde Endstück von der Domuhr des Mittelalters abläuft, dann wollen wir sehen, ab der saxo-britische Genius befähigter, als

${ }_{16}$ Aesthetische Feldzüge, 63-64, 1834.

${ }^{17}$ Wanderungen durch den Tierkreis, 166-167, 1835. 
der franko-gallische, ein neues selbstständiges Leben der Freiheit $\mathrm{zu}$ beginnen, ob der englische Leopard ohne Vorsprung des ${ }^{18}$ deutschen Löwen in die Bahn des neuen Völkertages einbricht." ${ }^{18}$ Wanderungen durch den Tierkreis, 131, 1835. 


\section{MUNDT}

\section{British Politics}

No writer of Young Germany finds Britain and the Britons so congenial as Mundt. Heine's opinions run the gamut from the most intense admiration of British institutions and a few isolated Britons to the deepest abhorrence of everyone and everything British. Laube's attitude is Heine's in miniature minus the picturesqueness of Heine's invectives and diatribes. Though vigorous in his praise of British institutions and not caustic in his characterization of the Briton, Gutzkow can hardly be called an apologist for Britain, while Börne's favorable impressions would gain authority, if they were the expression of a more intimate knowledge of Britain and the Britons.-Mundt, however, is a frank admirer of Britain and the Britons. His unreserved sympathy for British life frequently forces him to be an apologist for the Briton, and he enjoys the rôle. In fact, he evinces, at times, a certain "von oben herab" attitude toward the criticisms that to him wrongly interpreted British character.

Everywhere Mundt tries to find the historical bases for the phenomena that he observes. He is aided in this attempt by his sympathetic approach to the phenomena in question. $\mathrm{He}$ is conscious of the racial tie that binds him to England, and that predisposes him to a kindly judgment. A sojourn in Paris in the Spring of 1837 aroused no enthusiasm in him for France and French institutions, and he was always mindful of the differences in race and temperament of the Teuton and the Gaul. He leaves Paris for London and his first letter from London finds him an admirer of his brother Teuton. "In Frankreich," he writes, "sah ich zu meinem Leidwesen, wie die Franzosen mit allen Vorteilen eines gänzlich verschiedenen Naturells, welche sie über die Deutschen voraus haben, doch so wenig bis jetzt erlangten, und wie sie nach so vielen gewonnenen und verlorenen Schlachten, nach so vielem Blut, Schweiss, Kampf und Arbeit, doch entfernter sind als jemals von der Erreichung eines glücklichen und vollkommenen Zustandes. In England aber stellt sich mir ein ganz anderes Schauspiel menschlicher Bestrebungen vor Augen, und ich sehe hier mit erschrok- 
kenem und herzklopfendem Staunen, zu welchen hohen Dingen das germanische Element, diese auch nur angestammte Natur, zu gelangen vermag. Es gibt wohl keinen Deutschen, der nicht in England die Volksverwandtschaft des Naturells froh empfände, aber es ist auch ein grosser Schmerz für ihn damit verbunden, ein Schmerz und ein Neid, die mich in Frankreich nie beschlichen haben. Dass die Franzosen mit ihren den Deutschen entgegengesetzten Eigenschaften Nichts erlangten, als höchstens eine Pressfreiheit, die auch schon wieder halbtot gehetzt und durch tausend Intriguen gelähmt ist, kann mich weltgeschichtlich bekümmern und traurig machen, aber meine deutsche Natur fühlte sich dabei wieder auf der anderen Seite gewissermassen aufgerichtet, denn ich dachte bei mir selbst: die deutsche Michelnatur ist also noch nicht die unglückseligste in diesem modernen Völkerleben, man muss vielmehr gläubig und redlich an ihr festhalten, und muss sehen, ob sie nicht noch anderer und bei weitem besserer Dinge fähig ist, diese so viel geschmähte Michelnatur! Und ich liess den gallischen Hahn krähen, so laut und prahlerisch er wollte, und wandte mich ab von ihm, nachdem ich noch einmal auf den Père Lachaise gegangen war, um von Börne's Grab eine gelbe Immortelle zu pflücken, von dem Grab unseres grössten Patrioten, der in der Ferne sein Vaterland am meisten geliebt und gescholten hat, der Sympathieen für sein krankes, deutsches Herz suchte, aber keinen Trost und kein Heil bei Frankreich fand. Und hier in Ihrem England treffe ich wieder mit meiner germanischen Natur zusammen, mit der die Engländer Alles erreicht haben, die Deutschen aber nichts." 1 That realization discourages him, but he finally rejoices that Germanic Britain has achieved such triumphs, for from her he can learn how liberty can be evolved from the Germanic nature. "Oder soll ich mich hier einfach freuen über den Triumph, den das germanische Element in England davongetragen, indem es hier durch seine gediegenen Resultate alle kühnere Beweglichkeit des französischen Naturells weit überflügelt hat? Ich bin noch immer nicht Kosmopolit genug zu dieser uneigennützigen Freude, und doch scheinen mir die Thränen kindisch, die ich weinen sollte über den Triumph des germanischen Elements ausserhalb Deutschlands. Ich begrüsse lieber die hohe Britannia als meine Lehrerin, an deren Mienen und

${ }^{1}$ Spaziergänge und Weltfahrten I. Briefe aus London I. Brief (written in (1837) published 1838, II. Tagebuch aus Paris, Pages 4-6. 
Worten ich fortan andächtig hängen will, und sie soll mir sagen, wie die Freiheit aus der germanischen Natur zu entwickeln ist, in der sie nach allen Richtungen des Lebens hier ursprünglich gegeben und von Anfang an verborgen liegt.",2

\section{BRITISH LIBERTY}

In his "Geschichte der Gesellschaft," he speaks of liberty as the birth-right of every Briton, while the German is still, according to him, in doubt as to the desirability of political liberty. "Auf dieser Insel der Freiheit, die in ihre eigentümlichen Nebellichter und traulichen Schatten eingesponnen liegt, hier scheint sich früher und mächtiger als anderswo die wahre Aufgabe der Geschichte ihrer Lösung zugeneigt zu haben, und zwar in der Freiheit des konstitutionellen Staatslebens, die hier zugleich mit dem religiösen, christlichen Geist in allen Lebensäusserungen sich so fest und unzertrennlich verbunden hat. Bei anderen Völkern hat es sich in der neueren Zeit immer nur um das Sein oder Nichtsein konstitutioneller Staatsformen in einem schwankenden Prozess gehandelt, und man hat sich auf dem Kontinent kaum noch zu einer höheren Ansicht davon erhoben, als dass man sich die Konstitution gewissermassen als Schutzpocken einimpfen zu müssen gemeint hat, um den Ansteckungsstoff der Despotie, welcher noch immer die Geschichte der Völker durchzieht, dadurch zu kreuzen. Dagegen ist der Engländer gewissermassen konstitutionell geboren, und während die Franzosen erst einer Revolution bedurften, um die Rechte des Menschen und des Bürgers zu erklären, während die Deutschen, verwickelt in die Massen ihrer Bücher, metaphysischen Systeme, berichtigten und unberichtigten Zeitungsartikel sich heute noch darüber streiten, was besser sei, die in der frischen Brust des Volkes selbst geborene Freiheit, oder die in göttliches Recht eingewickelte Knechtschaft, da haben die Engländer es schon als ihr Geburtsrecht (Birth-right) angenommen, frei zu sein und konstitutionell regiert zu werden; sie haben in das Grundgesetz ihres Staatslebens aufgenommen und zu einem staatsrechtlichen Prinzip erhoben, dass, was schon Sidney aufgestellt hat, 'die Freiheiten der Nation von Gott und der Natur kommen, nicht aber von den Königen!' In dem Statut Wilhelms aber,

${ }^{2}$ Spaziergänge und Weltfahrten, I. Brief 6, 1838. 
heisst es ausdrücklich,' 'die Gesetze Englands sind das Geburtsrecht seines Volkes!'

Ein glückliches Volk also von Anbeginn seines Daseins, das Volk der Engländer, dass es nicht nackt ausgesetzt erscheint auf dem Eiland des Staats, wie andere Völker, sondern dass es etwas mit auf die Welt gebracht hat, ein angestammtes Recht, das Recht frei zu sein." 3

Mundt ascribes Britain's political strength to the continuity of her historical development. A visit to Westminster Abbey leads him to make the following observations, which he incorporates in his seventh letter" and in his "Geschichte der Gesellschaft." "Die Westminster Abtei ist England selbst, seine Geschichte, seine Vergangenheit . . England hat nicht mit seiner Vergangenheit gebrochen, England ist fast das einzige Land in ganz Europa, in dem die Vergangenheit so dicht und nahe an der Gegenwart steht, ohne Hass, sondern durch Liebe und Stolz verbunden. Für den Engländer gibt es keinen ancien régime, keine alte und moderne Zeit, seine Annalen haben keine feindlichen Abschnitte und Spaltungen, die bis in die Gesinnung hinein nachwirken könnten. In der englischen Geschichte ist eine ununterbrochene Geradlinigkeit der Entwicklung, die zwar ihre Nüancen hat, wie in neuerer Zeit die Reformbill, aber im Ganzen wie ein fortlaufender Strom sich weiter bewegt, nur nach Massgabe von Ebbe und Flut bald anschwellend, bald nachlassend in seinen Wellen." 4

From this unbroken continuity of Britain's political development Mundt correctly derives some of the controlling principles of British political life. They may sound truistic to the student of British politics, but they are unique, at least in the emphasis Mundt places upon them, for Young German observers. For example, Mundt finds that Britain's political equilibrium is maintained by what he calls a patriarchal "Zug von Ehrfurcht," which in a time of stress abrogates all differences. "Die Ehrfurcht, die dem französischen Charakter fremd ist, ist in England ein eigentümlicher Einschlag, der das ganze Staatsgewebe verfestigt, und die Politiker, welche diesem glücklichen Eiland längst eine Revolution weissagten, haben nicht auf die Ehrfurcht gerechnet, die hier

${ }^{3}$ Geschichte der Gesellschaft, 402-403, 1844.

${ }^{4}$ Spaziergänge und Weltfahrten, 7. Brief. 126-127, 1838. 
ein ganz besonderer Begriff für das Staatsleben ist, der dem englischen Staatsleben etwas von dem Wesen des Familienlebens mitteilt, und aus Ehrfurcht vor der Vergangenheit, aus der Ehrfurcht vor der Freiheit, und aus der Ehrfurcht vor den Standesvorzügen sich mischt, drei Ehrfurchten, die mit denen, von welchen Goethe in den Wanderjahren spricht, sich vielleicht in Einklang setzen lassen."

From this he proceeds to analyze the two political parties and to predicate the distinguishing feature of British political development, viz: conservative progress. "Daher kommt es, dass der Gegensatz von Torysmus und Whigismus, der hier Alles zerteilt, auch wieder alles bindet, und dass diese beiden Hälften, in welche das englische Leben auseinander zu fallen scheint, zusammen ein vollständiges Ganze ausmachen. Ob dieses Ganze, diese Einheit ein Schein ist, oder eine dauernde Wahrheit, ich weiss es nicht, aber diese Einheit besteht, sie besteht in den Gegensätzen, und diese Gegensätze begründen ebensowohl den konservativen Charakter Englands, als sie die Reform bedingen und die freie Entwicklung der Institutionen. England ist die konservative Form des liberalen Fortschrittes, es ist in manchem Betracht das China der modernen Freiheit." The question "Was ist Tory," "Was ist Whig," Mundt answers as follows: "Eine geistreiche Spiegelfechterei der Geschichte, ein chemischer Prozess, der in das Entgegengesetzte seiner Bestandteile umschlägt. Man kann ein englischer Whig sein und doch glauben, dass die Tories ein wesentliches Element für die Verfassung bilden, dass sie nur nicht für das Regiment taugen und deshalb vom Ruder fern gehalten werden müssen." 7

Mundt's intimate knowledge of British life gave him a distinct advantage over other Young Germans. Mundt sought out the Briton in his home, and the riddles of British life, before which others stood helpless, resolved themselves readily for him. To his other criteria of British life, he can add "das Wechselverhältnis von Sitte und Gesetz" as an important factor in the valuation of British politics and institutions. "Wie viele Rätsel lösen sich, wenn man das Privatleben einer Nation mitangeschaut hat.

${ }^{5}$ Spaziergänge und Weltfahrten, 7. Brief, 124-125, 1838.

${ }^{6}$ Spaziergänge und Weltfahrten, 7. Brief. 125. 1838.

${ }^{7}$ Spaziergänge und Weltfahrten, 7. Brief. 136. 1838. 
Wissen Sie, welches in diesem Sinne das merkwürdigste Verhältnis ist, das ich hier beobachtet habe? Das Wechselverhältnis von Sitte und Gesetz in einem so elastischen und mit so grossartiger Freiheit sich ausdehnenden Staatsleben. Ich habe gesehen, dass diejenigen Staaten am festesten bestehen, wo die Freiheit und Ordnung nicht bloss durch das Gesetz getragen und sanktioniert, sondern auch durch die Sitte geboten werden. Die Sitte ist ebenso gewaltig in England, als das Gesetz, und es gibt Beziehungen, in denen sie noch mit stärkerer Kraft bindet und zur Pflichterfüllung ruft. Die Sitte ist hier mächtig, und hält den Geist des Gesetzes aufrecht, selbst wo man es nach dem Buchstaben übertreten könnte. Wo ist die Pressfreiheit, das Recht der unbeschränkten Assoziation und der öffentlichen Zusammenkünfte weniger gemissbraucht worden, als in England, und wo werden kolossalere Massen dadurch in Bewegung gesetzt, als hier. Wo man das Gesetz nicht gegen sich hat, tritt hier die Sitte auf, und zügelt so den ausschweifenden Versuch, der über die Schranken hinaustreiben könnte. Das englische Volk hat liberale Gesetze und legitime Sitten, Freiheit in seinem Staatskörper und Begrenzung in seinem Privatcharakter, es hat einen scharfen politischen Verstand und ein mildes Familiengemüt, und das sind die Angeln, in denen seine harmonische Existenz schwebt."8

\section{BRITISH LITERATURE}

The aesthetic slogans enunciated by Wienbarg are reiterated by Mundt in his "Aesthetik." The return of art to life, idealization of the immediate, reality and actuality, the search for beauty in life and action, the philosophy of action-these are some of the watchwords that Mundt incorporates in his exposition of the aesthetic principles of Young Germany. But his appeal is largely scientific and allusions to contemporary literature are lacking. The "Aesthetik" published in 1845 marks rather the aesthetic philosopher than the literary reformer,-an attempt to give to the world the system of aesthetics that grew from the practice and theories of Young Germany, and that after the movement had run its course was looking for the approval of the academic world of its cardinal working principles. Hence there are but few references to English literature in this work of Mundt. In passing he does not fail to take notice of the sense of the practical of the

${ }^{8}$ Spaziergänge und Weltfahrten, 7. Brief, 140-141, 1838. 
Briton, but he does not elaborate on the Briton's attitude toward life in its bearing upon literature. For references to English literature one must look to his earlier works, particularly to his "Geschichte der Literatur der Gegenwart."

Mundt's "Geschichte der Literatur der Gegenwart" comprises fifteen lectures, but one of which is devoted to English contemporary literature. (French literature is treated in two lectures). The lecture covers twenty-six pages and it is preceded by a table of contents-that reads as follows: "Die englische Literatur. Die Grundelemente des Nationallebens. Die englische Verfassung, die Reformbestrebungen, und der damit zusammenhängende Umschwung des geistigen und literarischen Lebens. Die Erneuerung der englischen Poesie gegen Ende des achtzehnten Jahrhunderts. Das romantische Element in England. Einfluss der ersten romantischen Dichtungen Walter Scott's. Robert Burns. William Cowper. William Wordsworth. Coleridge. Southey. Lord Byron. Shelley. Thomas Moore. Die englischen Romane. Walter Scott. Cooper. Washington Irving. Sealsfield. Bulwer. Morier. Boz." With such a formidable array of names, it has seemed best to confine Mundt's opinions to his general prefatory remarks and to his treatment of the poets to whom he has given most space.

Mundt finds that English literature is peculiarly nationalistic and bears the stamp of the political and social conditions from which it springs as does no other literature. It derives its life from the "Genius des englischen Volkes," its constitution; it does not exist independently of the political life. Hence the character of of the public life determines its character; it mirrors the weakness or strength of the political period of which it is a part. Literati and philosophers cannot shape definitely its course; "die aus der Entwickelung des Staatsorganismus herfliessenden Bedingungen des öffentlichen Lebens und der öffentlichen Meinung sind normgebender, als aller Einfluss der Denker." And "Es gibt nur eine Idee in England, welche eine allgemeine und unumstössliche Gültigkeit erlangt hat, und diese ist sogleich die höchste, praktische, nämlich die Idee der konstitutionellen Freiheit." 10 The revival of English literature at the end of the eighteenth century is particularly the result of the political reforms, the reform of parliament.

${ }^{9}$ Geschichte der Literatur der Gegenwart, 408-409, 1842.

${ }^{10}$ Geschichte der Literatur der Gegenwart, 408, 1842. 
With this preface Mundt approaches the analysis of British poets. He pays particular attention to the political character of English romanticism, exemplified as it is in the Lake School, especially in Coleridge and Southey.

\section{BYRON}

But the great creative genius of the period and its truest exponent is, to Mundt's mind, Lord Byron. He embodied, as did no other, the spirit of the English literature of his time, viz. "die Entfesselung des innersten Nationalgeistes von allen beengenden Formen."11 Mundt does not find Byron unenglish or cosmopoli$\tan$ as Heine does. Byron is for Mundt a composite of English characteristics-of its virtues and defects. "Man wird Lord Byron einen echt nationalen Dichter Englands nennen müssen, wenn man sein dunkelglühendes, wie durch Widerstand erst recht stürmisch gewordenes Gefühl, den scharfen Reiz der Kontraste in seinen Anschauungen, den Ekel am Leben bei aller Lust und Fähigkeit zum Genuss, den unaufhörlich bohrenden Skeptizismus, welcher sich mit der weichsten, lyrischen Hingebung verbindet, den auf Eigenheiten versessenen Trotz, der sich doch wieder allumfassend den Interessen der Völker und der Menschheit öffnet, die Liebe und die Begeisterung für die Freiheit bei despotischer Ichsucht und verhärteter Menschenverachtung, wenn man diese und andere, den Byron charakterisierenden Eigenschaften ermisst. In keinem andern Dichter haben sich vielleicht die Nationalfehler und Nationaltugenden so sehr zu einer Persönlichkeit geeinigt wie in Byron, der sie auf ihrer höchsten Spitze und darum auch in ihrem grellsten Widerspruche aufzeigt. In ihm hat der englische Nationalcharakter sich in allen seinen Spitzen zusammengefasst, und ist in ihm zugleich mit sich selbst verfallen, und hat sich die schmerzhaftesten Wunden beigebracht. So ist Lord Byron das eigenste und liebste Kind Englands, und doch zugleich der Ausgestossene, der Verworfene seiner Nation gewesen. Sie verachteten sich zuletzt gegenseitig, Lord Byron und England, aber sie gehören ewig zu einander, und in ihrem wunderbaren Verhältnis liegt ein Geheimnis verborgen, nämlich das Geheimnis eines Wendepunktes des englischen Volkscharakters, der sich seiner innern Gegensätze bewusst wird und sich dieselben

${ }^{11}$ Geschichte der Literatur der Gegenwart, 414, 1842. 
gegenständlich zu machen sucht."12 Mundt discusses two of Byron's works, Manfred and Don Juan,-- "doch erblicken wir ihn nur in seinem Don Juan in der Tat auf dem Gipfel seines Genius." His Manfred Mundt finds "nur ein schwacher Aufguss nach der grossen Goetheschen Dichtung." "Dagegen" he continues, "bewegte sich Byron in seinem Don Juan im höchsten und vollkommensten Rechte seiner Genialität, und bemeisterte sich darin des ihm eigenst zugehörenden Stoffes mit einer gigantischen Schöpfungskraft . . . Es herrscht eine gewisse Universalität in diesem Gedicht, die alle Tonarten des Lebens sich zu eigen macht, in allen Abgründen und auf allen Höhen heimisch ist. Byron hat den höchsten Aufschwung und die höchste Erschöpfung seines Geistes darin gemalt, er hat gezeigt, dass er alles Grosse und Erhabene der Welt erkannt, und sich mit dieser Erkenntnis in den Abgrund der Vernichtung gestürzt. Die Sprache, die sich in England kaum noch in dieser allumfassenden Beweglichkeit gezeigt hat, schmiegt sich allen diesen Extremen der Darstellung, auf das Wunderbarste an, und gibt das Komische wie das Tragische, den herben Spott, die jubelnde Lust, die neckische Tändelei, die unverschämte Zudringlichkeit der Zote, die in sich selbst verlorene metaphysische Schwermut, die geheimste Süssigkeit des Genusses, die Naivetät der Unschuld, die ausgesuchte Verderbtheit des Lasters, die Weisheit der Erfahrung mit gleicher Meisterlichkeit wieder. ${ }^{14}$ Mundt concludes his analysis of Byron with the words: "Die übrigen Schöpfungen des Lord Byron, wie alles sonst zur Charakteristik seines Lebens und seiner Poesie Gehörige, können wir hier um so eher übergehen, da sich das Urteil über keinen Dichter so sehr erschöpft und festgestellt hat, wie über diesen, mit welchem das Interesse ebenso sehr, wie die Koketterie der Lesewelt, bei allen Nationen sich zu schaffen gemacht." 15

\section{SHELley}

Next in interest for Mundt among contemporary writers in Britain is Shelley. He devotes three pages to a discussion of Shelley's life, his poetry and his relation to German poetry. "By-

\footnotetext{
${ }^{12}$ Geschichte der Literatur der Gegenwart, 415, 1842.

${ }^{13}$ Geschichte der Literatur der Gegenwart, 416, 1842.

${ }^{14}$ Geschichte der Literatur der Gegenwart, 416-417, 1842.

${ }^{15}$ Geschichte der Literatur der Gegenwart, 417-418, 1842.
} 
rons Freund, Percy Bysshe Shelley, kämpfte zum Teil denselben Kampf mit der Welt und der englischen Nationalität, doch ist er noch entschiedener als ein Märtyrer dieser Nationalität anzusehen. Seine Begabung war bestimmter als die des Lords auf eine philosophische Grundlage gestellt, doch liess ihn eben dies Bedürnnis der Spekulation, das ihn trieb, noch bitterer und unwiderbringlicher mit seinen heimatlichen Verhältnissen zerfallen." ${ }_{16}$ Then follows a brief review of Shelley's clash with Oxford and English orthodoxy. As a poet, Mundt finds Shelley "der stärksten und zartesten, süssesten und schrecklichsten Töne mächtig. Er versteht alle Geheimnisse des innigsten Naturlebens zu belauschen und ist eingeweiht in der Märchenwelt der Mondnächte, in dem verschwiegensten Liebesgekose des Frühlings. Seine Begeisterung richtete sich aber auch auf das Freiheitsringen der Völker, hier bald satirisch anstachelnd, bald elegisch verklingend, und die politischen Verhältnisse Englands selbst wurden ihm Gegenstand ernster und scharfer Gedichte . . . Aber aus dem gärenden Chaos aller dieser Ideen, wie sicher auch der Dichter sie hin und herzuwenden scheint, vermag sich doch das, was sich Shelley als sein höchstes Ziel setzt, nämlich die Reformierung der Weltzustände im Sinne der wahren individuellen Freiheit, in keiner bestimmten Gestalt abzuklären. Es bleibt nur der schmerzliche Missklang eines in seinen tiefsten Tiefen zerissenen Geistes zurück. ${ }^{17}$ Shelley's Cenci is treated in one sentence: "Unter Shelleys dramatischen Arbeiten ragt besonders sein Trauerspiel die Cenci hervor, in dem er sich mit einer gewissen Ueberlegenheit und Klarheit der Tragik dieses ungeheuren Stoffes bemächtigt hat."18 It is interesting to note that Mundt was able to appreciate the merits of Shelley's translations from Goethe's Faust. He says: "Wie Shelley die deutsche Poesie in sich aufzunehmen verstanden, zeigen seine Uebersetzungsproben von Goethe's Faust, die, wie kein anderer Uebersetzer vermocht hat, den Geist der deutschen Dichtung, wenn auch in freien Formen, doch in treuem Eindruck, wiedergegeben." ${ }^{18}$

\section{Scott, Dickens, Carlyle}

Mundt's estimate of Scott is best seen in his discussion of the British novel, in which he sums up his opinion of Scott's position

${ }^{16}$ Geschichte der Literatur der Gegenwart, 418, 1842.

${ }^{17}$ Geschichte der Literatur der Gegenwart, 419-420, 1842.

${ }^{12}$ Geschichte der Literatur der Gegenwart, 420, 1842. 
in literature. "Der Erhebung der englischen Poesie in diesem Zeitraum ist die Bedeutung nicht nachzustellen, welche gleichzeitig die englische Prosa, besonders im Roman, gewonnen. Von Walter Scott's wichtigem Einfluss auf diese Literaturperiode überhaupt haben wir schon zu Anfang gesprochen und ihm das Verdienst zuerkennen müssen, durch Anregung des romantischen Geistes in der Poesie den neuen Anstoss in die englische Nationalpoesie gebracht zu haben. Die Natur und das Volksleben der schottischen Hochlande, das er in seiner Lady of the Lake so meisterhaft geschildert, ward ihm auch in seinem Waverley, mit welchem er die Reihe jener europäisch berühmten Waverley Romane begann, zuerst zum Gegenstand des Romans. In diesen Romanen liess er sich auf einer breiteren Basis seiner literarischen Tätigkeit nieder, die sehr viel dazu beigetragen, die englische Literatur mit dem Interesse und der Liebe des übrigen Europas zu vermitteln und sie aus ihrer Abgeschlossenheit $\mathrm{zu}$ einer weltliterarischen Stellung zu erheben." 19 Mundt does not seem to be in agreement with the genre, the historical novel. He calls it a hybrid creation, ${ }^{20}$ in which neither history nor poetry can come into their own, "aber es hat doch auf den Geschmack und die 3ildung der Leserwelt nicht unvorteilhaft gewirkt, und eine zwar sehr materielle, aber doch gesunde und kräftige Speise abgegeben." ${ }^{20}$ A further analysis of this new genre provides him with a transition for a few words on Scott, the historian, with which he closes his treatment of Scott. "Walter Scott war aber auch als Historiker selbst nicht so glücklich, sich auf die reine Höhe eines wahrhaft geschichtlichen Standpunktes zu erheben, denn sein Leben Napoleons war es gerade, das in seinen literarischen Ruhm die erste Erschütterung brachte. ' 20

Mundt closes his chapter of contemporary English literature with a few words on Boz. They show us how closely he followed new developments in English literature, for but a few years had passed since Dickens with his nom de plume, Boz, had attained recognition in his own country. "Unter den in den letzten Jahren neu aufgetretenen Autoren ist es fast nur einem gelungen, sich eine allgemeine Geltung zu verschaffen und die fortgesetzte Aufmerksamkeit in Anspruch zu nehmen. Dies ist Boz, der in seinen

${ }^{10}$ Geschichte der Literatur der Gegenwart, 421-422, 1842.

${ }^{20}$ Geschichte der Literatur der Gegenwart, 422-423, 1842. 
Kleinmalereien nationaler Lebenszustände ein ausserordentlich liebenswürdiges Talent an den Tag gelegt hat. Man könnte ihn einen mikroskopischen Dichter nennen, so sehr gehen seine, echt nationalen, Genrebilder oft ins Kleinliche. Aber in dieser liebevollen Hingebung an das Unscheinbarste und in diesem Aufsuchen der verborgensten Einzelheiten des menschlichen Lebens zeigt Boz auch wieder seine poetische Natur, die aus Allem Nahrung zu schöpfen versteht, und in jedem abgelegenen Winkelchen der Wirklichkeit den göttlichen Funken und den ewigen Gedanken herauserkennt." 21

Mundt then institutes a comparison between $\mathrm{Boz}$ and Jean Paul, which is to the decided disadvantage of Boz. It must be remembered, however, that at this time Jean Paul was at the height of his literary vogue, so that a comparison from the standpoint of Mundt and his contemporaries was in itself most flattering to Dickens. "Vergleicht man ihn mit einem deutschen Dichter, mit dem er in der humoristischen Darstellung des volkstümlichen Kleinlebens einige Verwandtschaft behaupten kann, mit Jean Paul, so muss Boz freilich dagegen arm erscheinen, und hat nicht diesen grossen und unerschöpflichen Springquell des Gemütsund Gedankenlebens in sich. Boz hat auch, wie Jean Paul, seine stereotypen humoristischen Charaktere, in welche sich der Dichter selbst so hineingelebt hat, dass sie in seinen verschiedenen Werken immer wiederkehren müssen und gewissermassen die poetische Familie des Dichters abgeben. Pickwick und Master Humphrey sind ohne Zweifel Gestalten des köstlichsten und gemütlichsten Humors, die auf eine nicht gewöhnliche Lebensdauer in der Literatur Anspruch haben. Auch in ernsten psychologischen Schilderungen ist Boz glücklich, und weiss hier oft sehr ergreifende Töne anzuschlagen, ohne gerade Neues und Ausserordentliches zu geben." 22

Mundt gives us a rather interesting contemporary comment on Carlyle and his relations to German literature. "Neulich besuchte ich auch Herrn. T. Carlyle, den grössten Deutschgelehrten in England, auf seinem Landsitz in Chelsea, und freute mich an dieser kräftigen, derben, treuherzigen Schottennatur, die so viel Wahlverwandtes mit deutschem Wesen hat. Er hat sich in

${ }^{21}$ Geschichte der Literatur der Gegenwart, 429, 1842.

${ }^{22}$ Geschichte der Literatur der Gegenwart, 429-430, 1842. 
das Deutsche so hineingelebt, dass er kaum einen Satz in seiner Sprache vollendet, ohne ein Wort aus der unsrigen, das ihm gerade besonders bezeichnend erscheint, einzumischen. Aber seine Kenntnis der deutschen Literatur gleicht einem durcheinandergeworfenen Bücherhaufen, ohne Ordnung, Plan und Einheit, und für das, was er von ihr weiss, ist er viel zu streng und absprechend in seinen Urteilen über sie. Ich habe ihn im Verdacht, dass er der Verfasser des Artikels im Foreign Quarterly Review ist, der den Briefwechsel der Bettine mit Goethe so herbe verurteilte, denn er sprach sich mündlich nicht besser darüber gegen mich aus." ${ }_{23}$

\section{THE BRITON}

"Was mich betrifft, Louis, so bin ich ein völliger Engländer geworden . . . ich habe unserer Mrs. XX geschworen, England an den Vorurteilen der Deutschen zu rächen." ${ }_{24}$ No words could show more plainly how attractive Mundt found life in England. He had sought out the Englishman in his home, and with that Open Sesame to an analysis of his character, he finds himself at variance with many of the conclusions that his countrymen had drawn. He does not always take issue with their observations, but frequently his sympathetic interpretations of the phenomena that he has observed are diametrically opposed to those of Heine and Gutzkow and Laube. Thus, for example, the British Sabbath appalls him, but he protests against the charge of hypocrisy and cant brought against the Briton because of his Sabbath observance. Referring to the British Sabbath, he quotes rather aptly from Klopstock "Und die Stille ward stiller"25. . . His exculpation of the Briton from the charge of hypocrisy is unique for Young Germany: "Damit ist nicht gesagt, dass es in der englischen Sabbataskese irgend eine Heuchelei gebe, dieses Sonntagsgemüt der Nation ist vielmehr echt, es entspringt aus ihrem orthodoxen Character, aus ihren klimatischen Verhältnissen, aus dem Nebellícht ihrer Sonne, aus der Schwärze ihrer Häuser, und aus der son-

${ }^{23}$ Spaziergänge und Weltfahrten, 181, 1838. Refers to a review in Foreign Quarterly Review XXXII, (1835-1836) pages 347-360 of Goethe's Briefwechsel mit einem Kinde: The review is not credited to Carlyle in his Miscellaneous Essays.

${ }^{24}$ Spaziergänge und Weltfahrten, 2. Brief, 17. 1838.

${ }^{25}$ Spaziergänge und Weltfahrten, 7. Brief, 142-144, 1838. 
derbaren, trauernden Physiognomie, die hier zuweilen die Strassen haben." 25

Even the travelling Briton, whom the Continentals have seldom failed to anathematize, finds a protector in Mundt, who says: "Fern von seinem Mutterlande fühlt sich der Engländer, der das stärkste Heimatsgefühl unter allen Nationen hat, befangen, gekreuzt und in allen Dingen behindert, er wird ungeschickt und dadurch leicht verdriesslich und abstossend." ${ }^{26}$ For British home life and the Briton in his home, Mundt has only words of praise. "Man lernt jedoch in Boulogne, näher an England selbst und gewissermassen die überseeische Vorstadt von London, schon die eigene Liebenswürdigkeit des englischen Wesens einsehen, und dämpft allmählig die Vorurteile, welche die auf dem Kontinent herumreisenden Engländer gegen ihren Nationalcharakter in Umlauf gesetzt haben." ${ }^{26}$. . . And "Sie wissen, wie sehr mich das Treiben der englischen Familien in Paris angesprochen hat . . . Man muss hier entweder Familienmitglied oder Klubmitglied werden, dann kann man sich wohlbefinden; eine Mittelstufe des Lebens, wie in Paris das Café für das öffentliche und der Salon für das gesellschaftliche Begegnen ist, gibt es in London nicht." ${ }^{27}$ "Der Engländer ist nach Aussen ein wunderliches Mimosenkraut; nach Innen, in seine Herzen, seine Häuser und seine Familien hinein verbirgt er seine wahre Blüte und lebt da ein seltenes. Liebeleben." ${ }^{28}$

\footnotetext{
${ }^{26}$ Spaziergänge und Weltfahrten, 2. Brief, 25, 1838.

${ }^{27}$ Spaziergänge und Weltfahrten, 1. Brief, 13-14, 1838.

${ }^{28}$ Spaziergänge und Weltfahrten, 2. Brief, 22, 1838.
} 


\section{SUMMARY}

An adequate summary of the views held by Young Germany on Great Britain must, by virtue of the classification "Young Germany," overcome difficulties of a very real sort. The politicalliterary group of writers whose activities the Prussian ministry found subversive of the moral and political life of the community, comprehended men of such diversity of temperament and talent and even of aim, that to denominate them members of a school seems to dignify unduly the ministerial decree of 1835 which grouped them together and proscribed their literary activity. Every historian of literature comments on the ineptitude of the classification, but having registered his.comment, proceeds to treat the writers under it.

Nor is the classification merely one of convenient contemporaneity. There can be no doubt that however illogical the decree was in ascribing a conscious organization to the individuals promulgating the dangerous moral and political doctrines, it served to emphasize whatever community of interest existed among them and to give them for a time at least the status of a school.

Voicing the protests of a new age they may all be called radicals, but it needs to be remembered that their radicalism consisted chiefly in their opposition to the reactionary tendencies of a Frederick William III and a Metternich. In general they may be said to have demanded, in the field of literature, closer contact of literature with life, and in the field of politics, a constitution, freedom of the press and kindred principles of democratic government that were already to a great extent the possession of the South German States, and that were, of course, soon to become the property of all of Germany.

Beyond this it is difficult to ascribe to them anything like a common aim and program. Their attitude toward Britain is a case in point, for it does not involve a conscious effort on the part of most of them to bring themselves into relation to British phenomena. Heine and Mundt, to be sure, write "Fragmente" of their stay in Britain, but the opinions of others must be gathered largely from material whose bearing on Britain is frequently incidental. Hence their comments vary so much in intensiveness and exten- 
siveness that generalizations are more than usually hazardous. For this reason $I$ have confined myself in the following summary to a very few general topics: The Relation of Young Germany 1. to British Politics; 2. to British Literature; 3. to British Character

\section{British Politics}

For all the writers of Young Germany, British politics indicated the course and growth of political liberty. Even Börne, the most radical of the group, proves no exception. He had gone to Paris after the July Revolution to witness, as he thought, the restoration of representative government and the dawn of a new era, but he was doomed to disappointment. He found that France was prone to pendulate between monarchical absolutism and republican absolutism, and at times he despaired of the progress and ultimate victory of liberty in France. But British liberty was for him a political fact-an actual and lasting achievement of political struggles. And he finds Britain with her monarchical form of government a convenient argument with which to oppose those who charge him with advocating an ultra-radical, republican form of government.-Gutzkow speaks of Britain as a model state, in which sovereign and people have sacred and inviolable rights, and he prophesies the victorious course around the earth of the British fusion of liberty and law. Germany must, he asserts, take over "alles historisch Praktische und Solide" from Britain.-Mundt is convinced that Britain affords, by virtue of her kinship with Germany, her political liberty and the continuity of her political history, the most natural and best model for Germany to follow. On all the Young Germans, Britain's vigorous political life, her party system and parliamentary debate make a forceful impression.

Criticisms of political Britain are not infrequent.-Heine finds much to praise in Britain's political structure, but unerringly he points out its flaws and inconsistencies:-the injustices in parliamentary representation, the existence of prerogatives, political and clerical-relics of medievalism, he calls them. He sees, too, that the inauguration of political reform in Britain is determined not by broad principles, but by necessity and expediency; and, lover of abstract liberty that he is, he would find little to praise in what Mundt terms the guiding principle of British history, 
viz., conservative progress, - or in the later words in praise of Britain:

Where freedom broadens slowly down

From precedent to precedent.

The severity of British criminal procedure elicits extensive criticism from both Gutzkow and Heine; but on the whole the admiration for most of the features of Britain's internal political life is unfeigned and intense.

Britain in her foreign relations is variously interpreted. Börne looks forward on one occasion to a British alliance with France against Germany, not without pleasure, for it means to him the conflict of democratic with aristocratic principles. Mundt is flattered by the signs of friendship of Britain for Germany, but for Heine these signs are indications of Germany's weakness, for he finds that Britain is ruthlessly and relentlessly brutal in her foreign relations, that she pursues an egotistic, selfish course in world affairs, seeks the friendship of the weak and cr ushes the strong. Britain is thus for him "Albion perfide," and he foresees a struggle between his fatherland and Britain, when Germany will have forfeited her friendship by becoming a rival power.

\section{British Literature}

There is no disposition on the part of the Young Germans to exalt unduly the place of British literature, to repeat, for example, after the manner of Lessing, a disparagement of French literature to the advantage of British. There is, however, ample evidence to show that most of the Young Germans regarded British literature highly, and that they looked upon its past glory as well as its contemporary high standing as the natural result of the interaction of life and letters in Britain. In the words of Wienbarg, the father of Young German aesthetics, the postulates of the life of the spirit are "Nationalgefühl, gemeinsame Zwecke, gemeinsames Leben, öffentliches Leben;" and the temper of a Metternich was not conducive to the development of these necessary presuppositions of the artistic life. Hence they attributed the weakness of contemporary German literature to the absence of a vigorous political life in Germany, and they tried to explain the general excellence of Britain's writers by her political background.

Thus in the drama, Shakespeare, although for Heine a genius without a home, belonging to no particular race or time, rests 
for most of the Young Germans firmly on the political background of Elizabethan England. Börne and Gutzkow particularly find the superiority of the English drama dependent entirely on the broad, vigorous, public life of Britain, and they are convinced that until Germany has a background of political liberty for her literature the characters of her dramatists must fail to create the illusion of life.

In the field of the lyric, all the Young Germans unite in extravagant praise of Byron. In Gutzkow alone is there an admixture of criticism. Byron was looked upon as the incarnation of the political strivings of the time. If he was vague, in specific aims, the Young Germans were no less vague. Writers of prose though they were (with the exception of Heine), and advocates of prose as the more natural medium for the expression of their times, they found that no one had embodied better the spirit of the age than Byron.

Their admiration of Byron is convincing proof that the Young Germans had no serious quarrel with a romanticism that did not hold aloof from the life of the times. It was against the romantic extravagances of a Tieck that they protested. A romantic novelist like Scott found most of them ardent admirers. It is true that Wienbarg and Mundt object to the genre, historical novel, the "hybrid creation" which does violence to both history and poetry, and Wienbarg pleads for a novel of the times. But the praise of Scott by Heine, Laube and Gutzkow is given unstintedly. They find Scott able to portray life realistically, and they attribute his pre-eminence in the field of the novel to the fact that he was a Briton.

\section{The British Character}

The Young German admires particularly in the British character its ability to deal with situations without first searching for underlying philosophic principles and thus detaching them from the field of action. $\mathrm{He}$ is lost in admiration of the seriousness, the determination and persistence of the Briton in the pursuit of his ends, and although at times he finds him bold and selfish in the pursuit of these ends, on the whole he is thoroughly envious of his efficiency in the realm of the practical. He attributes a certain Charakterfestigkeit to him that has ensured for his institutions stability and power. And finally he concedes a latent 
gigantic potentiality to the individual Briton that is likely to burst the bonds of the narrow conventions and customs of his country in such transcendent geniuses as Shakespeare, Byron or Shelley.

These same narrow customs and conventions, however, furnish the theme for the most adverse comment from Heine, Gutzkow, and Laube. They find the Briton in his observance of them prudish, hypocritical, "borniert"-an arch-philistine. And personally the individual Briton is singularly unattractive to them. He is surly, materialistic, heartless,-or in the picturesque phraseology that Heine applies to England: "Wie steifleinen, wie hausbacken, wie selbstsüchtig, wie eng, wie englisch." Heine and Laube are particularly caustic in their attacks. Gutzkow, Börne and Wienbarg share the conventional opinion of the Briton prevalent on the continent then and since. Mundt alone dissents. But if Mundt finds no indication of hypocrisy or cant in the social and religious life of the Briton, and finds him in addition not uncongenial, he stands so much alone as to accentuate the more the condemnatory judgments of the others on this phase of the Briton's character. 


\section{CONCLUSION}

This investigation has shown, I believe, that Britain occupied a larger place in the Young German world of thought than is usually ascribed to her. The frequency and character of the passages quoted from the years 1834-1838, and the publication of such books as Gutzkow's "Bulwer und seine Zeitgenossen," 1837, and Mundt's "Spaziergänge und Weltfahrten," 1838, show that there was a certain concentration of interest on Britain and things British during the particularly important years in the history of the Young German movement. Students of Young Germany have been prone to over-emphasize the relation of Young Germany to France. The material gathered in this investigation will, I believe, bring into greater relief than is at present the case the relation of Young Germany to Britain. 


\section{APPENDIX}

This appendix contains, in addition to the references used in the body of the dissertation, a classified list of the more important references not so used.

\section{BÖRNE}

Political Britain:

I, 311; II, 336; III, 76; V, 218; VI, 44, 398, 414; VII, 58, 276; VIII, 34, 113. English Literature (Philosophy and History included):

General: VI, 209, 414.

Bacon: VI, 414.

Byron: VI, 414; IX, 93- , 122-128-133.

Cumberland: IV, 137-140.

Fielding: I, 214.

Gibbon: VI, 414 .

Goldsmith: I, 214.

Hume: VI, 318, 414.

Milton: VI, 414; III, 386.

Newton: VI, 414.

Pope: VI, 414.

Richardson: I, 214.

Scott: IV, 337; V, 240.

Swift: I, 214.

Shakespeare: IV, 49, 195, 201, 260, 337; V, 90-116, 414; VII, 18; VIII, 261; XI, 110, 125, 134.

English Language:

VI, 256; X, 68; XI, 1.

Characteristics of the Briton:

I, 209; III, 29, 81, 91, 218; IV, 239, 276.

\section{GUTZKOW}

Political Britain:

VII, 178; VIII, 82-103, 182-233, 345-352, 368-412, 445-446; IX, 73-83, 443-444; X, 242; XII, 132, 291.

O'Connell: IX, 84-93.

Wellington: IX, 73-84.

English Literature:

General Remarks: VIII, 6; XII, 299-300.

Bulwer: VIII, Preface; XII, 156.

Byron: XII, 73, 82-85.

Goldsmith: XII, 52.

Marryat: XII, 156.

Pope: XII, 156. 
Sterne: XII, 52.

Shakespeare: XII, 82.

English Philosophy, History and Economics:

VIII, 460-462; XII, 96-97.

Gibbon: XII, 97.

Howard: VIII, 345.

Hume: VIII, 461-462.

Locke: VIII, 461.

Smith, A.: VIII, 441.

English Language:

VII, 196-197.

Characteristics of the Briton:

VIII, 82-103, 182-233, 440; IX, 73-84, 203-208, 442-443; XII, 156.

"Die Zeitgenossen" is full of allusions to Britain; pages $399-413$ are particularly noteworthy.

\section{HEINE}

Political Britain:

III, 279-280, 432-505; V, 56-62, 113, 124-132, 372; VI, 186, 203-205-207 243, 276, 328, 418 .

Brougham: III, 476-482, 483; V, 70-71; VI, 243.

Burke: VII, 288.

Canning: III, 278, 460, 463, 490; V, 68-72, 130-131; VI, 276.

Cobbett: III, 460; V, 419.

Cromwell: IV, 61, 65-67.

Fox, C. J.: III, 463; VI, 144.

Hunt, H. Leigh: III, 475.

Lowe, Hudson: III, 160-161, 452.

Peel, Robert: III, 483; VI, 370-371.

Pitt, William (Son): III, 462: VI, 151, 374.

Walpole: VI, 370-371.

Wellington: III, 278, 487, 490-494; V, 125-126, 133-134; VI, 203-204, 243; VII, 414.

Britain and Napoleon:

III, 160-161, 273-274, 448-454; V, 63. Daffis I, 302-303.

British Writers, Philosophers, Historians, Actors, etc.

Addison: V, 419.

Bacon: IV, 205.

Byron: I, 268; III, 57, 116, 305, 378; V, 419; VI, 503-504; VII, 319, 424.

Decker: V, 480.

Dodsley: V, 384.

Farquhar: VII, 388.

Garrick: V, 388.

Gibbon: IV, 420.

Hazlitt: V, 381; VII, 107-108.

Heywood: V, 480.

Hume: III, 228.

Jameson: V, 459 . 
Johnson: V, 388, 419.

Kean: III, 297-298; 457; IV, 527-528.

Locke: IV, 209.

Lumley: VI, 101.

Marlow: V, 480; VI, 502.

Middleton: V, 436 .

Milton: VII, 134.

Newton: IV, 212.

Ossian: III, 24; VII, 190.

Owen: VI, 430.

Percy: V, 273.

Prynne: IV, 520; V, 373.

Richardson: VI, 462; VII, 314-315.

Scott: III, 115-116; 228, 445, 448-454, 496; VII, 314-315, 360.

Shakespeare: III, 359; IV, 335, 526; V, 282, 289-290, 371-490; VI, 461;

VII, 52-53, 160-162, 164, 413, 429, 469.

Shelley: III, 305.

Sidney: VII, 134.

English Language:

IV, 68, 531-533.

Church of England:

III, 419, 497; IV, 399.

Stage:

IV, 530 ; VII, 228, 316.

\section{LAUBE}

\section{Political Britain:}

I, 287; 380-381; IV, 52; V, 188; 308-309; VII, 253-262.

M. C.* II, 231.

Lord Brougham: I, 130.

Canning: VI, 98.

Cromwell: V, 188; VI, 173.

English Literature:

General remarks: II, 128-129; M. C. II, 361-362, 365, 402.

Bulwer: M. C. II, 311, 355-379.

Byron: II, 371; VI, 98; VII, 258, 261; VIII, 356-367; M. C. II, 357-358.

Lord Chatham: M. C. II, 23-24.

Dickens: I, 358.

Gibbon: VII, 261.

Johnson, Samuel: M. C. II, 371.

Moore, Thomas: VIII, 366.

Scott: I, 251; M. C. II, 161-162; 358-359, 384-386.

Shakespeare: I, 94; 104-105; VII, 258, 260; VIII, 357-358.

Shelley: M. C. II, 371; VII, 258-260.

Sheridan: M. C. II, 371.

Wordsworth: M. C. II, 371.

English Language:

M. C. II, 229-230. 
Characteristics of the Briton:

II, 365; IV, 49, 128, 194-195; V, 188, 308-309; VII, 253-262; VIII, 357-358, 361, 366; M. C. I, 257.

* M. C. $=$ Moderne Charakteristiken.

\section{MUNDT}

\section{Political Britain:}

Spaziergänge und Weltfahrten 5-6, 20, 124-127, 133, 136, 141, 273.

English Literature:

In "Geschichte der Literatur der Gegenwart" the following writers are discussed in the following order: cf. index:

Scott

Burns

Cowper

Wordsworth

Coleridge

Byron

Shelley

Moore

Scott

Bulwer

Morier

$\mathrm{Boz}$

Carlyle: Spaziergänge und Weltfahrten 181-182.

Shakespeare: Moderne Aesthetik 141, 256. Spaziergänge und Weltfahrten 133.

Sterne: Aesthetik 141.

Swift: Aesthetik 141.

English Language:

Spaziergänge und Weltfahrten 34-36.

Stage:

Macready: Spaziergänge und Weltfahrten 50.

Characteristics of the Briton:

Spaziergänge und Weltfahrten 4, 13-14, 22, 25, 117, 141, 144.

Moderne Aesthetik 141, 162.

Charaktere und Situationen II, 321.

\section{WIENBARG}

Political Britain:

Wanderungen durch den Tierkreis 131.

English Literature:

Aesthetische Feldzüge 209, 248.

Bulwer: Wanderungen durch den Tierkreis 252.

Byron: Aesthetische Feldzüge 139, 269, 275, 277-280, 288-289 Wanderungen durch den Tierkreis 166-167, 252.

Scott: Aesthetische Feldzüge 209-210, 251.

Wanderungen durch den Tierkreis 245, 252.

Shakespeare: Aesthetische Feldzüge 82-83, 143-144. 
Swift: Aesthetische Feldzüge 288-289.

Characteristics of the Briton:

Aesthetische Feldzüge 63-64.

Wanderungen durch den Tierkreis 166-167.

\section{THE PERIODICALS OF YOUNG GERMANY}

Dioskuren für Wissenschaft und Kunst, edited by Theodor Mundt.

Literarischer Zodiacus, edited by Theodor Mundt.

Deutsche Revue, edited by K. Gutzkow and Ludolf Wienbarg.

Phönix, edited by Ed. Duller (available only for the year 1837)

It was my original intention to include a chapter on the attitude of the periodicals of Young Germany toward Britain and the British. I have abandoned it for the present for the following reasons: 1. I have been unable to secure a really representative group of journals. 2. The journals to which I have had access offered, with the exception of Dioskuren (in two articles, one "Tableau der deutschen Bühne," by Hermann Marggraff, and the other "Des Knaben Liebe und Missgeschick," Novelle by E. Willkomm . . . a story of Byron based on Thomas Moore), nothing of importance. The conclusion that Britain played an insignificant part in the periodicals of Young Germany is not quite justified from this data. Reference to that monument of German scholarship and industry, Houben's Bibliographisches Repertorium, III, in its "Sachregister," reveals a very large number of articles and comments on Britain in "Phönix." Phönix was a journal, appearing daily, and hence provides a splendid background for a story of the daily life and the trials and struggles of Young Germany. However, I have had access only to the issues for the year 1837, and they are not characteristically Young German, for to quote the Bibliographisches Repertorium, "Mit dem Ausscheiden Gutzkows aus der Redaktion verlor der Phönix seine programmatische Bedeutung." Gutzkow collaborated with Duller from February until August, 1835, and it is these issues that are really the sine qua non for a study of Britain in Young German periodicals. When I have access to the Phönix of 1835, I hope to fill the lacuna in my present investigation. 


\section{BIBLIOGRAPHY}

Bloesch, H.: Das junge Deutschland in seinen Beziehungen zu Frankreich.
Bern, 1903.

Börne, Ludwig: Gesammelte Schriften. Hamburg, 1862.12 Bde.

Brandes, G.: Main Currents in Nineteenth Century Literature, Vol. VI.

Deutsche Revue - edited by $\mathbf{K}$. Gutzkow and Ludolf Wienbarg.

Dioskuren für Wissenschaft und Kunst - edited by Theodor Mundt. Draeger, Otto: Theodor Mundt und seine Beziehungen zum Jungen Deutsch-
land. Marburg, 1909.

Dresch, J.: Gutzkow et la Jeune Allemagne. Paris, 1904.

Geiger, L.: Das junge Deutschland und die preussische Zensur. Berlin, 1900.

Gutzkow, Karl: Gesammelte Werke, 2te Auflage. Jena o. J. 12 Bde.

Rückblicke auf mein Leben. Berlin, 1875 . Heine, Heinrich: Sämtliche Werke. Herausgegeben von Ernst Elster. Leip-
zig und Wien o. J. 7 Bde.

Heine-Briefe, hrsg. von H. Daffis, Berlin, 1906.
Holzmann, Michael: Ludwig Börne, Sein Leben und sein Wirken. Berlin,
1888.

Aus dem Lager der Goethe-Gegner. Mit einem Anhange: Ungedrucktes von und an Börne. Berlin,
1904. Houben, H.: Bibliographisches Repertorium III. Zeitschriften des jungen
Deutschlands.

Jungdeutscher Sturm und Drang. Ergebnisse und Studien.

Leipzig, 1911.

Laube. Allgemeine Deutsche Biographie 51. Bd. 1906.

Laube, Heinrich: Gesammelte Werke. Wien 1875-1882. 16 Bde.

Geschichte der deutschen Literatur. Stuttgart 1839-1840.

Moderne Charakteristiken. Berlin, 1835. 2 Bde.

Politische Briefe. Leipzig, 1833.
Literarischer Zodiacus - edited by Theodor Mundt.

Lublinski, S.: Literatur und Gesellschaft im neunzehnten Jahrhundert. Ber-
\[ \text { lin, } 1903 . \]

Melchior, F.: Heines Verhältnis zu Lord Byron. Berlin, 1903.

Meyer, R. M.: Gestalten und Probleme. Berlin, 1905.

Menzel, Wolfgang: Die deutsche Literatur. Stuttgart, 1836.

Mundt, Theodor: Aesthetik. Die Idee der Schönheit und des Kunstwerkes im Lichte unserer Zeit. Berlin, 1845.

Charaktere und Situationen. Wismar und Leipzig, 1837.

Die Kunst der Deutschen Prosa. Berlin, 1837.

Geschichte der Gesellschaft. Berlin, 1844.

Geschichte der Literatur der· Gegenwart. Berlin, 1842.

Kritische Wälder. Leipzig, 1833.

Madonna. Unterhaltungen mit einer Heiligen. Leipzig, 
Spaziergänge und Weltfahrten. Altona, 1838-1839.

Völkerschau auf Reisen. I. Band, Stuttgart, 1840.

Noé, Adolf Carl von: Das junge Deutschland und Goethe. Chicago, 1910.

Ochsenbein, W.: Die Aufnahme Lord Byrons in Deutschland und sein Einfluss auf den jungen Heine. Bern, 1905.

Prölss, J.: Das Junge Deutschland. Stuttgart, 1892.

Phönix - edited by Ed. Duller (only the year 1837).

Prutz, R.: Die deutsche Literatur der Gegenwart. 1848 bis 1858. Leipzig, 1860.

Schweizer, V.: Ludolf Wienbarg. Beiträge zu einer jungdeutschen Aesthetik. Leipzig, 1898.

Strodtmann, Adolf: Heines Leben und Werke. Hamburg, 1884.

Weilern, Alexander von: Laube und Shakespeare. Shakespeare Jahrbuch 43. Theaterkritiken und dramaturgische Aufsätze, in Schriften der Gesellschaft für Theatergeschichte, 7 , und 8 .

Wienbarg, Ludolf: Aesthetische Feldzüge. Dem jungen Deutschland gewidmet. Hamburg, 1834.

Wanderungen durch den Tierkreis. Hamburg, 1835.

Zur neuesten Literatur. Mannheim, 1835. 



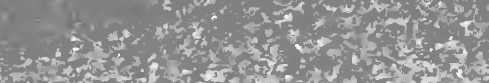

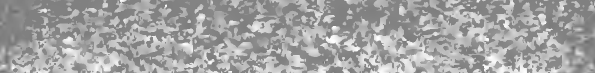

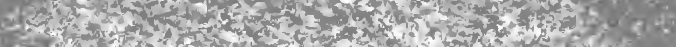

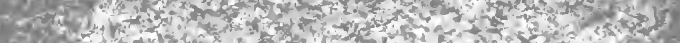

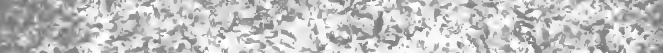

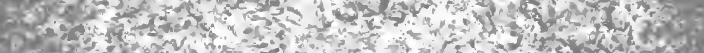

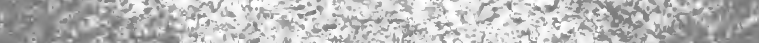

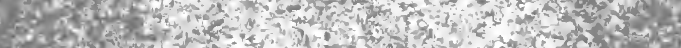

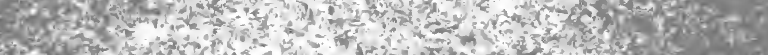

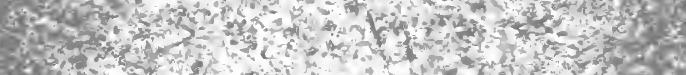
Hex

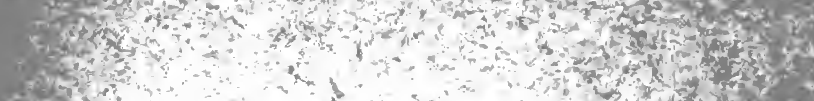

$x_{2}=2$

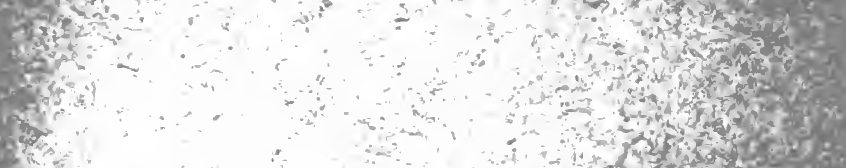

然,

and

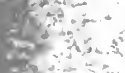

(a)

16 .

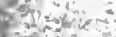

Nece

$8 x^{2}+3$

cing:

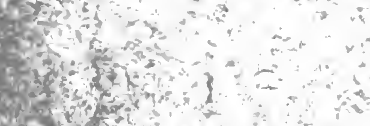

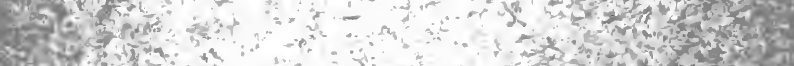

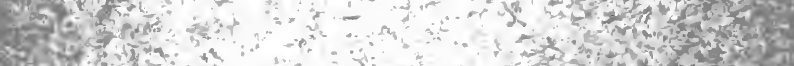

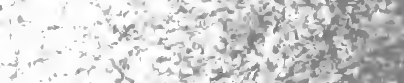

ir

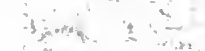

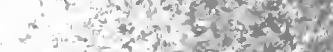

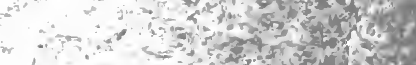

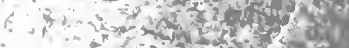

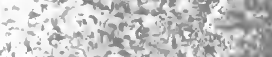

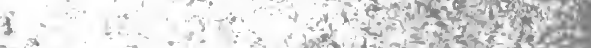

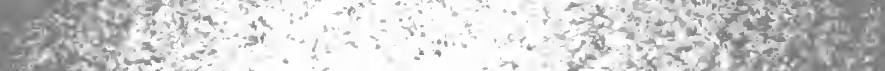
a.t.

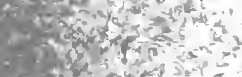

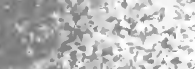

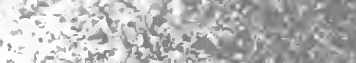

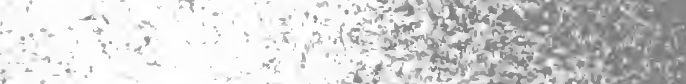

1.

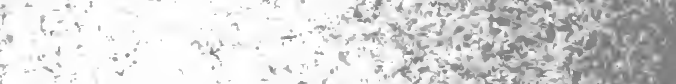

and

and

कासे

cofres

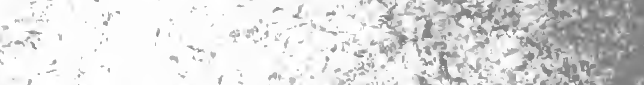

$20 \cos ^{2}+x^{2}+x^{2}$

$203 x^{2}+x^{2}+x^{2}$

is $x^{2}+x^{2}+1=$

Sother

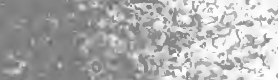

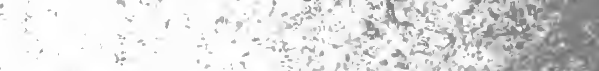

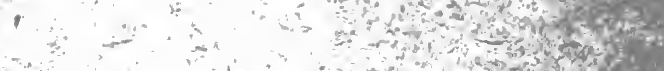

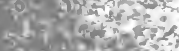

$\operatorname{los}_{1}$

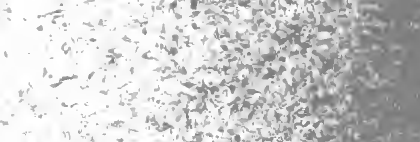

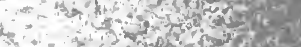

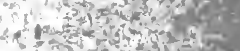

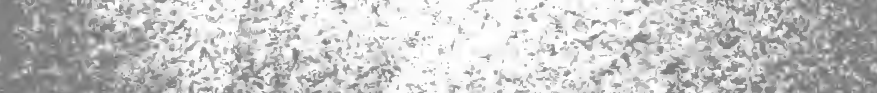

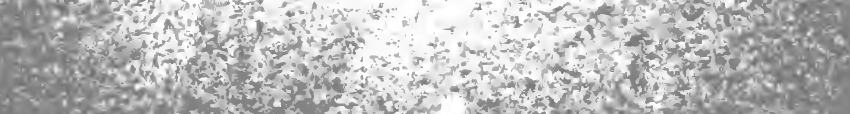

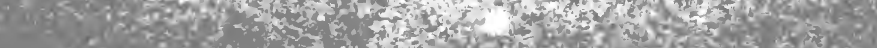

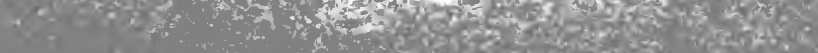




\section{DAY USE}

RETURN TO DESK FROM WHICH BORROWED

\section{LOAN DEPT.}

This book is due on the last date stamped below, or on the date to which renewed.

Renewed books are subject to immediate recall.

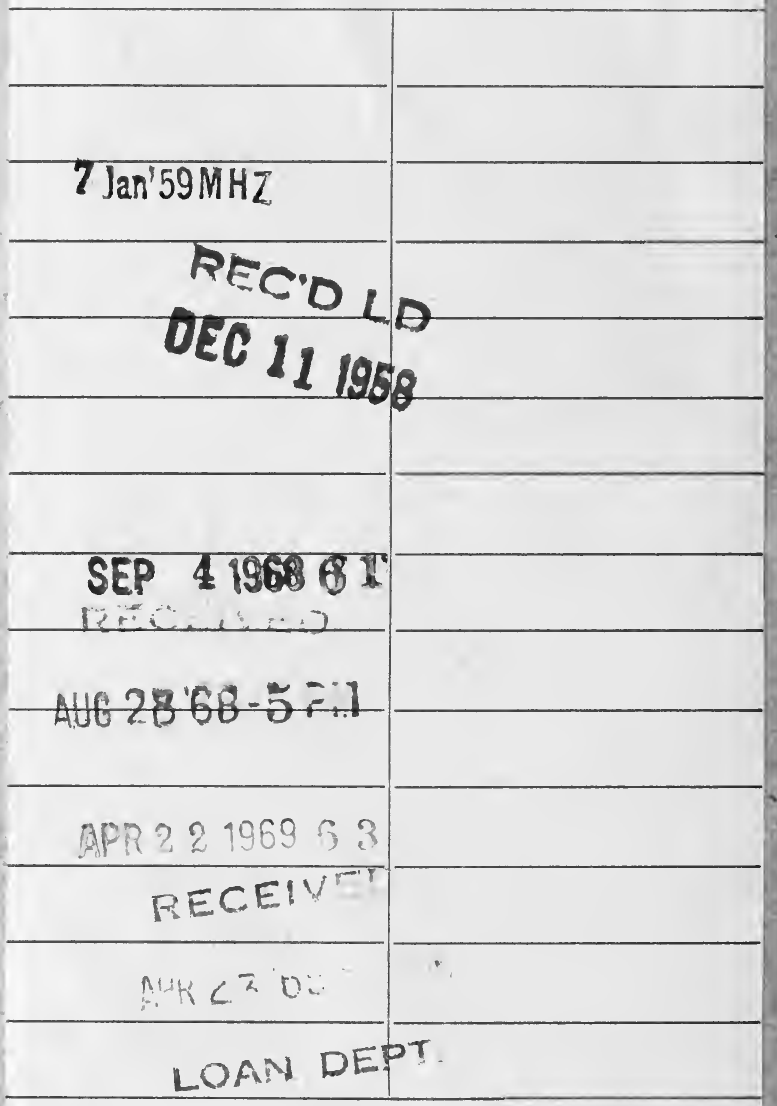

LD 21A-50m-9,'58

(6889s10) $476 \mathrm{~B}$

General Library

University of California

Berkeley 


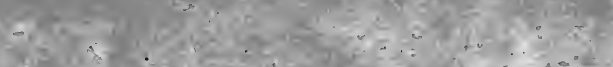

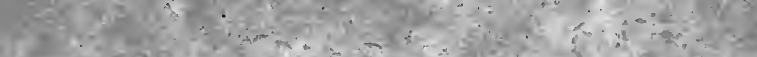

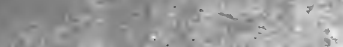

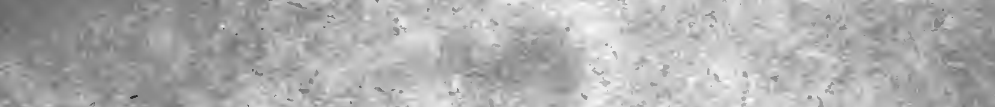

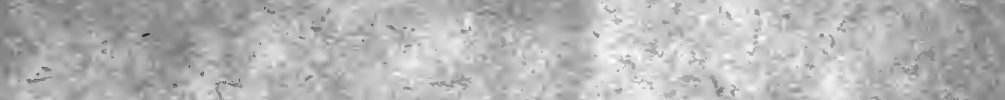

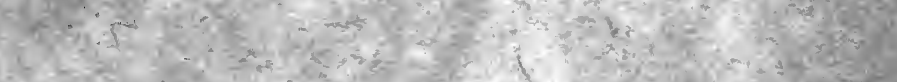

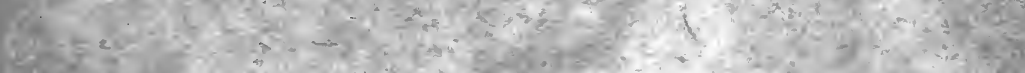

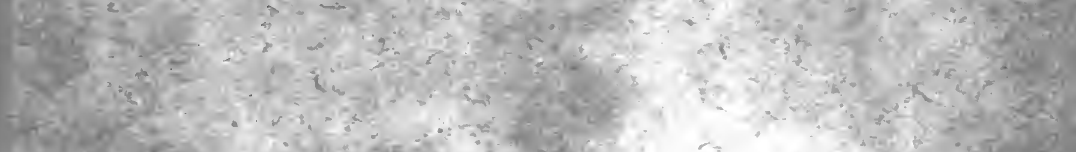

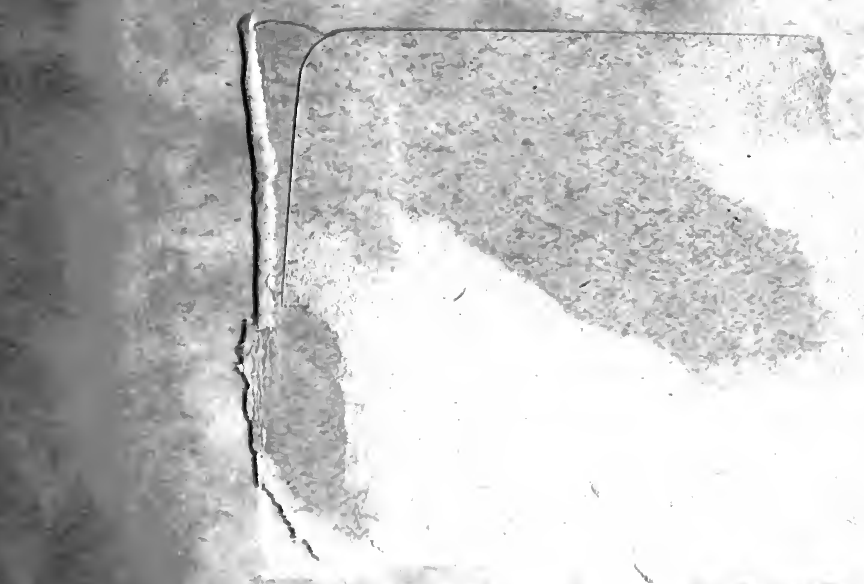

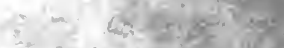

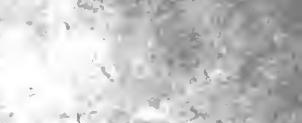

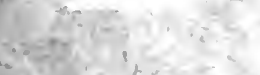

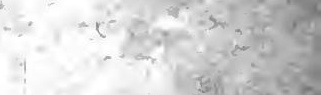

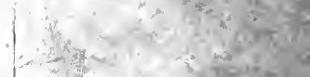

2.

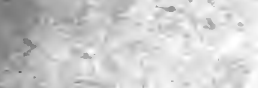

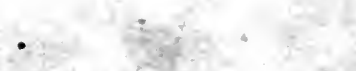

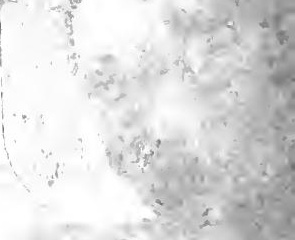

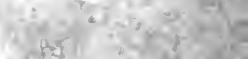

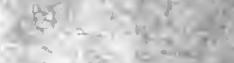

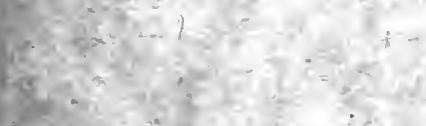

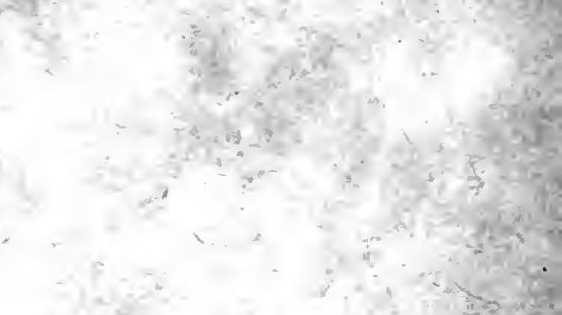

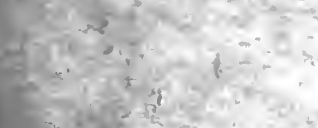

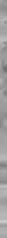


